\title{
New benthopelagic bradfordian calanoids (Crustacea: Copepoda) from the Pacific Ocean with comments on generic relationships
}

\author{
E.L. Markhaseva' ${ }^{1}$ Frank D. Ferrari ${ }^{2}$ \\ ${ }^{1}$ Russian Academy of Sciences, Zoological Institute; Universitetskaya nab. 1, 199034, St. Petersburg \\ Russia.e-mail: copepoda@zin.ru \\ ${ }^{2}$ Department of Invertebrate Zoology (MRC 534); National Museum of Natural History; Smithso- \\ nian Institution; Washington D.C. 20560 U.S.A. e-mail: Ferrari.Frank@MSC.SI.EDU
}

ABSTRACT: Three new bradfordian genera, and Rythabis heptneri sp.n. and R. schulzi sp.n. are described. Brodskius gen.n. has a narrow mandibular gnathobase with 2 distinct incisions separating groups of teeth, maxilla 1 with 1 long, thick and heavily setulated seta on proximal basal endite and 2 such setae on distal basal endite plus endopod, and setae on the distal basal endite of maxilla 1 inseparable from those of endopod. The new genus includes species formerly known as Amallothrix robustipes Grice, Hulsemann, 1965 and Xanthocalanus paululus Park, 1970, and B. benthopelagicus sp.n. and B. confusus sp.n., the latter proposed for the paratypes of Xanthocalanus paraincertus Grice, Hulsemann, 1965 which are not conspecific with the holotype. An unnamed male of Brodskius is also described. Xanthocalanus hispidus Grice, Hulsemann, 1967 is not a synonym of B. paululus.

Byrathis gen.n., has the proximal 2 terminal setae on praecoxal endite of maxilla 1 curved proximally, and includes Xanthocalanus macrocephalon Grice, Hulsemann, 1970, B. volcani sp.n., and B. laurenae sp.n.; a poorly-preserved, unnamed female of Byrathis also is described. Omorius gen.n. with the $3^{\text {rd }}$ and $4^{\text {th }}$ setae on the praecoxal endite of maxilla 1 thin and slightly curved is established for Omorius atypicus sp.n. Indistinctly separated groups of setae of the praecoxal endites of the maxilliped is a synapomorphy of Rythabis.

Evolutionary relationships of the new genera to several known bradfordian genera are inferred from an initial loss of one or two setae on the distal praecoxal endite of the maxilliped followed by transformations of sclerotized setae on all praecoxal endites of the maxilliped, and the loss of setae and arthrodial membranes to the exopod of antenna 2. Different pelagic or benthopelagic ancestors to the genera comprising both Phaennidae and Scolecitrichidae suggest these pelagic families are not their own closest relatives. Adaptation to detritivory appears to have resulted in the significant morphological variability of bradfordian calanoid copepods.

KEYWORDS: bradfordian copepods, new species, sensory setae, evolutionary relationships.

\section{Новые каланоида «брэдфордовских» семейств (Crustacea: Copepoda) из Тихого океана с комментариями о родственных отношениях между родами}

\author{
Е.Л. Мархасева' \\ 'Зоологический институт РАН; Университетская наб. 1, 199034, Санкт-Петербург, Россия. \\ e-mail:copepoda@zin.ru
}


${ }^{2}$ Department of Invertebrate Zoology (MRC 534); National Museum of Natural History; Smithsonian Institution; Washington, D.C. 20560, U.S.A.

e-mail:Ferrari.Frank@MSC.SI.EDU

РЕЗЮМЕ: Описаны три новых рода «брэдфордовских» семейств Calanoida и новые виды: Rythabis heptneri sp.n. и R. schulzi sp.n. Отличительными чертами рода Brodskius gen.n. являются строение мандибулы и максиллы первой. Узкая гнатобаза мандибулы имеет 2 отчетливые вырезки, разделяющие группы зубцов, а максилла первая проксимальный базальный эндит с 1 длинной, толстой щетинкой, густо усаженной мелкими шипиками, и две такие же щетинки на дистальном базальном эндите слитом с эндоподитом. Из-за слияния дистального базального эндита с эндоподитом не удается проследить принадлежность вооружающих их щетинок к тому или иному членику. Новый род включает ранее известные виды Amallothrix robustipes Grice, Hulsemann, 1965, Xanthocalanus paululus Park, 1970 и новые виды B. benthopelagicus sp.n. и B. confusus sp.n. Последний вид основан для паратипов Xanthocalanus paraincertus Grice, Hulsemann, 1965, которые не идентичны его голотипу. Описан, но не отнесен пока ни к одному из видов рода Brodskius, самец этого рода. Xanthocalanus hispidis Grice, Hulsemann, 1967 не является синонимом $B$. paululus.

Для рода Byrathis gen.n. характерны 2 терминальные щетинки прекоксального эндита максиллы первой, изогнутые проксимально. Род включает Xanthocalanus macrocephalon Grice, Hulsemann, 1970, B. volcani sp.n. и B. laurenae sp.n., а также описанную, но не отнесенную ни к одному из видов рода самку. Новый род Omorius gen.n. отличается тонкими, слегка изогнутыми третьей и четвертой щетинками прекоксального эндита максиллы первой и основан для вида Omorius atypicus sp.n. Неясное разделение щетинок прекоксальных лопастей синкоксы максиллипеды на группы предлагается как синапоморфия для рода Rythabis.

Обсуждаются эволюционные связи новых родов с некоторыми известными родами «брэдфордовских» семейств. В качестве отправных точек эволюционного процесса предлагаются:

- утрата одной или двух щетинок на дистальном прекоксальном эндите синкоксы максиллипеды и последующие преобразование склеротизированных щетинок на всех прекоксальных эндитах максиллипеды;

- утрата щетинок и межсегментных перегородок экзоподита антенны второй.

Отличные друг от друга предки родов, составляющих ныне семейства Phaennidae и Scolecitrichidae, пелагические (или бентопелагические), позволяют высказать предположение о том, что эти пелагические семейства не являются близкородственными. Адаптация к детритофагии, вероятно, привела к значительному морфологическому разнообразию в группе «брэдфордовских» семейств каланоид.

КЛЮЧЕВЫЕ СЛОВА: «брэдфордовские» Copepoda, новые виды, сенсорные щетинки, эволюционные взаимоотношения.

\section{Introduction}

Over the last 15 years, studies of a rather modest number of samples from water immediately above the deep-sea floor has increased the number of calanoid copepods known to science (Bradford-Grieve, 2001; Ferrari, Markhaseva, 2000a, b, c; Ohtsuka et al., 2002, 2003; Schulz, 1996, 1998; Schulz, Kwasniewsky, 2004; Schulz, Markhaseva, 2000). The mor- 
phology of these new animals often is quite different from previously described calanoids, and several new genera have been proposed (Ferrari, Markhaseva, 1996; Ferrari, Markhaseva, 2000a; Markhaseva, Dahms, 2004; Markhaseva, Schnack-Schiel, 2003; Schulz, 1996; Schulz, Beckmann, 1995; Vyshkvartzeva, 1989b). Among the families affected by the new discoveries are the bradfordian families (Scolecitrichidae Giesbrecht, 1892, Diaixidae Sars, 1902, Phaennidae Sars, 1902, Tharybidae Sars, 1902, and Parkiidae Ferrari, Markhaseva, 1996) which share two kinds of poorly-sclerotized, chemosensory setae toward the tip of maxilla 2. Studies of the anatomy of these chemosensory setae led Nishida and Ohtsuka (1997) to propose that the setae function to scan chemicals from particulate matter in the immediate vicinity of the copepods. This function suggests that the success of bradfordian calanoids has been a response to an adaptation to detritivory, in some cases driven by the exploitation of an accumulation of suspended particles in waters directly over the sea bed. The morphological diversity of these chemosensory setae among bradfordian calanoids suggests a heterogeneous environment of suspended particles with many exploitable niches. Adaptation to detritivory, then, appears to have driven the morphological variability among these calanoids in a way similar to the adaptation to herbivory or to carnivory among calanoids in shallower habitats of the oceans.

In this paper seven new species in three new genera of calanoid copepods are described, four known species are redescribed, and two specimens are described but not named. All species have segmentation and setation of the swimming legs 1-4 typical of the superfamily Clausocalanoidea, and they share chemosensory setae on the distal basal endite and ramus of maxilla 2 with the bradfordian genera. A hypothesis concerning the relationships of these new genera to the known genera of the bradfordian families is proposed based on the number and morphology of the setae on the praecoxal endites of the maxilliped, and the segmentation and setation of the exopod of antenna 2 .

\section{Methods and Terminology}

Specimens were collected from three sites: Volcano 7 (13 $23^{\prime} \mathrm{N}$; $102^{\circ} 27^{\prime} \mathrm{W}$ : dive 2146 , D8, N4 and N8; and dive 2147, D9, N4) in the eastern tropical Pacific Ocean using the submersible ALVIN sampling 1-5 $\mathrm{m}$ above seafloor depths of 2945-3100 m on November 1988 , fixed at depth of capture with glutaraldehyde (see Ferrari, Markhaseva (1996) for further details); near Kona, Hawaii (1943'N $156^{\circ} 04 \mathrm{~W}$ ) in July 6,1997 , from seawater flowing from a flexible plastic pipe, intake diameter of $1 \mathrm{~m}$ at depth of about $600 \mathrm{~m}$ and about $30 \mathrm{~m}$ from the bottom, maintained by Natural Energy Laboratory of Hawaii Authority, fixed at surface with formaldehyde (see Ferrari, Markhaseva (2000b) for further details); around hydrothermal vents along the East Pacific Rise $\left(09^{\circ}\right.$ $50^{\prime} \mathrm{N} 104^{\circ} 17^{\prime} \mathrm{W}$ ) collected by pumps, intake diameter $2.5 \mathrm{~cm}, 1 \mathrm{~m}$ or $20 \mathrm{~m}$ or $175 \mathrm{~m}$ above sea-floor depths of about 2,500 $\mathrm{m}$ in May 2000, fixed at surface with formaldehyde and retrieved by the submersible ALVIN, dive 3561 (see Mullineaux et al. (2005) for further details).

In the laboratory, specimens from all localities were preserved in $0.5 \%$ propylene phenoxytol $/ 4.5 \%$ propylene glycol $/ 95.0 \%$ de-ionized freshwater. During examination, specimens were cleared in steps through 50\% lactic acid/ $50 \%$ de-ionized freshwater to $100 \%$ lactic acid, stained by adding a solution of chlorazol black E dissolved in $70 \%$ ethanol/30\% deionized freshwater, and examined with bright-field and with differential interference optics. Drawings were made with a camera lucida. Dissected and undissected specimens are preserved in $70 \%$ ethanol $/ 30 \%$ de-ionized freshwater. Specimens are deposited in National Museum of Natural History, Smithsonian Institution, Washington, D.C. (USNM).

The body of adult calanoid copepods is described here as a cephalosome (five cephalic and anterior thoracic somites fused), five pedigers $(\mathrm{Pg})$ (the first may be fused to the cephalosome; the last two may be fused to one another), and urosome (the posterior thoracic and 4 abdominal somites with the thoracic and anteri- 
or abdominal fused in females to form a genital complex). Length of the copepod is measured from the anterior edge of the cephalosome to the posterior edge of the caudal ramus, and does not include that part of the prosome which overlaps the genital complex. Appendages are abbreviated $\mathrm{A} 1=$ antenna $1 ; \mathrm{A} 2=$ antenna $2 ; \mathrm{Mn}=$ mandible; $\mathrm{Mx} 1=$ maxilla $1 ; \mathrm{Mx} 2=\operatorname{maxilla} 2$, $\mathrm{Mxp}=$ maxilliped (anterior to posterior on cephalosome); P1-5 = swimming legs 1-5 (on pedigers); $\mathrm{CR}=$ caudal ramus. Designations of appendage segments follow Ferrari (1995) and Ferrari, Markhaseva (2000b). The coxa of the maxilliped of copepods has one endite with a group of setae (Ferrari, Ivanenko 2001); the remaining three proximal groups of setae on the calanoid syncoxa belong to three praecoxal endites. Articulating armament elements of appendages are termed setae regardless of their location, morphology or degree of rigidity. Two setae and one aesthetasc on a segment of antenna 1 are designated $2+1$; "?" indicates that a seta appears broken and only the scar at the location of attachment was observed. Setules are epicuticular extensions of a seta; denticles are epicuticular extensions of an appendage segment; spinules are epicuticular extensions of a somite. Transformed setae toward the tip of maxilla 2 and on the syncoxa of the maxilliped (bradfordian setae) show quite a degree of morphological variability (Bradford, 1973); they are divided into two groups, worm-like setae (w) and brushlike setae (b), conforming to the two kinds studied by Nishida and Ohtsuka (1997). Sclerotized setae are designated as "sc". Some setae on the posterior cephalic and first thoracic appendages of a few calanoid copepods tentatively have been assigned a chemosensory function based on transmission electron micrographs of internal structure and, in some cases, on an opening on the sclerotized tip of a seta (Friedman, Strickler, 1975, Paffenhofer, Loyd, 1999, Paffenhofer, Loyd, 2000). However, the origin of such setae on particular segment/s of these appendages has not been specified, and comparative observations with the ultrastructure of setae on other appendages have not been made. Here we continue to equate a well-sclerotized setal morphol- ogy with a mechanosensory function and a poorly-sclerotized setal morphology with a chemosensory function. Von Vaupel Klein's organ (Ferrari, Steinberg, 1993; Ferrari, 1995; Ferrari, Markhaseva, 1996) on P1 consists of the medial seta of the basis juxtaposed with sensilla, denticles, and/or pores often on a knob of the anterior face of the endopod.

Seifried (2003) has provided a nuanced analysis of how the concept of oligomerization (Dogiel, 1954) may be applied to loss of elements in a group of serially homologous elements like segments of a ramus of a limb or setae on a limb segment. The following discussion accepts that oligomerization remains a reasonable first approximation to the reduction in number of serially homologous structures such as limb segments or their setae.

Holotypes and paratypes are deposited in the National Museum of Natural History; Smithsonian Institution; Washington, D.C.

\section{Taxonomy}

\section{Brodskius gen.n.}

Diagnosis. Adult female with cephalosome separate or fused to Pg1, Pg4-5 separate. Rostrum 2 delicate filaments. Posterior corners of prosome laterally as an indented lobe. A1 of 24 articulated segments. A2 coxa and basis without setae. Mn gnathobase elongate; narrow medially with a knob on distal face; cutting edge narrow, with 2 distinct incisions separating groups of teeth. Mx1 distal basal endite fused to unsegmented $\mathrm{Ri}$, setae of distal basal endite inseparable from setae of endopod; 1 seta on proximal basal endite and 2 setae on distal basal endite + Ri long and thick with long setules. Mx2 proximal praecoxal endite with 4 sclerotized setae; both coxal endites and proximal basal endite with 1 thick seta, seta on basal endite thickest and claw-like; 5 worm-like setae with well-developed setules and 2 or 3 short brush-like setae on distal basal endite + ramus. Mxp syncoxa without seta on proximal praecoxal endite, 2 setae on middle praecoxal endite, 3 setae on distal praecoxal endite; all praecoxal setae sclerotized; coxal endite with 3 setae. P1-4 clausocalanoidean segmentation and setation. P5 3-segmented; distal segment, the exopod, with 1 medial, 1 lateral and 1 subterminal seta, and terminal unarticulated extension. Adult male similar to female except: posterior corners of prosome 
not indented; left A1 24-segmented, right A1 23 segmented; more and larger aesthetascs; gnathobase of Mn poorly-developed; Mx1 reduced in size and setation; Mxp praecoxal endites of syncoxa with $0,2,3$ sclerotized setae smaller; Von Vaupel Klein's organ of P1 without basal seta and anterior knob. P5 leg biramous, right Re 2-segmented, left Re 3-segmented; both Ri 1-segmented, right small and left one longer than Re.

Synapomorphies of Brodskius are: mandibular gnathobase narrow, with 2 distinct incisions separating groups of teeth; maxilla 1 with 1 long, thick and heavily setulated seta on proximal basal endite and 2 such setae on distal basal endite + Ri; setae of distal basal endite inseparable from those of Ri.

Character states that distinguish species of Brodskius from most bradfordian genera are: absence of an arthrodial membrane between basis and endopod of maxilla 1 (shared with some species of Pseudophaenna, Rythabis and some species of Diaixis); Ri of maxilla 1 unsegmented (shared with some species of Pseudophaenna, Rythabis and some species of Diaixis); more than 4 worm-like sensory setae on distal basal endite + ramus of maxilla 2 (shared with Byrathis gen.n., here, Omorius gen.n., here, Neoscolecithrix, Rythabis and some species of Diaixis); proximal syncoxal endite of maxilliped without a seta (shared with Undinella and Pseudophaenna).

Etymology. The genus name Brodskius honors copepodologist Konstantin Abramovich Brodsky for his insightful contributions to the systematics of calanoid copepods. Gender masculine.

Type species: Brodskius benthopelagicus sp.n. Other species included in the genus: $B$. paululus comb.n., B. robustipes comb.n. and B. confusus comb.n.

\section{Brodskius benthopelagicus sp.n.} Figs 1-5.

Specimens. Adult female holotype $1.02 \mathrm{~mm}$ (USNM \#1080961); prosome $0.86 \mathrm{~mm}$, urosome 0.16 $\mathrm{mm}$ from eastern tropical Pacific Ocean $1-5 \mathrm{~m}$ above Volcano 7, (dive 2146, D8, N8), 3022-3100 m. Paratypes: 2 females (USNM \#1080962), $0.92 \mathrm{~mm}$ (prosome $0.77 \mathrm{~mm}$, urosome $0.15 \mathrm{~mm}$ ) and $1.06 \mathrm{~mm}$ (prosome $0.87 \mathrm{~mm}$, urosome $0.19 \mathrm{~mm}$ ); collection data as for holotype.

Habitus. Total length $0.92-1.06 \mathrm{~mm}$; prosome 4.6-5.4 times longer than urosome. Cephalosome fused with $\mathrm{Pg} 1 ; \mathrm{Pg} 4$ and $\mathrm{Pg} 5$ separate (Fig. 1A-B, D). Dorsally cephalosome rounded anteriorly (Fig. 1A); posterior corners of prosome produced laterally into short indented lobe (Fig. 1B). Genital complex symmetrical, spermathecae elongate, distal part directed anteriorly (Fig. 1D).

Rostrum (Fig. 1C, E): 2 short thin filaments.
A1 (Fig. 2A-B ): 24 articulated segments with $2,6+1,2+1,2,2+1,2,2+1,4+1,1,1,2+1,1,2+1$, $1,2,1,2+1,1,1,1,2,2,2,4+1$ setae.

A2 (Fig. 2C-D): coxa without seta; basis without seta. Ri 2-segmented, proximal segment with 1 setae, distal with 14 (6 terminal and 8 sub-terminal setae). Re 7-segmented with $0,1,1,1,1,1,3$ setae.

Mn (Fig. 2E-G): gnathobase elongate, narrow medially with a knob on distal face; cutting edge narrow with 2 deep incisions among teeth; basis with 1 seta. Ri 2-segmented, proximal segment with 1 seta; distal with 9 setae. Re with 1, 1, 1, 1, 1 setae.

Mx1 (Fig. 3A): praecoxal endite with 9 terminal and 2 posterior setae. Coxal endite with 2 setae; coxal epipodite with 6 setae. Proximal basal endite with 4 setae, 1 long, thick and heavily setulated; distal basal endite fused to Ri with 10 setae total, 2 long, thick and heavily setulated. Re with 6 setae.

Mx2 (Fig. 3B-C): proximal praecoxal endite with 4 setae; distal with 3 setae. Proximal coxal endite with 3 setae, 1 thick, distal endite with 3 setae, 1 thick and 1 worm-like. Proximal basal endite with 4 setae, 1 thick and 1 worm-like. Distal basal endite + ramus with 5 worm-like setae with setules and 3 brush-like setae.

Mxp (Fig. 4A-B): praecoxal endites of syncoxa with $0,2,3$ sclerotized setae; coxal endite with 3 setae. Basis with a row of denticles proximally, 3 medial setae and 2 setae on distal endite. Ri of 5 articulated segments with $4,3,2,2+1$ lateral and 4 setae.

P1 (Fig. 4C-D): coxa without seta; basis with medial seta. Re 3-segmented, proximal with 1 lateral seta, middle with 1 medial and 1 lateral seta, distal with 3 medial, 1 terminal, 1 lateral seta; lateral seta on proximal segment exceeds the base of lateral setae of terminal segment, lateral seta on middle segment exceeds half length of lateral seta of terminal segment. Ri 1-segmented with 3 medial and 2 terminal setae; Von Vaupel Klein's organ with curved basal seta and triangular anterior knob with denticles.

P2 (Fig. 5A): coxa with medial seta; basis without seta. Re 3-segmented, proximal with 1 medial and 1 lateral seta, middle with 1 medial and 1 lateral seta, distal with 4 medial, 1 terminal and 3 lateral setae. Ri 2-segmented, proximal with 1 medial seta, distal with 2 medial, 2 terminal and 1 lateral setae; Ri2 with denticles on posterior surface.

P3 (Fig. 5B-C): coxa with medial seta; basis without seta. Re 3-segmented, proximal with 1 lateral seta, middle with 1 medial and 1 lateral seta, distal with 4 medial, 1 terminal and 3 lateral setae. Ri 3-segmented, proximal with 1 medial seta, middle with 1 medial seta, distal with 2 medial, 2 terminal and 1 lateral seta; Ri2-3 with denticles on posterior surface. 


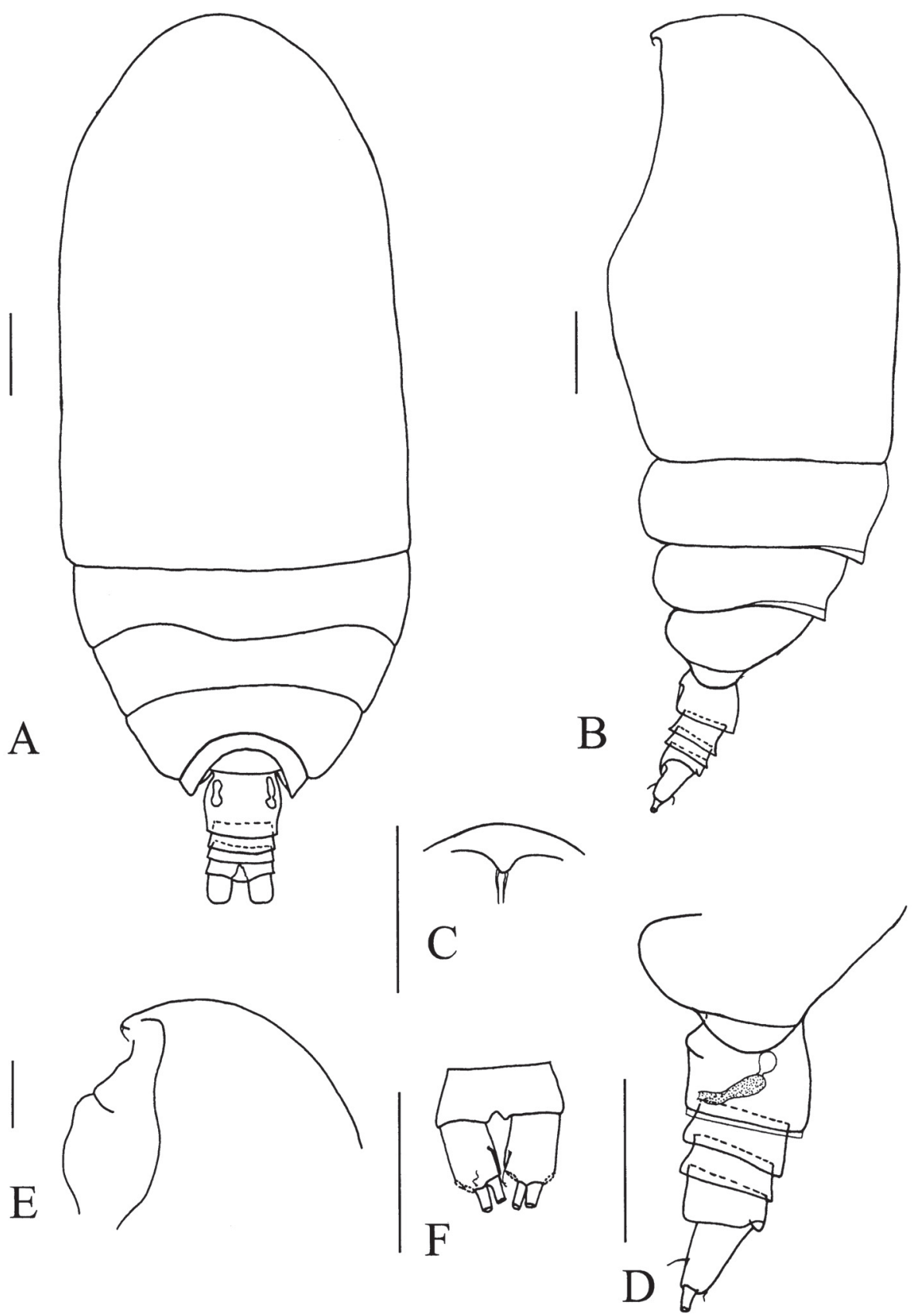

Fig. 1. Brodskius benthopelagicus gen.n., sp.n., 오

A - habitus, dorsal; B - habitus, left lateral; C - anterior cephalosome, ventral; D - posterior prosome and urosome, left lateral; E - anterior cephalosome, left lateral; F - anal segment and CR, dorsal view. C, F of holotype; A-B, DE of paratypes. Scale lines $0.1 \mathrm{~mm}$.

Рис. 1. Brodskius benthopelagicus gen.n., sp.n.,, :

A - общий вид со спины; В - общий вид слева; C - передняя часть цефалосомы с брюшной стороны; D задняя часть просомы и уросомы, вид слева; $\mathrm{E}$ - передняя часть цефалосомы слева; $\mathrm{F}$ - анальный сегмент и CR, вид со спины. C, F - голотип; A-B, D-E - паратипы. Масштаб 0,1 mm. 


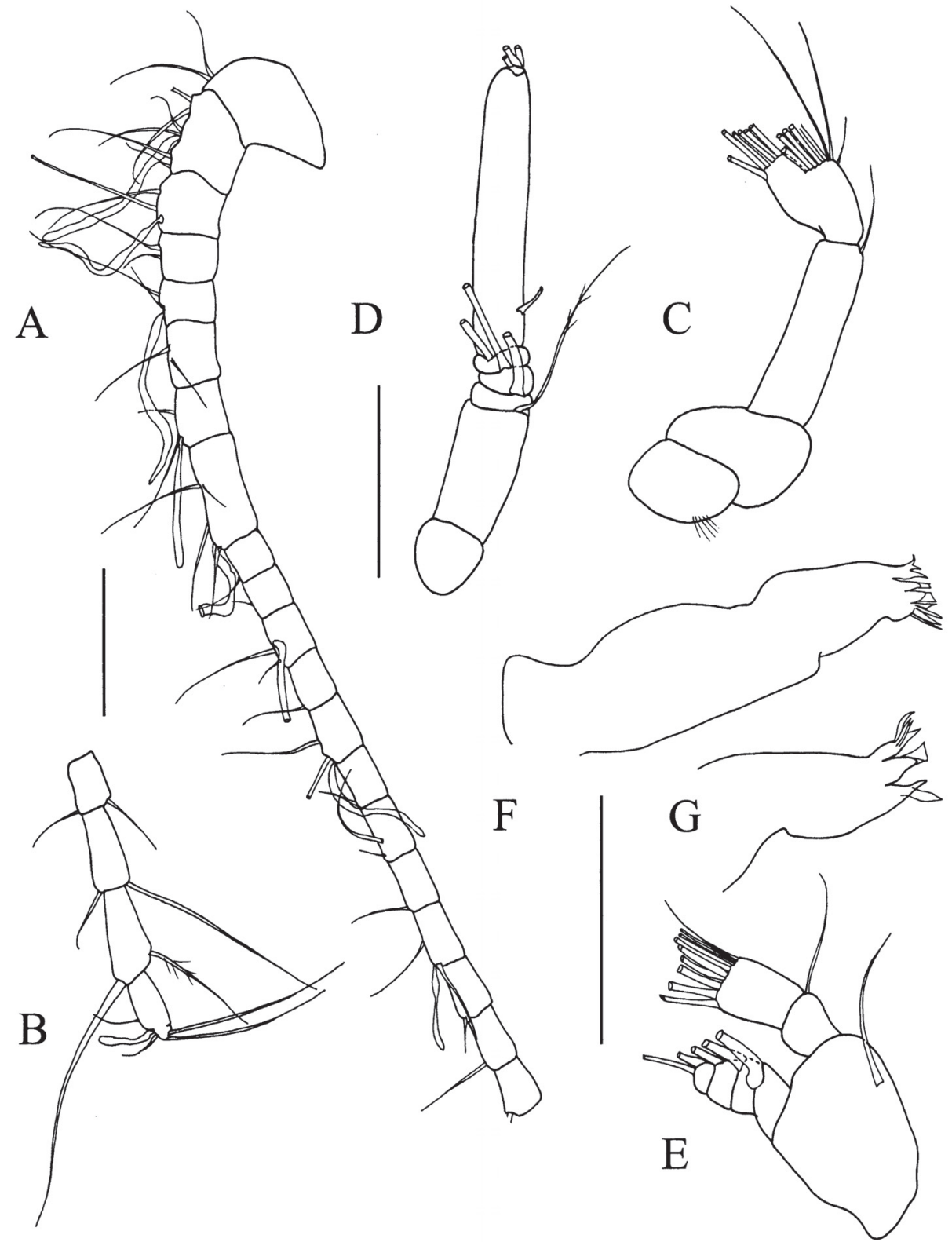

Fig. 2. Brodskius benthopelagicus gen.n., sp.n.,, :

A - antenna 1, articulating segments 1-20; B - antenna 1, articulating segments 21-24; C - antenna 2, protopod and endopod; D - antenna 2, exopod; E - mandibular palp; F - mandibular gnathobase, posterior, distal up; G - medial section of mandibular gnathobase, anterior, distal down. $\mathrm{C}-\mathrm{G}$ of holotype, A-B of paratypes. Scale lines $0.1 \mathrm{~mm}$. Рис. 2. Brodskius benthopelagicus gen.n., sp.n.,, :

А - антенна 1, свободные сегменты 1-20; В - антенна 1, свободные сегменты 21-24; C - антенна 2, протоподит и эндоподит; D - антенна 2, экзоподит; Е - щупик мандибулы; F — гнатобаза мандибулы, задняя поверхность; $\mathrm{G}$ - средняя часть гнатобазы мандибулы, передняя поверхность. $\mathrm{C}-\mathrm{G}$ - голотип, $\mathrm{A}-\mathrm{B}$ - паратип. Масштаб 0,1 мм. 

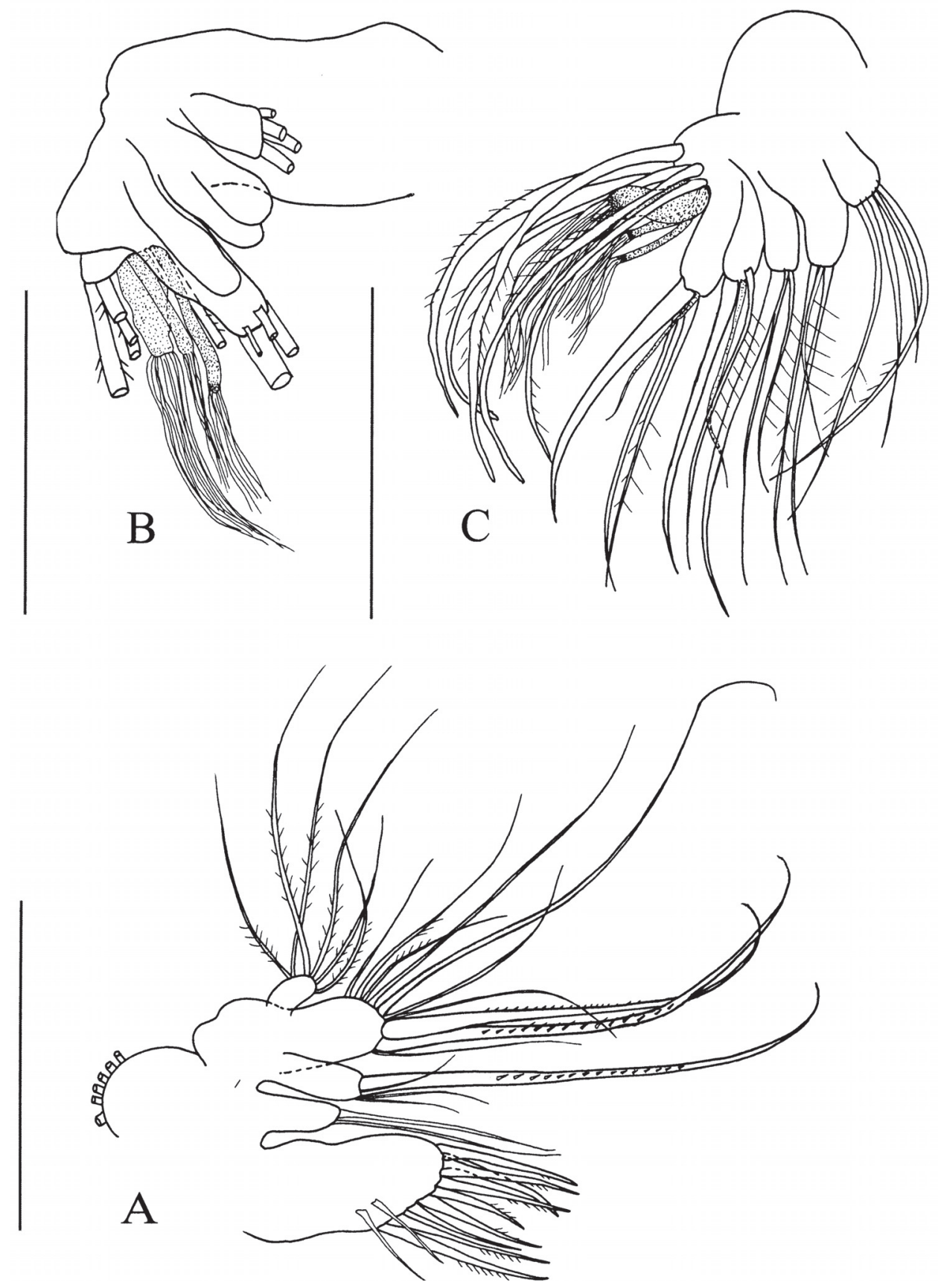

Fig. 3. Brodskius benthopelagicus gen.n., sp.n., ㅇ:

A - maxilla 1, posterior; B - maxilla 2, posterior, setation not shown; C - maxilla 2, anterior: A, C of holotype, B of paratype. Scale lines $0.1 \mathrm{~mm}$.

Pис. 3. Brodskius benthopelagicus gen.n., sp.n., ${ }^{+}$:

А - максилла 1 , задняя поверхность; В - максилла 2, задняя поверхность; С - максилла 2, передняя поверхность: А, C — голотип, В — паратип. Масштаб 0,1 мм. 


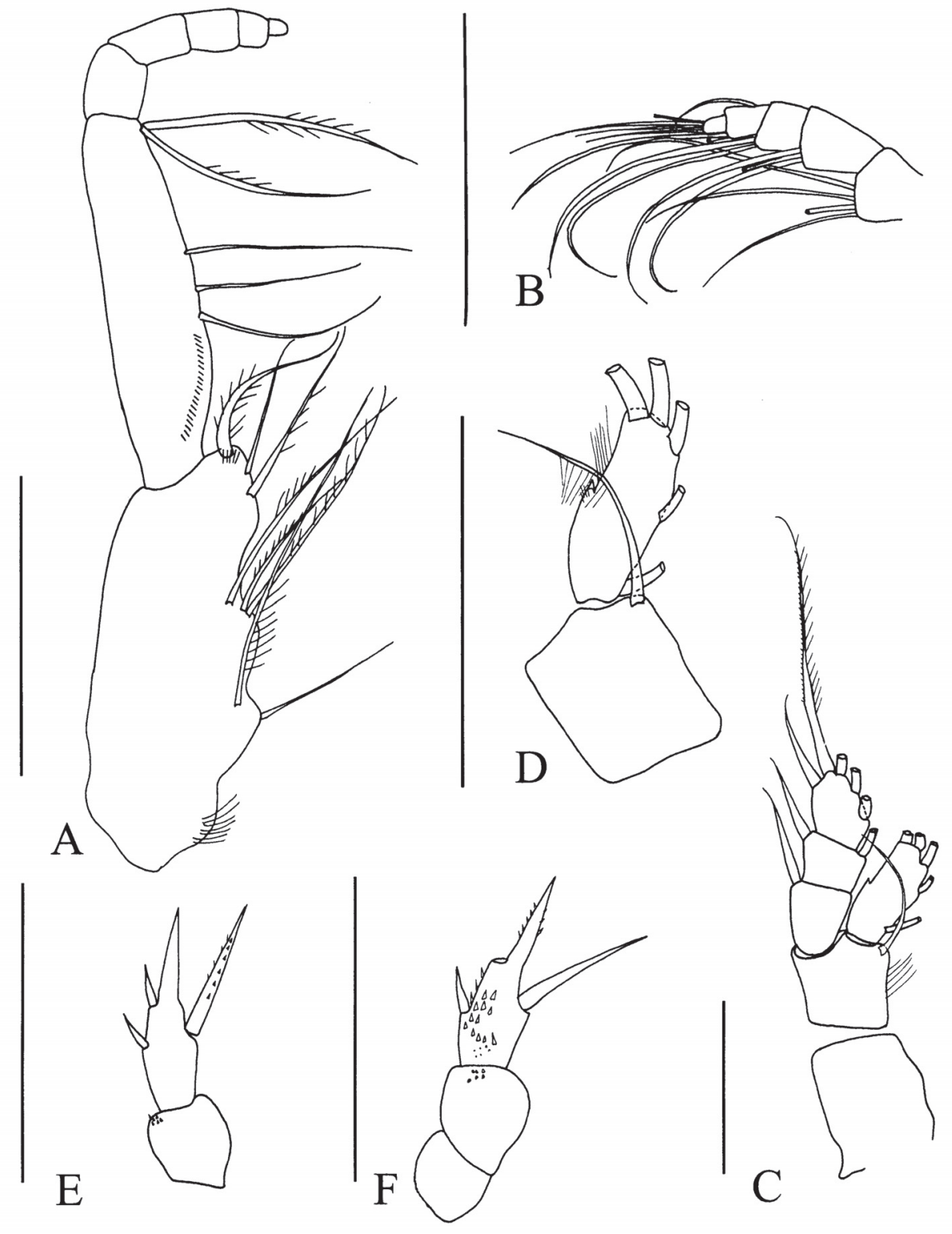

Fig. 4. Brodskius benthopelagicus gen. n., sp.n., + :

A - maxilliped, setae of endopod not drawn; B - maxilliped, endopod; C - swimming leg 1, anterior, coxa detached; D - swimming leg 1, anterior, basis and endopod; E - leg 5, posterior; F - leg 5, posterior of another paratype. A$\mathrm{B}$ of holotype, $\mathrm{C}-\mathrm{F}$ of paratypes. Scale lines $0.1 \mathrm{~mm}$.

Рис. 4. Brodskius benthopelagicus gen. n., sp.n.,, :

A - максиллипеда, щетинки эндоподита не изображены; В - максиллипеда, эндоподит; C - первая пара плавательных ног, передняя поверхность, кокса отделена; D - первая пара плавательных ног, передняя поверхность, базис и эндоподит; $\mathrm{E}$ - пятая пара ног, задняя поверхность; $\mathrm{F}$ - пятая пара ног, задняя поверхность другого паратипа. А-B - голотип, $\mathrm{C}-\mathrm{F}$ - паратип. Масштаб 0,1 мм. 

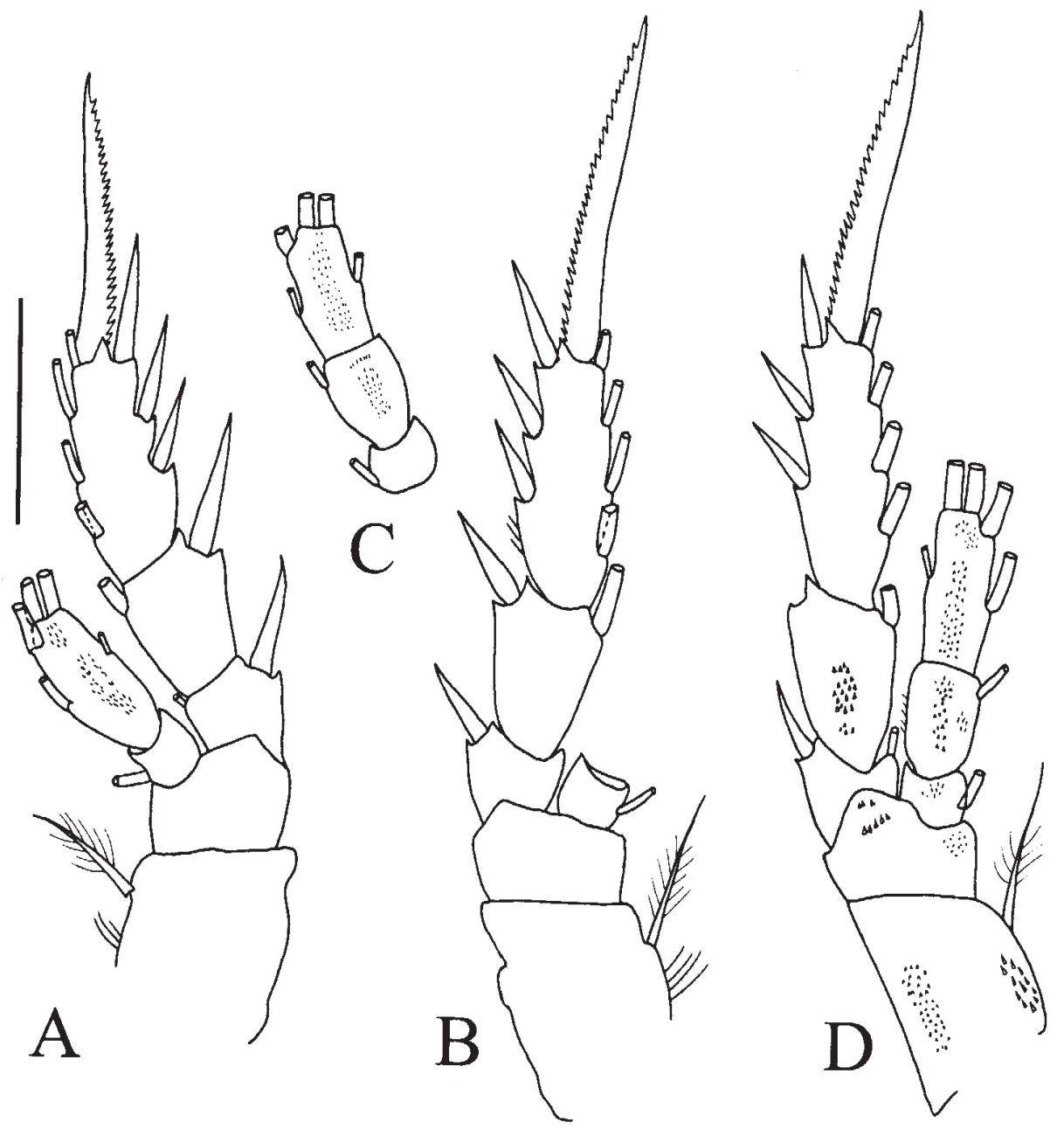

Fig. 5. Brodskius benthopelagicus gen. n., sp.n., + :

A - swimming leg 2, posterior; B - swimming leg 3, posterior, middle and distal segment of endopod not drawn; $\mathrm{C}$ - swimming leg 3 endopod, posterior; D - swimming leg 4, posterior. A of holotype, B-D of paratypes. Scale lines $0.1 \mathrm{~mm}$.

Рис. 5. Brodskius benthopelagicus gen. n., sp.n.,, :

А — вторая пара плавательных ног, задняя поверхность; В — третья пара плавательных ног, задняя поверхность, средний и дистальный сегменты эндоподита не изображены; C - третья пара плавательных ног, эндоподит, задняя поверхность; D — четвертая пара плавательных ног, задняя поверхность. А — голотип, B-D — паратипы. Масштаб 0,1 мм.

P4 (Fig. 5D): Coxa with medial seta; basis without seta. Re 3-segmented, proximal with 1 medial and 1 lateral seta, middle with 1 medial and lateral seta, distal with 4 medial, 1 terminal and 3 lateral setae. Ri 3-segmented, proximal with 1 medial seta, middle with 1 medial seta, distal with 2 medial, 2 terminal and 1 lateral seta; coxa, basis, Ri and Re2 with denticles on posterior surface.

P5 (Fig. 4E-F): 3-segmented; basis (middle segment) with posterior denticles; Re (distal seg- 


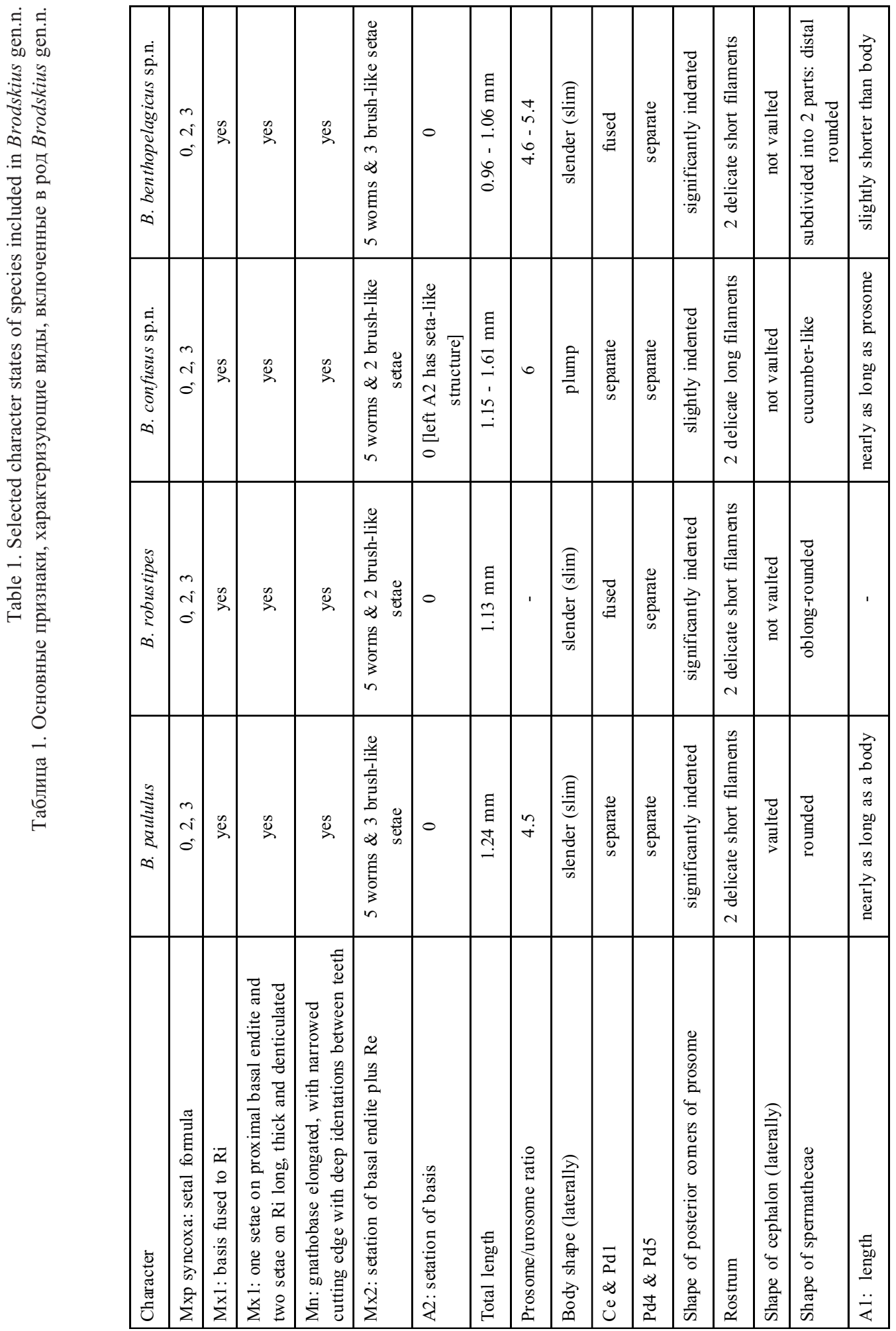




\begin{tabular}{|c|c|c|c|c|c|c|c|c|c|c|c|c|c|c|}
\hline & 0 & $\begin{array}{l}m \\
\Rightarrow \\
\Rightarrow\end{array}$ & - & - & 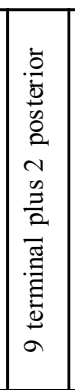 & $N$ & $\sigma$ & $\stackrel{\circ}{\simeq}$ & 0 & 0 & $\begin{array}{l}\vec{r} \\
\hat{m} \\
\dot{m} \\
\dot{m} \\
\dot{r}\end{array}$ & 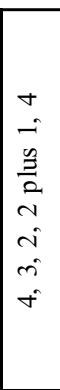 & 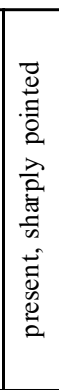 & 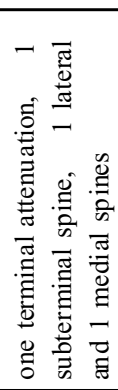 \\
\hline 5 & 0 & $\begin{array}{l}\because \\
\Rightarrow \\
\Rightarrow\end{array}$ & $N$ & $N$ & 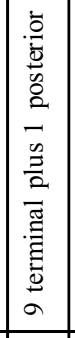 & $N$ & $\sim$ & $a$ & in & 0 & $\begin{array}{l}\vec{r} \\
\dot{m} \\
\dot{m} \\
\dot{m} \\
\dot{r}\end{array}$ & 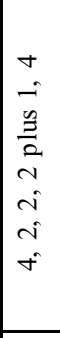 & $\mid \begin{array}{l}\overrightarrow{\vec{v}} \\
\overrightarrow{0} \\
\vec{\sigma}\end{array}$ & 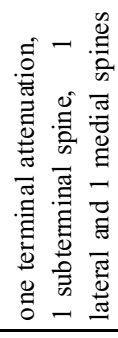 \\
\hline 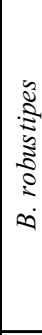 & 0 & $\begin{array}{l}\because \\
\vdots \\
\vdots\end{array}$ & - & - & 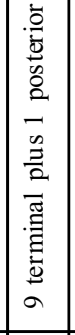 & $N$ & t & $\stackrel{\circ}{\simeq}$ & $m$ & 0 & $\begin{array}{l}\vec{r} \\
\hat{m} \\
\dot{m} \\
\dot{m} \\
\dot{r}\end{array}$ & 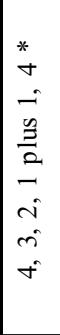 & 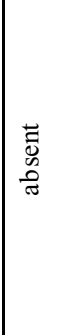 & 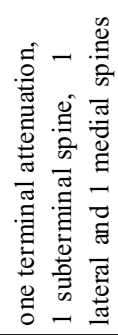 \\
\hline $\bar{\Xi}$ & 0 & $\begin{array}{l}\because \\
\vdots \\
\vdots\end{array}$ & - & - & 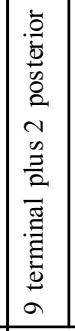 & $\sim$ & $m$ & $\begin{array}{l}\underset{\Xi}{\Xi} \\
\varrho\end{array}$ & 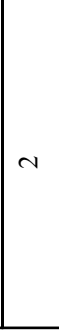 & 0 & $\begin{array}{l}\vec{r} \\
\vec{r} \\
\vec{r} \\
\vec{r}\end{array}$ & 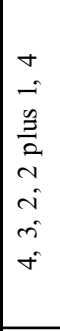 & 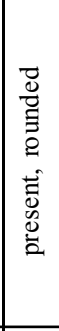 & 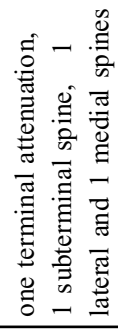 \\
\hline $\bar{E}$ & 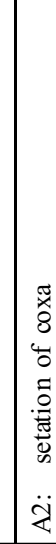 & 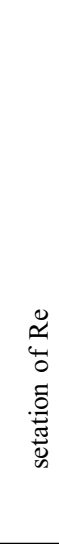 & 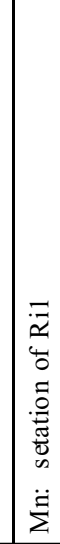 & 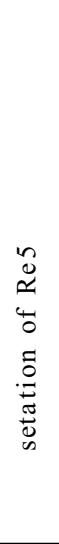 & 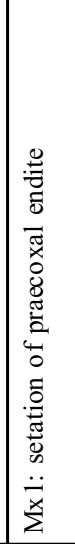 & 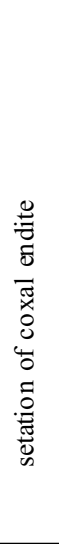 & 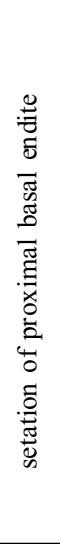 & 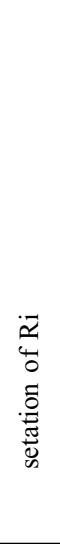 & 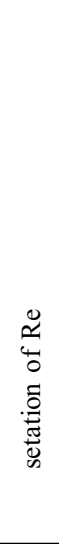 & 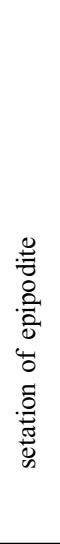 & 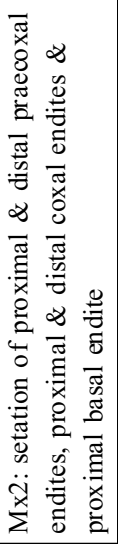 & 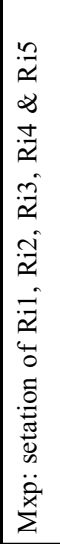 & 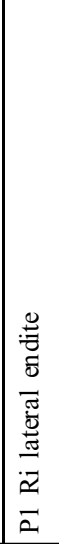 & 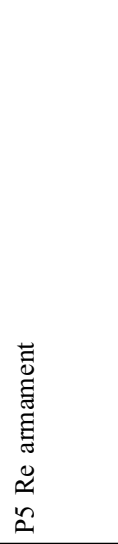 \\
\hline
\end{tabular}




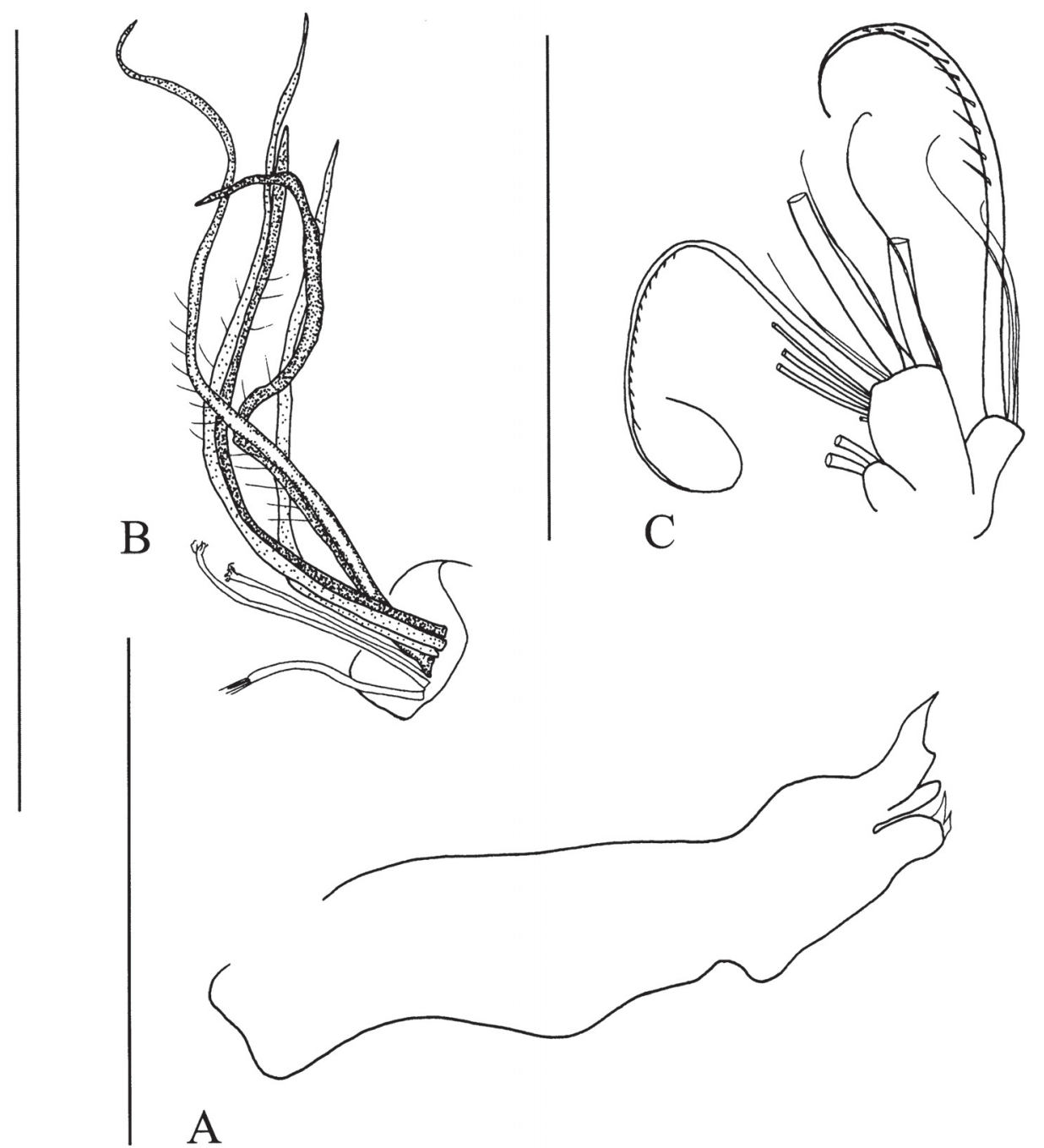

Fig. 6. Brodskius paululus (Park, 1970) comb.n.,, (holotype):

A - mandibular gnathobase, posterior, distal down; B - maxilla 2, sensory setae on distal endite of basis + ramus; $\mathrm{C}$ - maxilla 1, proximal and distal endite of basis, endopod and exopod, posterior. Scale lines $0.1 \mathrm{~mm}$.

Рис. 6. Brodskius paululus (Park, 1970) comb.n., (голотип):

А — гнатобаза мандибулы, задняя поверхность; В — максилла 2, сенсорные щетинки на дистальном базальном эндите и ветви; C — максилла 1, проксимальный и дистальный базальные эндиты, эндоподит и экзоподит, задняя поверхность. Масштаб 0,1 мм.

ment) with posterior denticles and 1 long medial, short lateral and 1 short subterminal setae, and terminal unarticulated extension.

CR (Fig. 1F): 4 large, terminal setae, 1 tiny dorsal seta and 1 small medioventral setae.
Remarks. Brodskius benthopelagicus resembles Amallothrix robustipes Grice, Hulsemann, 1965, Xanthocalanus paululus Park, 1970, and Xanthocalanus paraincertus Grice, Hulsemann, 1965. The taxonomic position of these latter three species has 
remained unclear as evidenced by the assignment of these three similar species either to Amallothrix or to Xanthocalanus (Bradford, 1973; Bradford et al., 1983; Park, 1970; Roe, 1975; Ohtsuka et al., 1998). Here, all three are placed in the new genus Brodskius, resulting in a new combination for Brodskius robustipes (Grice, Hulsemann, 1965) and for Brodskius paululus (Park, 1970). The new species Brodskius confusus is established for the paratypes of $X$. paraincertus (Grice, Hulsemann, 1965) which are not conspecific with the holotype. Differences among these species are discussed following each description or redescription and in Table 1.

\section{Brodskius paululus (Park, 1970) comb. n.} Fig. 6.

Xanthocalanus paululus Park, 1970: 497, Figs. 89102; Bradford, 1973: 134, 139, 147; Roe 1975:364-366, Fig. 32 a-n (female, ?male); Bradford, Haakonssen, Jillet, 1983: 71, 123, 127; Ohtsuka, Takeuchi, Tanimura, 1998:795-796, 801.

Specimens. Adult female holotype (USNM \#123786); existing slide with $2 \mathrm{Mxps}$ and $1 \mathrm{Mx} 2$ in poor condition; both $\mathrm{A} 2, \mathrm{Mn}, \mathrm{Mx} 1, \mathrm{Mxp}$ (in poor condition) and remaining $\mathrm{Mx} 2$ dissected from holotype in ethanol.

A2: coxa and basis without setae.

Mn (Fig. 6A): gnathobase elongate, narrow medially with knob on distal face; cutting edge narrow with 2 deep incisions among teeth.

Mx1 (Fig. 6C): 1 long, thick seta with thick setules on proximal basal endite; distal basal endite fused to unsegmented $\mathrm{Ri}$; 10 setae in all (or 11 according to Park (1970: fig. 95)) on distal basal endite $+\mathrm{Ri}, 2$ broken and significantly thicker than remaining setae.

Mx2: distal endite of basis + ramus with 5 worm-like setae with setules and 3 thin brush-like setae (Fig. 6B).

Mxp: with 0, 2 and 3 setae on praecoxal endites of syncoxa (Park, 1970, fig. 97).

Remarks. States of the mandible and maxilla 1 agree with the diagnosis of Brodskius to which $X$. paululus is assigned. Brodskius paululus differs from $B$. benthopelagicus in (Table 1): cephalosome (Park, 1970, fig. 90) vaulted anteriorly (rounded anteriorly for $B$. benthopelagicus); cephalosome and Pg1 separate (fused in B. benthopelagicus); spermathecae (Park, 1970, fig. 90) smoothly rounded terminally (constricted terminally in $B$. benthopelagicus); Mx1 exopod with 2 setae (6 setae on $B$. benthopelagicus); Mx1 proximal basal endite with 3 setae (4 setae on B. benthopelagicus); P1 Von Vaupel Klein's organ (Park, 1970, fig. 98) anterior knob on endopod smoothly rounded (pointed at its tip for B. benthopelagicus).
Bradford et al. (1983:71) suggested that Xanthocalanus hispidus Grice, Hulsemann, 1967 might be identical with $B$. paululus. A slide with oral appendages of the holotype of $X$. hispidus (USNM \#113518) was examined. The following appendages differ from $B$. paululus. Mx1 proximal basal endite with 2 thin subequal setae; arthrodial membrane present between distal basal endite and $\mathrm{Ri}$; Ri without 2 long thick setae. Mx2 praecoxal endite with 3 setae; distal basal endite + ramus with 3 worm-like and 4 brush-like sensory setae. Mxp praecoxal endites of syncoxa with 1,2 (1 sensory and 1 sclerotized), 1 setae. Xanthocalanus hispidus is not identical to $B$. paululus.

Brodskius robustipes (Grice, Hulsemann, 1965) comb.n.

Fig. 7.

Amallothrix robustipes Grice, Hulsemann 1965: 239 , fig. 13f-k; Bradford, 1973: 147; Roe, 1975: 365, 367; Bradford, Haakonssen, Jillet, 1983: 123; Ohtsuka, Takeuchi, Tanimura, 1998:795.

Xanthocalanus paraincertus Grice, Hulsemann 1965 (in part, holotype): 235.

Specimens. Adult female holotype of Amallothrix robustipes (BM (NH) 1965.4.20.4): Specimen is in poor condition; the following oral appendages were studied: A2 distal armament missing; Mn Ri2 poor condition with setae missing; Mx1 only 1 limb, most setae missing; Mx2 setae of praecoxal endite missing; setae of distal endite of basis + ramus 5 setae present; Mxp both basipods and Ri missing.

Rostrum: 2 short, thin rostral filaments.

A2: coxa and basis without setae.

Mn (Fig. 7A-B): gnathobase elongate, narrow medially with a bump in distal face; cutting edge narrow with two deep incisions among teeth.

Mx1: distal basal endite fused to unsegmented $\mathrm{Ri}$; setae of endite and Ri inseparable; 2 thick setae on distal basal endite $+\mathrm{Ri}$.

$\mathrm{Mx} 2$ : distal basal endite + ramus with at least 5 worm-like setae.

P1 (Fig. 7G, H): Von Vaupel Klein's organ with recurved setae originating on basis, endopod without anterior knob but with several short denticles.

Remarks. From the above observations plus description and figures of Grice, Hulsemann (1965: 239, fig. 13f-k), including the few additional observations in Grice, Hulsemann (1967: 26), we conclude that Amallothrix robustipes should be removed to Brodskius based on 2 deep incisions on the cutting edge of Mn, a Mx1 with distal basal endite fused to unsegemented $\mathrm{Ri}$ and with 2 long thick setae, heavily setulated. While distal basal endite + ramus of Mx2 has only 5 worm-like setae, thin brush-like setae may no longer be visible on the holotype due to the poor condition. 


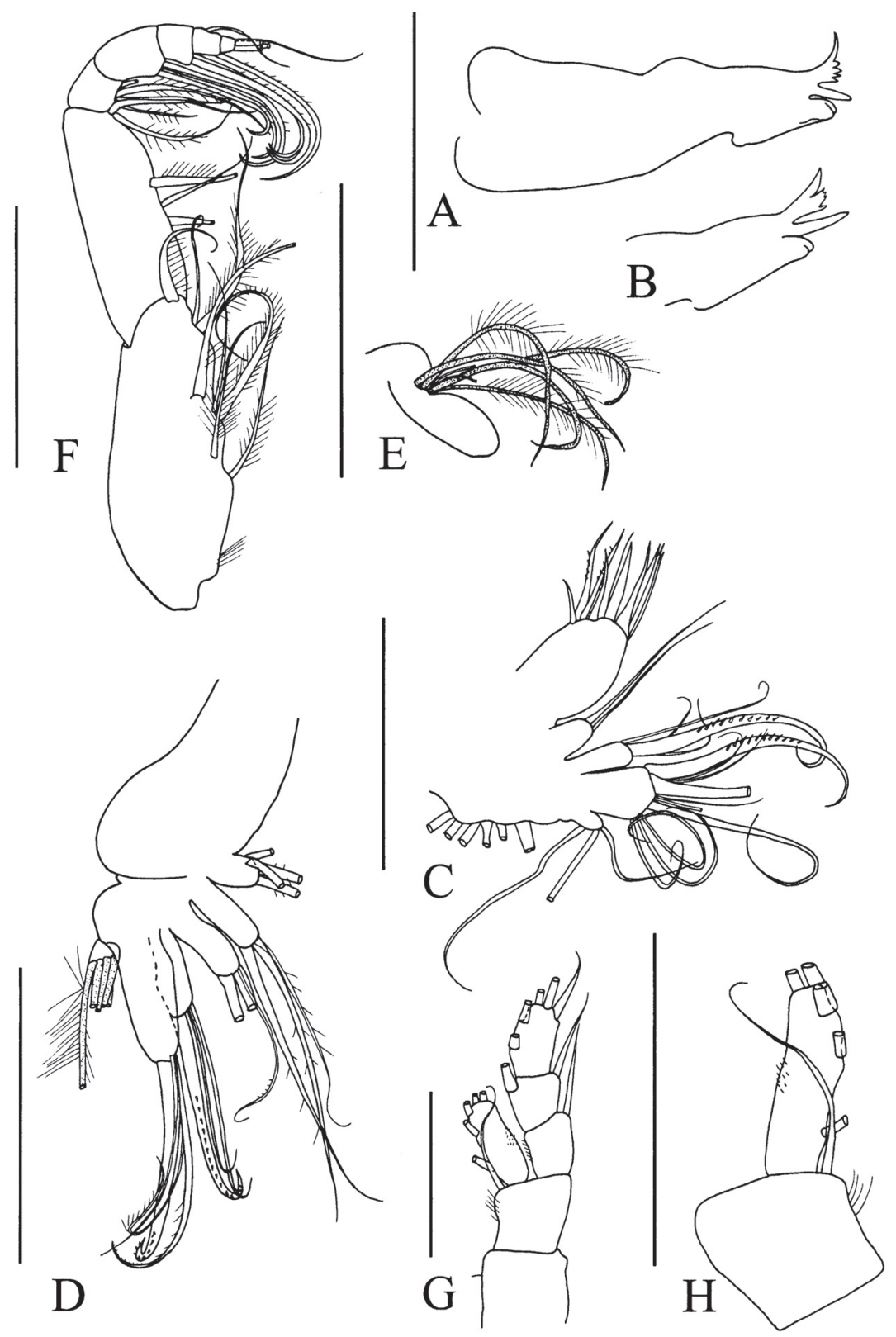

Fig. 7. Brodskius robustipes (Grice, Hulsemann, 1965) comb.n., o.:

A - mandibular gnathobase, posterior; B - mandibular gnathobase, medial section, anterior; C - maxilla 1; D maxilla 2; E - maxilla 2, sensory setae of distal endite of basis + ramus; F - maxilliped; G - swimming leg 1, anterior; $\mathrm{H}$ - swimming leg 1, basis and endopod. A-B, G-H of holotype of Amallothrix robustipes; C-F of holotype of Xanthocalanus paraincertus. Scale lines $0.1 \mathrm{~mm}$.

Pис. 7. Brodskius robustipes (Grice, Hulsemann, 1965 ) comb.n.,, :

A - гнатобаза мандибулы, задняя поверхность; В - гнатобаза мандибулы, средняя часть, передняя поверхность; C - максилла 1; D - максилла 2; E - максилла 2, сенсорные щетинки дистального базального эндита и ветви; F - максиллипеда; G - первая пара плавательных ног, передняя поверхность; $\mathrm{H}$ - первая пара плавательных ног, базис и эндоподит. А-В, G-Н, голотип Amallothrix robustipes; C-F, голотип Xanthocalanus paraincertus. Масштаб 0,1 мм. 

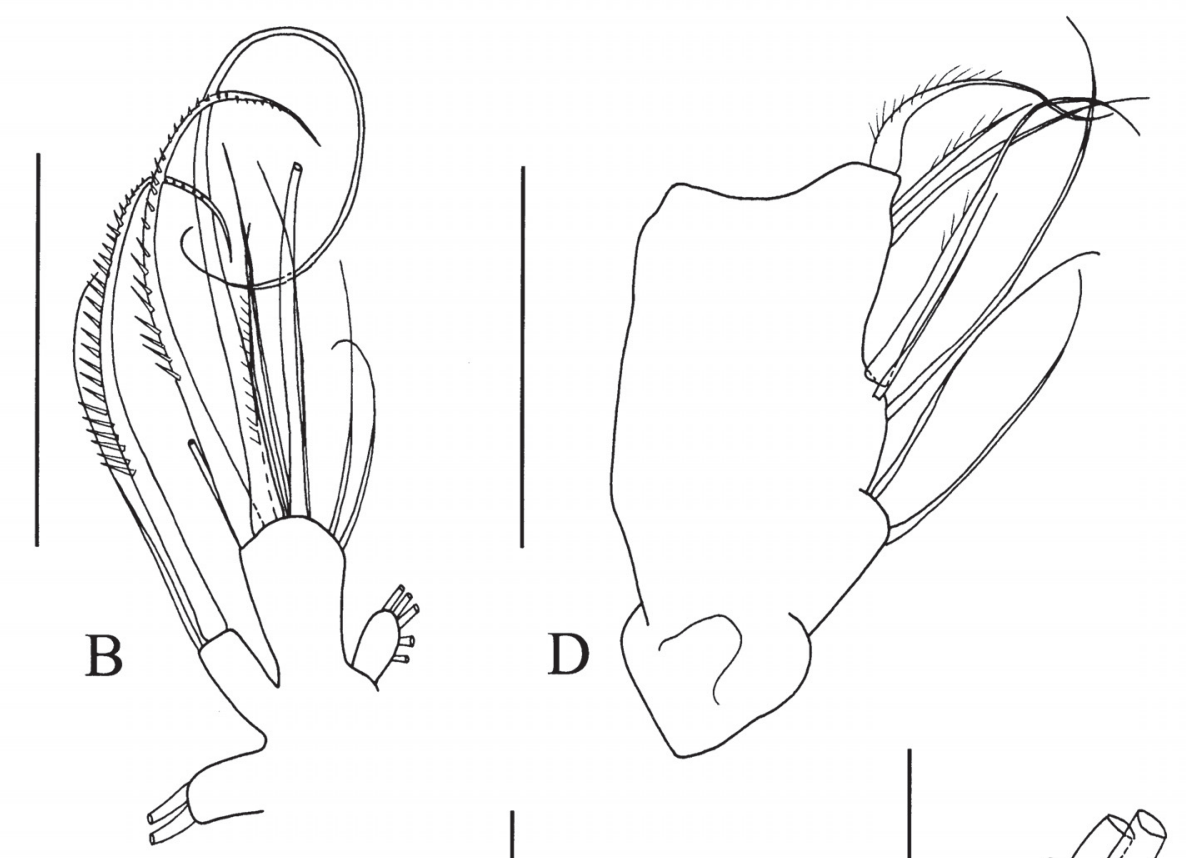

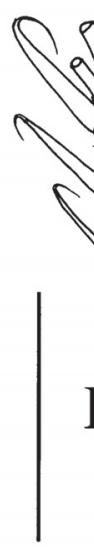
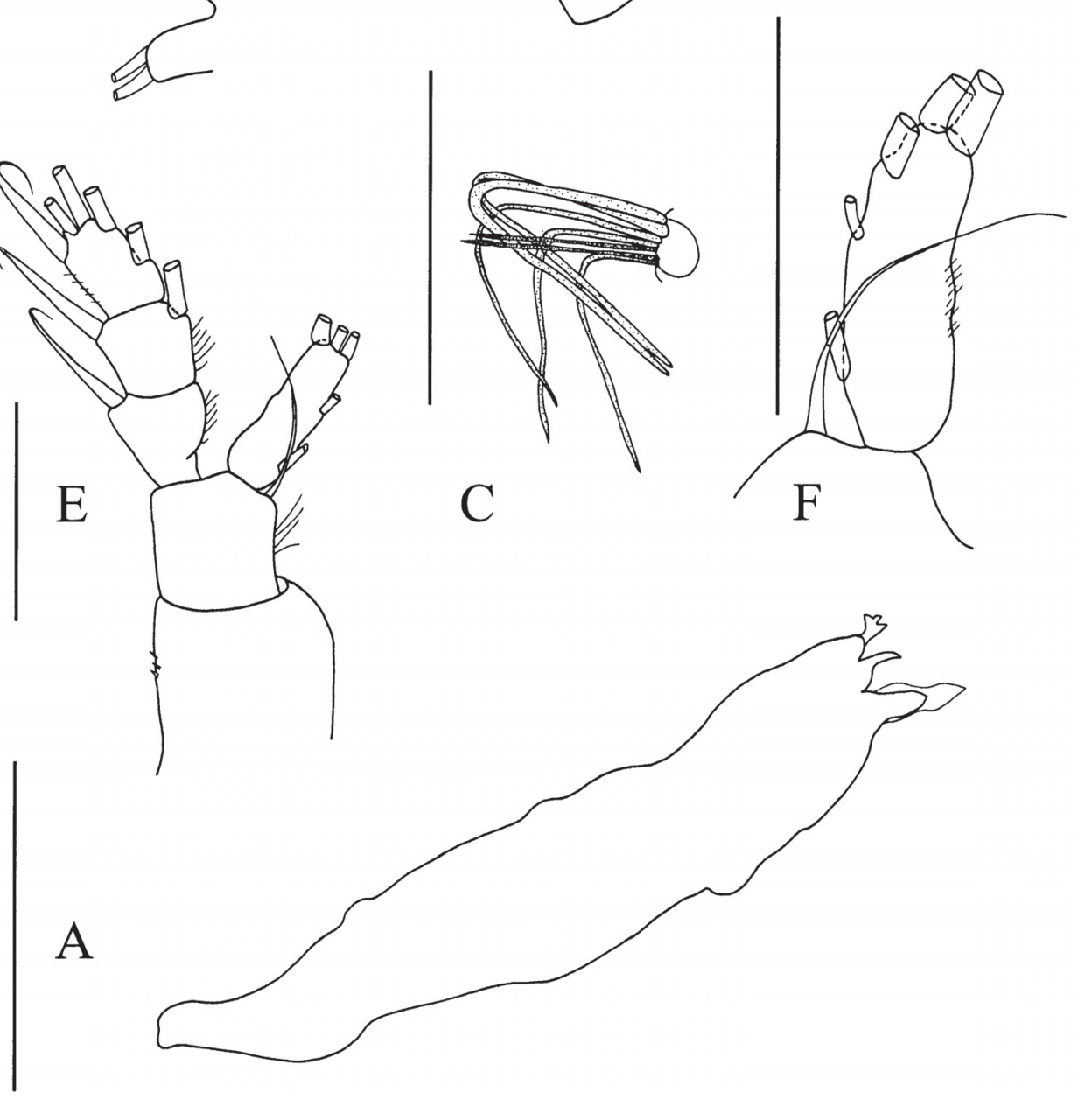
Additional specimen. Adult female holotype of Xanthocalanus paraincertus (BM(NH) 1965.4. 20.18): A2, Mn, Mx1, Mx2 and Mxp dissected and studied.

The undissected holotype of Xanthocalanus paraincertus (BM(NH) 1965.4.20.18) was dissected and the following observations made. A2: coxa and basis without setae; Ri1 with 1 seta; Ri2 with 6 terminal and 8 subterminal setae; Re 7-segmented with $0,1,1,1,1,1,3$ setae. Mn: gnathobase elongate, narrow medially with a bump in distal face; cutting edge narrow with two deep incisions among teeth; basis and proximal segment of $\mathrm{Ri}$ with 1 seta; distal segment of Ri with 9 setae; setation of $\operatorname{Re} 1,1,1,1,1$. Mx1 (Fig. 7C): praecoxal endite with 9 terminal and 1 posterior setae; coxal endite with 2 setae, epipodite with 6 setae; proximal basal endite with 4 setae, distal basal endite + Ri; setae inseparable, 10 total; Re with 3 . Mx2 (Fig. 7D, E): proximal praecoxal endite with 4 setae; distal praecoxal with 3 setae; proximal coxal endite with 3 setae, 1 thick, distal endite with 3 setae, 1 thick; proximal basal endite with 4 setae, 1 thick, claw-like; distal basal endite + ramus with 5 worm-like setae with setules and 2 small, thin brush-like setae. Mxp (Fig. 7F): praecoxal endites with $0,2,3$ setae, all sclerotized. We conclude that this previously undissected holotype of $X$. paraincertus belongs to B. robustipes.

Brodskius robustipes can be distinguished from $B$. benthopelagicus and B. paululus (Table 1) in shape of spermathecae which is oblong-rounded (subdivided into two parts of which distal part is rounded in $B$. benthopelagicus or rounded in $B$. paululus); Mx1 Re with 3 setae (6 in $B$. benthopelagicus or 2 on B. paululus); $\mathrm{Mx} 2(\mathrm{Re})$ ramus with 2 brush-like setae ( 3 on $B$. benthopelagicus and $B$. paululus); P1 Ri without anterior knob (present an acute distal in $B$. benthopelagicus or smoothly rounded on B. paululus). We then agree with Roe (1975: 367) that Amallothrix robustipes should not be placed in Amallothrix or Xanthocalanus, and do not agree that Amallothrix robustipes is synonymous with Xanthocalanus paululus; they are two different species of Brodskius.

\section{Brodskius confusus sp.n.}

Fig. 8.

Xanthocalanus paraincertus Grice, Hulsemann, 1965 (in part, paratypes): 235-237, figs. 12 a-j, 13 a-e; Park, 1970: 497; Bradford, 1973: 139, 147.

Tharybis paraincertus: Bradford, Haakonssen, Jillet, 1983: 71, 123; 127; Schulz, Beckmann, 1995: 210; Ferrari, Markhaseva, 2005: 33, 46.

Specimens. Three adult female paratypes of $X$. paraincertus (USNM \#266573, \#1073375, \#1073376) were not conspecific with the holotype. One female (USNM \#266573) had been dissected previously and catalogued about the time of the original description of $X$. paraincertus. However, no slide of dissected appendages was catalogued and that slide may still reside in the Woods Hole Oceanographic Institution. The specimen on the missing slide may have been the source for descriptions and illustrations for X. paraincertus by Grice, Hulsemann (1965: 235-237, figs. 12 a$\mathrm{j}, 13$ a-e). Subsequently, two females were located in the personal collection of George D. Grice, catalogued (USNM \#1073375, \#1073376) and dissected for the present study.

Female catalogued under USNM \#1073375 is designated as holotype.

Habitus. Body plump; spermathecae cucumber-shaped.

Rostrum: 2 long, thin filaments.

A2: coxa without seta, basis without seta; attenuate seta-like structure near the base of Ri1.

Mn (Fig. 8A): gnathobase elongate, narrow medially with a bump in distal face; cutting edge narrow with two deep incisions among teeth; Re 5segmented with $1,1,1,1,2$ setae.

Mx1 (Fig. 8B and Table 1): proximal basal endite with 2 setae, 1 long, thick and heavily setulated; distal basal endite + Ri with 9 setae total, 2 long, thick and heavily setulated; Re with 5 setae.

Mx2 (Fig. 8C): proximal praecoxal endite with 4 setae; distal with 3 setae. Proximal coxal endite with 3 setae, 1 thick, distal endite with 3 setae, 1 thick and 1 worm-like. Proximal basal endite with 4 setae, 1 thick and 1 worm-like; distal basal endite + ramus with 5 worm-like and 2 thin brush-like sensory setae.

Fig. 8. Brodskius confusus sp.n.,, :

A - mandibular gnathobase, anterior; B - maxilla 1, coxal endite, proximal and distal endites of basis, endopod and exopod; C - maxilla 2, sensory setae of distal endite of basis + ramus; D — syncoxa of maxilliped; E — right swimming leg 1, anterior; F - left endopod of swimming leg 1, anterior. Of paratype of Xanthocalanus paraincertus. Scale lines $0.1 \mathrm{~mm}$.

Рис. 8. Brodskius confusus sp.n., ․

А - гнатобаза мандибулы, передняя поверхность; В - максилла 1, коксальный эндит, проксимальный и дистальный базальные эндиты, эндоподит и экзоподит; C - максилла 2, сенсорные щетинки дистального базального эндита и ветви; D - синкокса максиллипеды; Е - правая нога первой пары плавательных ног, передняя поверхность; F — левый эндоподит первой пары плавательных ног, передняя поверхность. Паратип Xanthocalanus paraincertus. Масштаб 0,1 мм. 
Mxp (Fig. 8D): praecoxal endites of syncoxa with 0,2 and 3 sclerotized setae; Ri of 5 articulated segments with 4, 2, 2, 2+1 lateral and 4 setae.

P1 (Fig. 8E-F): Von Vaupel Klein's organ with curved basal seta and anterior knob of endopod with denticles and of low relief.

Other characters as described by Grice, Hulsemann (1965)

Remarks. Brodskius confusus shares the synapomorphies with the three other species of the genus. It is distinguished by these three states: plump body shape (elongate in other species of the genus); posterior corners of prosome slightly indented (distinctly indented in other species); long rostral filaments (short filaments in other species); Mn proximal endopodal and distal exopodal segment with 2 setae (1 seta in other species); Mx1 proximal basa endite with 2 setae ( 3 setae on B. paululus or 4 setae on $B$. benthopelagicus and B. robustipes); Ri with 9 setae (10 setae on $B$. benthopelagicus and B. robustipes or $10 / 11$ on $B$. paululus); Re with 5 setae ( 2 setae on B. paululus or 3 on B. robustipes or 6 on $B$. benthopelagicus); Mxp with 2 setae on endopodal segment adjacent to proximal segment (3 setae on other species of the genus)

\section{Brodskius sp}

Figs. 9-11.

Specimens. One male (USNM \#1080968), eastern tropical Pacific Ocean 1-5 m above Volcano 7, (dive 2147, D9, N4), 2973-2992 m.

Habitus. Total length $1.27 \mathrm{~mm}$; prosome 0.86 $\mathrm{mm}$, urosome $0.41 \mathrm{~mm}$. Cephalosome rounded anteriorly in dorsal view (Fig. 9A); cephalosome and Pg1 fused, Pg4-5 separate (Fig. 9B, C); posterior corners of prosome rounded laterally. Urosome of 5 somites; anterior somite with genital opening on left (Fig. 9B); segment adjacent to anterior somite longest; posterior somite shortest.

Rostrum (Fig. 9D): 2 filaments.

A1 (Fig. 10 A-J): right of 23 articulating segments with: $1+1,6+4,2+2,2+1,2+2,1+1,2+2$, $2+3,0+1,0+1,2+1,1+1,1+2,1+1,1+1,1+1,1+1$ $1,1,2,2,2,5+1$ setae + aesthetascs; $15^{\text {th }}$ and $16^{\text {th }}$ segment with an attenuation. Left of 24 articulating segments with: $1+1,6+4,2+2,2+1,2+2,1+1$, $2+2,2+3,0+1,0+1,2 ?, 1+1,1+2,1+1,1+1,1+1$, $1+1,1+1,1,0,1,2,2,2,5+1$ setae + aesthetascs. Eighth segment of left limb incompletely separated from $9^{\text {th }}$. Nineteenth segment of right limb apparently corresponding to the $19^{\text {th }}$ (unarmed) and $20^{\text {th }}$ segments of left limb.

A2 (Fig. 9E): coxa without seta; basis with 1 seta. Ri 2-segmented, proximal with 1 seta, distal with 6 terminal and 7 subterminal setae. Re with 0 , $1,1,1,1,1,1,3$ setae.
Mn (Fig. 9 F-G): gnathobase rudimentary; basis with 1 seta. Ri 2-segmented, proximal with seta, distal with 6 setae. Re with 1,1,1,1,2 setae.

Mx1 (Fig. 9H): without arthrodial membranes; endites of praecoxa, coxa, basis + endopod and exopod simple lobes; all setae small except for two on coxal endite.

Mx2 (Fig. 9I): proximal and distal praecoxal endites with 3 setae; proximal and distal coxal endites with 3 setae; proximal basal endite with 4 setae, 1 short worm-like; distal basal endite + ramus with 5 worm-like setae with setules and 3-brush-like setae.

Mxp (Fig. 11A): praecoxal endites of syncoxa with $0,2,3$ sclerotized setae; coxal endite with 3 setae; basis with 3 medial setae and 2 setae on distal endite; Ri with 4, 2, 2, 2+1 lateral and 4 setae.

Segmentation and setation of $\mathrm{P} 1-\mathrm{P} 4$ as for the genus except for basis of $\mathrm{P} 1$ without medial seta.

P1 (Fig. 11B): Von Vaupel Klein's organ without basal seta and anterior knob.

P2 (Fig. 11C): Ri2 with posterior spinules.

P3 (Fig. 11D): Ri2-3 with posterior spinules.

P4 (Fig. 11E): Ri3 with posterior spinules.

P5 (Fig. 11F-G): leg biramous, exceeding posterior border of urosome segment 2 (Fig. 9C); right Re 2-segmented, left Re 3-segmented; both Ri 1segmented, right small and left one longer than Re.

Remarks. We consider this specimen a male of Brodskius because: there is a sensory seta on the proximal basal endite of $\mathrm{Mx} 2$ and 5 worm-like and 3 brush-like setae on the distal basal endite + ramus; the three praecoxal endites of Mxp syncoxa have 0, 2,3 sclerotized setae. We note that there is a seta on the basis of A2 which appears to be gender dimorphic. This male may be conspecific with $B$. benthopelagicus with whose females it was collected. If so, it is larger than its conspecific female ( $1.27 \mathrm{vs}$ $1.02 \mathrm{~mm}$ ), a phenomenon unusual for calanoids. However, a similar situation was reported for $B$. paululus by Roe (1975), but that finding later was questioned by Ohtsuka et al. (1998).

\section{Byrathis gen.n.}

Diagnosis. Adult female cephalosome fused with Pg1, Pg4-5 fused dorsally, separated laterally; genital complex with small spinules dorsally and laterally. A1 of 24 articulated segments. A2, coxa and basis with 1 and 2 setae respectively; exopod with 1 , $3,1,1,1,1,1,3$. Mn gnathobase with broad medial edge and posterior tooth-like knob. Mx1 praecoxal endite with 2 posterior setae and 9 terminal setae; proximal 2 terminal setae curved proximally; coxal and proximal basal endite with 2 setae; endopod articulating with basis. Mx2 praecoxal endite with 4 sclerotized setae; proximal basal endite with 1 wormlike seta; distal basal endite + ramus with 5 worm- 


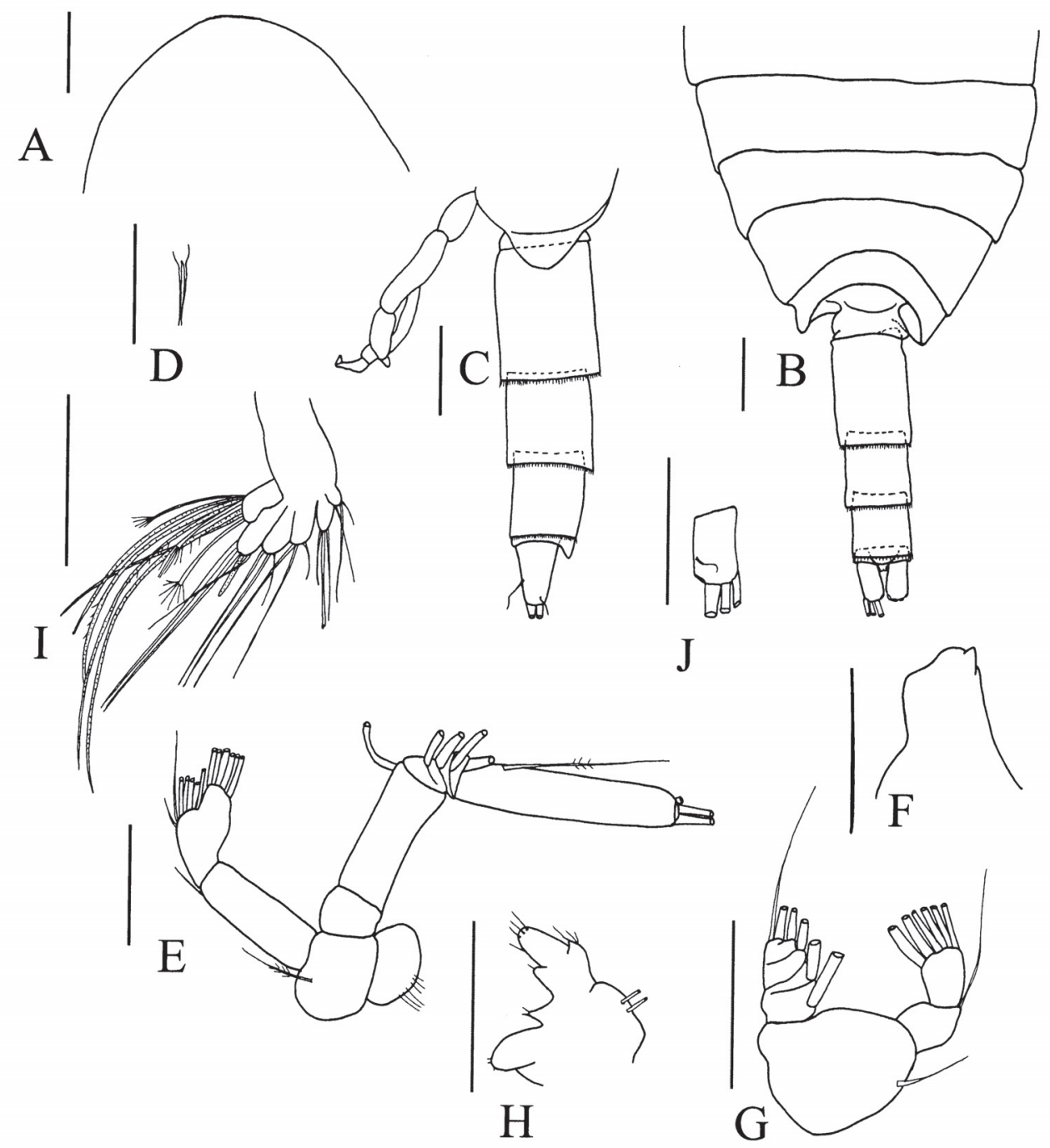

Fig. 9. Brodskius sp., O’:

A - anterior cephalosome, dorsal; B - posterior prosome and urosome, dorsal; C - posterior prosome and urosome, left lateral; $\mathrm{D}$ - rostrum; $\mathrm{E}$ - antenna 2; F - medial tip of mandibular gnathobase; $\mathrm{G}$ - mandibular palp; $\mathrm{H}$ - maxilla 1; I - maxilla 2; J - left caudal ramus, ventral. Scale lines $0.1 \mathrm{~mm}$.

Рис. 9. Brodskius sp., O’:

A — передний конец цефалосомы, вид со спины; В — задняя часть просомы и уросомы, вид со спины; С — задняя часть просомы и уросомы, слева; D - рострум; Е — антенна $2 ; \mathrm{F}$ - срединный зубец гнатобазы мандибулы; $\mathrm{G}$ - щупик мандибулы; H - максилла 1 ; I - максилла 2; J — левая CR с брюшной стороны. Масштаб 0,1 мм.

like setae and 3 short brush-like setae, one of which is thicker. Mxp praecoxal endites with 1,2 and 3 setae (distal endite with 1 worm-like seta). P1-4 of clausocalanoidean segmentation and setation. P5 $3-$ segmented, distal segment with 3 setae and terminal attenuation. Male unknown.
A synapomorphy for Byrathis is proximal 2 terminal setae on praecoxal endite of Mx1 curved proximally.

The following plesiomorphies or convergences help separate Byrathis from most other bradfordian genera: segments of the exopod of A2 with 1, 3, 1, 1, 


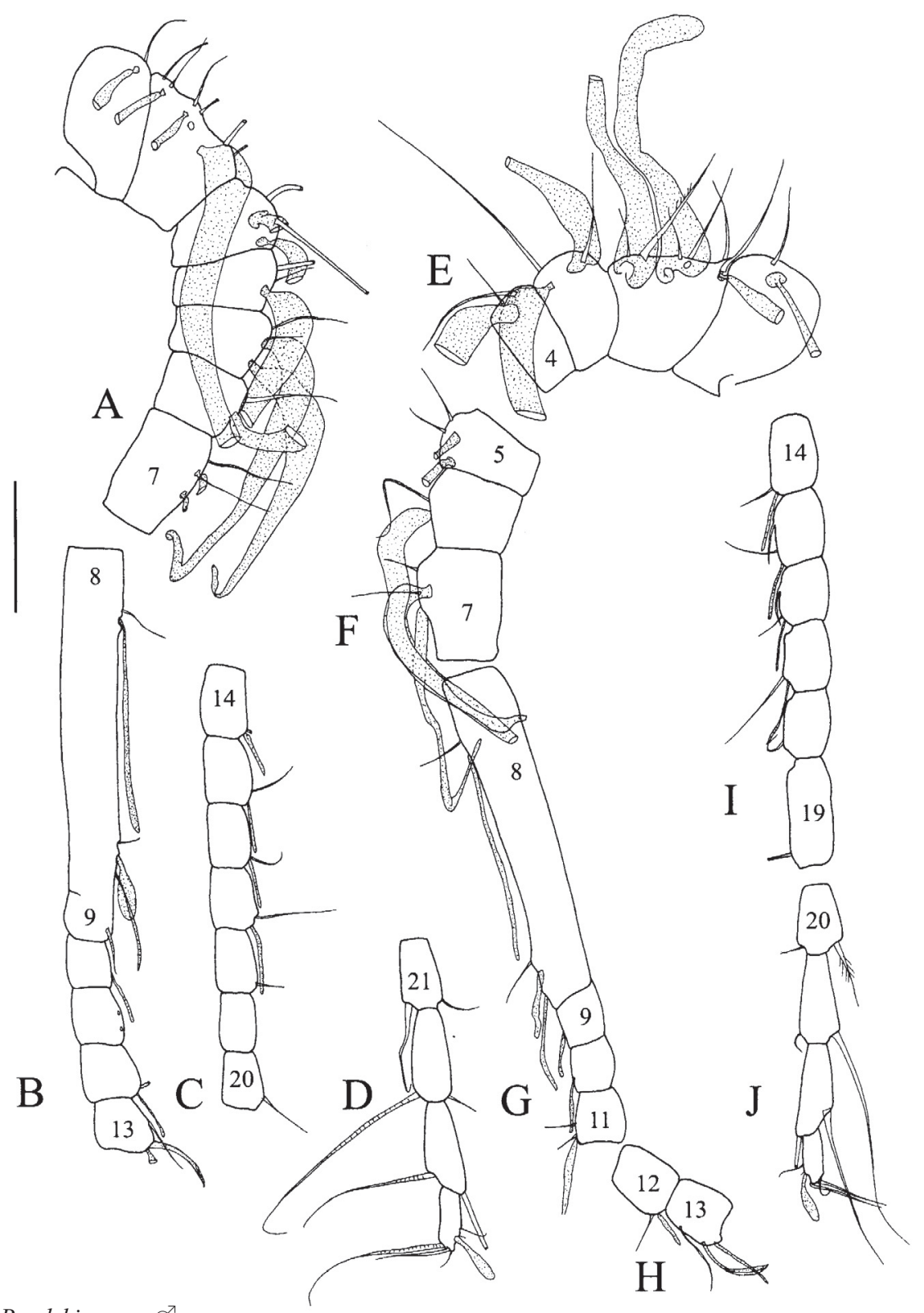

Fig. 10. Brodskius sp., O’:

A - left antenna 1, articulating segments 1-7; B — left antenna 1, articulating segments 8-13; C - left antenna 1, articulating segments 14-20; D - left antenna 1, articulating segments 21-24; E — right antenna 1, articulating segments $1-4 ; \mathrm{F}$ - right antenna 1 , articulating segments $5-7 ; \mathrm{G}$ - right antenna 1 , articulating segments $8-11 ; \mathrm{H}-$ right antenna 1 , articulating segments $12-13$; I - right antenna 1 , articulating segments $14-19$; J - right antenna 1 , articulating segments $20-23$. Scale lines $0.1 \mathrm{~mm}$.

Рис. 10. Brodskius sp., О':

А - левая антенна 1, свободные сегменты 1-7; В - левая антенна 1, свободные сегменты 8-13; С - левая антенна 1, свободные сегменты 14-20; D - левая антенна 1, свободные сегменты 21-24; E - правая антенна 1 , свободные сегменты 1-4; F - правая антенна 1 , свободные сегменты 5-7; G - правая антенна 1, свободные сегменты 8-11; Н - правая антенна 1 , свободные сегменты 12-13; I - правая антенна 1 , свободные сегменты 14-19; J - правая антенна 1, свободные сегменты 20-23. Масштаб 0,1 мм. 


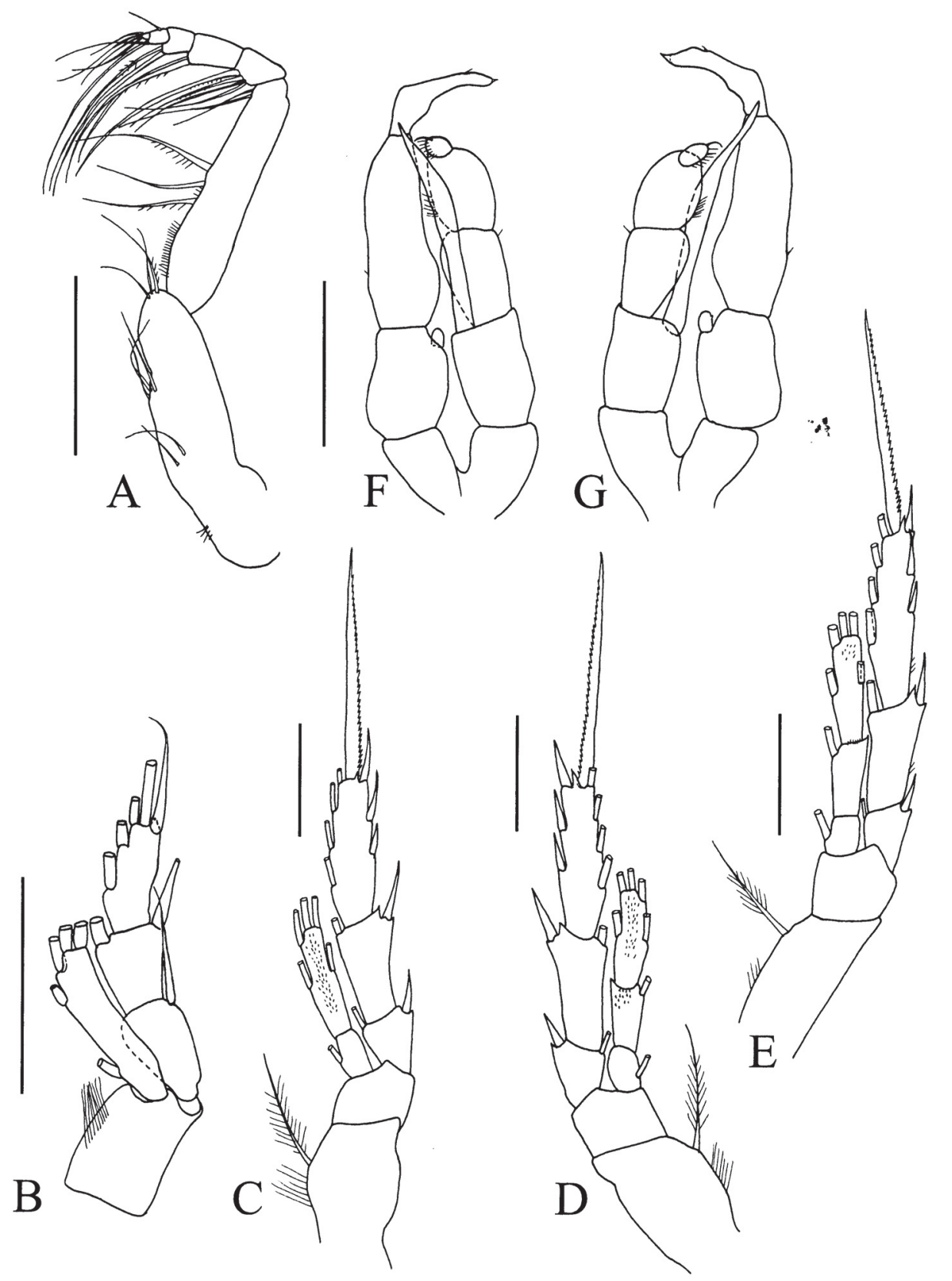

Fig. 11. Brodskius sp., $\sigma^{7}$ :

A - maxilliped; B - swimming leg 1, basis, endopod and exopod, anterior; $\mathrm{C}$ - swimming leg 2, posterior; D swimming leg 3, posterior; E — swimming leg 4, posterior; F — leg 5, posterior; $\mathrm{G}$ - leg 5, anterior. Scale lines 0.1 $\mathrm{mm}$.

Рис. 11. Brodskius sp., O’:

А — максиллипеда; В - первая пара плавательных ног, базис, эндоподит и экзоподит, передняя поверхность; C — вторая пара плавательных ног, задняя поверхность; D — третья пара плавательных ног, задняя поверхность; E — четвертая пара плавательных ног, задняя поверхность; F — пятая пара ног, задняя поверхность; $\mathrm{G}$ — пятая пара ног, передняя поверхность. Масштаб 0,1 мм. 
1, 1, 1, 3 setae (shared with Neoscolecithrix, $\mathrm{Ce}$ nognatha, some species of Diaixis, Puchinia and the following new genus Omorius); more than 4 worm-like sensory setae on basal endite + ramus of Mx2 (shared with Brodskius, Neoscolecithrix, Rythabis and the following new genus Omorius); praecoxal endites of the syncoxa of Mxp with 1,2,3 setae, (shared with Grievella, Xantharus, Falsilandrumius, Landrumius, Neoscolecithrix, Cenognatha, some species of Diaixis and some species of Tharybis); a worm-like seta on the distal praecoxal endite of Mxp (shared with some species of Diaixis). The posterior tooth-like knob on gnathobase of $\mathrm{Mn}$ (shared with the following new genus Omorius) has not been surveyed well enough to determine its usefulness for separating groups of bradfordian genera; e.g. it is present in Scolecithrix danae, Lophothrix frontalis and Scottocalanus helenae (personal observations of FDF and ELM).

Etymology. The generic name Byrathis is an anagram of Tharybis. Gender masculine.

Type species: Xanthocalanus macrocephalon Grice, Hulsemann, 1970. Other species: B. volcani sp.n., B. laurenae sp.n. and Byrathis sp.

\section{Byrathis volcani sp.n.}

Figs. 12-15

Specimens. Adult female holotype $0.77 \mathrm{~mm}$ (USNM \#1080963); prosome $0.60 \mathrm{~mm}$, urosome 0.17 $\mathrm{mm}$ from eastern tropical Pacific Ocean 1-5 m above Volcano 7, (dive 2146, D8, N8), 3022-3010.

Habitus. Total length $0.77 \mathrm{~mm}$; prosome 3.5 times longer than urosome. Cephalosome fused with $\mathrm{Pg} 1 ; \operatorname{Pg} 4$ and $\mathrm{Pg} 5$ fused dorsally, separate laterally (Fig. 12A-B, D-F). In dorsal view, cephalosome rounded anteriorly (Fig. 12A, C); posterior corners of prosome produced laterally into a short, slightly indented lobe (Fig. 12B, D, E). Genital complex symmetrical in dorsal view with a slight bump laterally, a ventral bump in lateral view, and with small spinules dorsally and laterally on this and the following somite (Fig. 12D, F-E).

Rostrum (Fig. 12C): 2 thin short filaments.

A1 (Fig. 12G): 24 articulated segments with 3, $6+1,2+1,1,1+1,2,2,2+2$ ? $, 1,1,2,1,1+1,1+$ ?, 1 , $1,1,0+1,1 ?, 1+1,1+1 ?, 2,2,4$ setae + aesthetascs.

A2 (Fig. 13A): coxa with 1 small seta; basis with 2 seta. Ri 2-segmented; proximal segment with 1 seta, distal with 15 ( 7 terminal and 8 subterminal setae). Re 8-segmented with $1,3,1,1,1$, 1, 1, 3 setae.

Mn (Fig. 14A-E): gnathobase with tooth-like knob on posterior face, cutting edge broad with 8 teeth and 1 seta; basis with 2 setae. Ri 2-segmented, proximal segment with 1 seta, distal with 9 setae. Re with $1,1,1,1$ and 2 setae.
Mx1 (Fig. 14 F-G): praecoxal endite with 2 posterior and 9 terminal setae, proximal 2 terminal setae curved proximally; coxal endite with 2 setae, epipodite with 5 setae; proximal basal endite with 2 setae; distal basal endite with 2 setae. Ri with 8 setae in groups of $2+6$. Re with 3 setae.

Mx2 (Fig. 13 B-C): proximal praecoxal endite with 4 setae; distal with 3 setae, 1 thicker. Proximal coxal endite with 3 setae, 1 thicker; distal with 3 setae, 1 thicker. Proximal basal endite with 4 setae, 1 thicker, 1 worm-like; distal basal endite + ramus with 5 worm-like and 3 brush-like sensory setae, 1 brush-like seta thicker.

Mxp (13D-E): praecoxal endites of syncoxa with 1, 2, 3 setae, 1 worm-like; coxal endite with 3 setae ( 1 broken). Basis with a row of small denticles on proximal part, 3 medial setae; 2 setae on distal endite. Ri of 5 articulated segments with $4,4,3,3+1$ lateral and 4 setae.

P1 (Fig. 15 A-C): coxa without seta; right basis with medial seta slightly curved, left without seta. Re 3 -segmented, proximal with 1 lateral seta, middle with 1 medial and 1 lateral seta, distal with 3 medial, 1 terminal, 1 lateral seta; lateral seta on proximal segment exceeds the base of lateral setae of following segment, lateral seta on middle segment does not reach the mid-length of lateral seta of terminal segment. Ri right with 2 medial and 2 terminal setae (unusual for clausocalanoideans); left with 3 medial and 2 terminal setae. Von Vaupel Klein's organ, left side, with basal seta slightly curved, anterior knob poorly developed without denticles.

P2 (Fig. 15D): coxa with medial seta; basis without seta. Re 3-segmented, proximal with 1 medial and 1 lateral seta, middle with 1 medial and 1 lateral seta, distal with 4 medial, 1 terminal and 3 lateral setae. Ri 2-segmented, proximal with 1 medial seta, distal with 2 medial, 2 terminal and 1 lateral setae; $\mathrm{Ri} 2$ with denticles on posterior surface.

P3 (Fig. 15E): coxa with medial seta; basis without seta. Re 3-segmented, proximal with 1 medial and 1 lateral seta, middle with 1 medial and 1 lateral seta, distal with 4 medial, 1 terminal and 3 lateral setae. Ri 3-segmented, proximal with 1 medial seta, middle with 1 medial seta, distal with 2 medial, 2 terminal and 1 lateral seta.

P4 (Fig. 15F): coxa with medial seta; basis without seta; denticles on posterior surface of both segments. Re 3-segmented, proximal with 1 lateral seta, middle with 1 medial and lateral seta, distal with 4 medial, 1 terminal and 3 lateral setae, denticles on posterior surface. Ri 3-segmented, proximal with 1 medial seta, middle with 1 medial seta, distal with 2 medial, 2 terminal and 1 lateral seta, denticles on posterior surface.

P5 (Fig. 15G-H): 3-segmented; proximal and middle segments (coxa and basis) with denticles; 


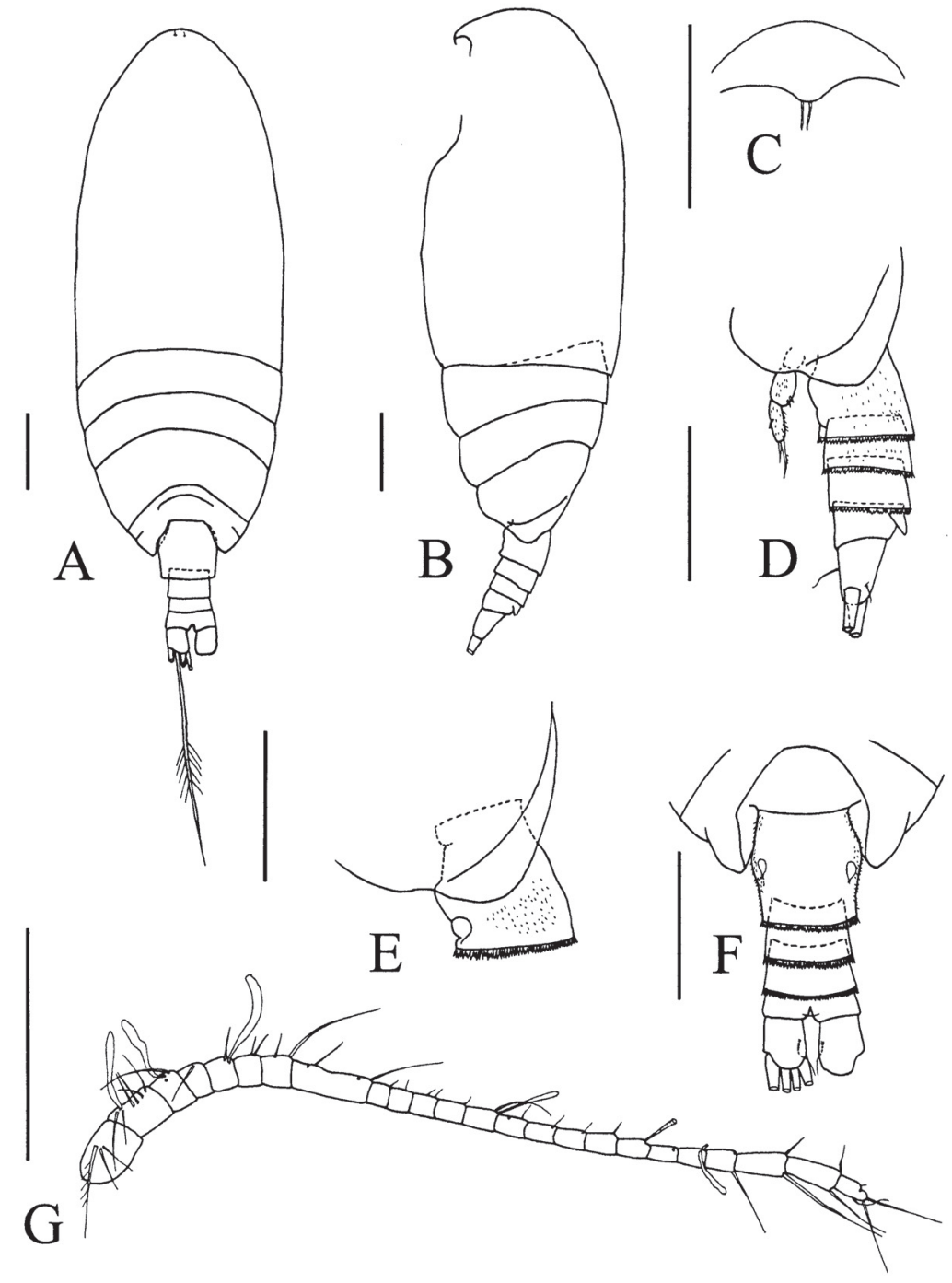

Fig. 12. Byrathis volcani gen.n., sp.n.,, :

A - habitus, dorsal; B - habitus, lateral; C - rostrum, ventral; D - posterior prosome, leg 5, and urosome, lateral; $\mathrm{E}$ - posterior prosome and genital complex, left lateral; $\mathrm{F}$ - posterior prosome and urosome, dorsal; $\mathrm{G}$ - antenna 1. Scale lines $0.1 \mathrm{~mm}$.

Рис. 12. Byrathis volcani gen. n, sp.n.,

A — общий вид, вид со спины; В — общий вид, слева; C - рострум, вид с брюшной стороны; D — задняя часть просомы, пятая пара ног и уросома слева; Е - задняя часть просомы и генитального комплекса слева; $\mathrm{F}$ - задняя часть просомы и уросома, со спины; $\mathrm{G}$ - антенна 1 . Масштаб 0,1 мм.

distal segment with 1 short lateral seta, 1 long medial attenuation and 2 subterminal setae; with denticles.

CR (Fig. 12A, D, F): 4 large, terminal setae, 1 small dorsal seta and 1 small medial ventral seta.
Differences among this species and other species of the genus are discussed following each description or redescription and are summarized in Table 2.

Etymology. The species epithet refers to Volcano 7 , the location of capture. 


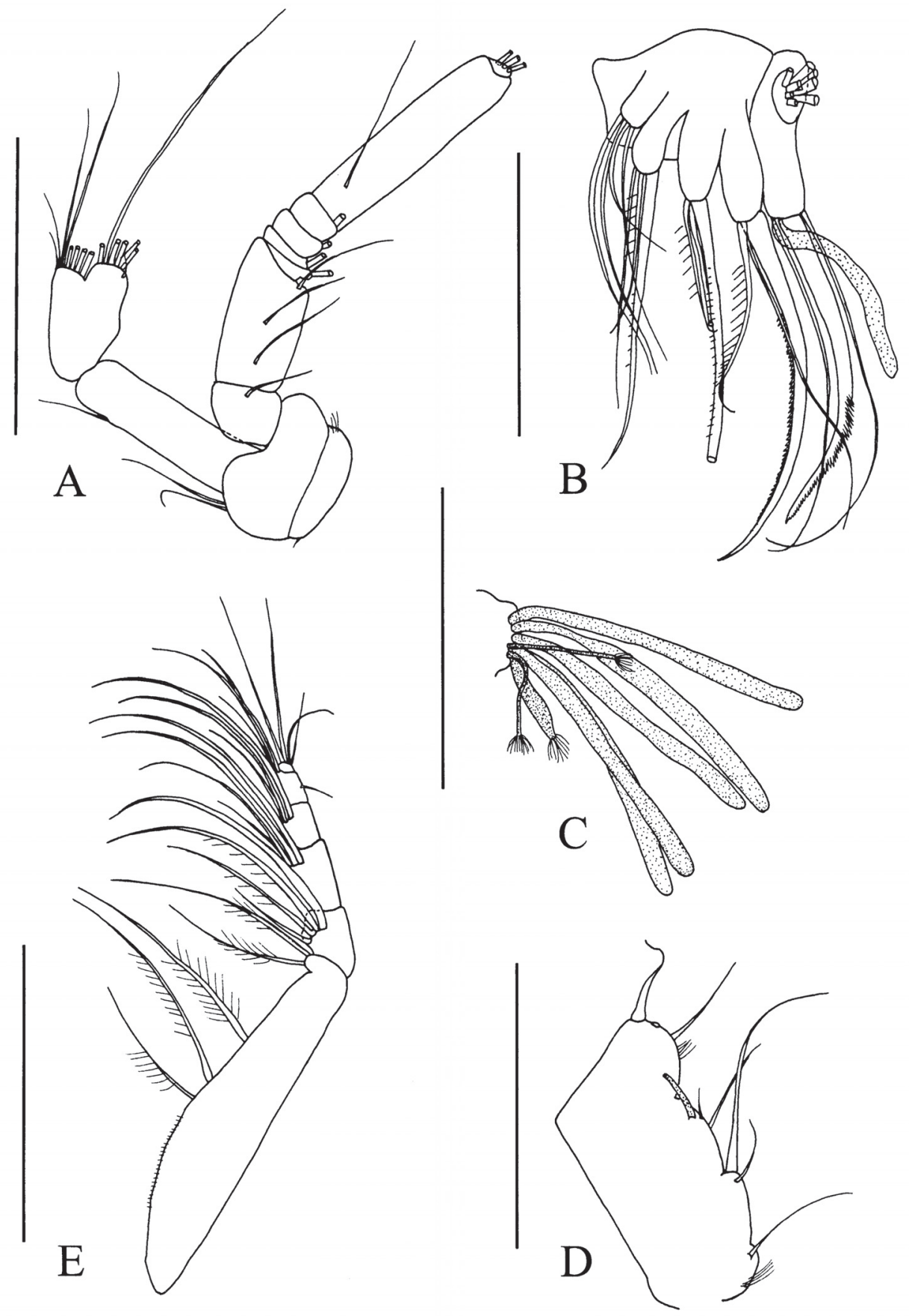

Fig. 13. Byrathis volcani gen.n., sp.n., ,

A - antenna 2; B - maxilla 2; C - sensory setae on distal endite + ramus of maxilla 2; D - syncoxa of maxilliped; E - basis and endopod of maxilliped. Scale lines $0.1 \mathrm{~mm}$.

Рис. 13. Byrathis volcani gen.n., sp.n.,, :

A - антенна 2; В - максилла 2; C - сенсорные щетинки на дистальном базальном эндите и ветви максиллы 2; D - синкокса максиллипеды; Е - базис и эндоподит максиллипеды. Масштаб 0,1 мм. 

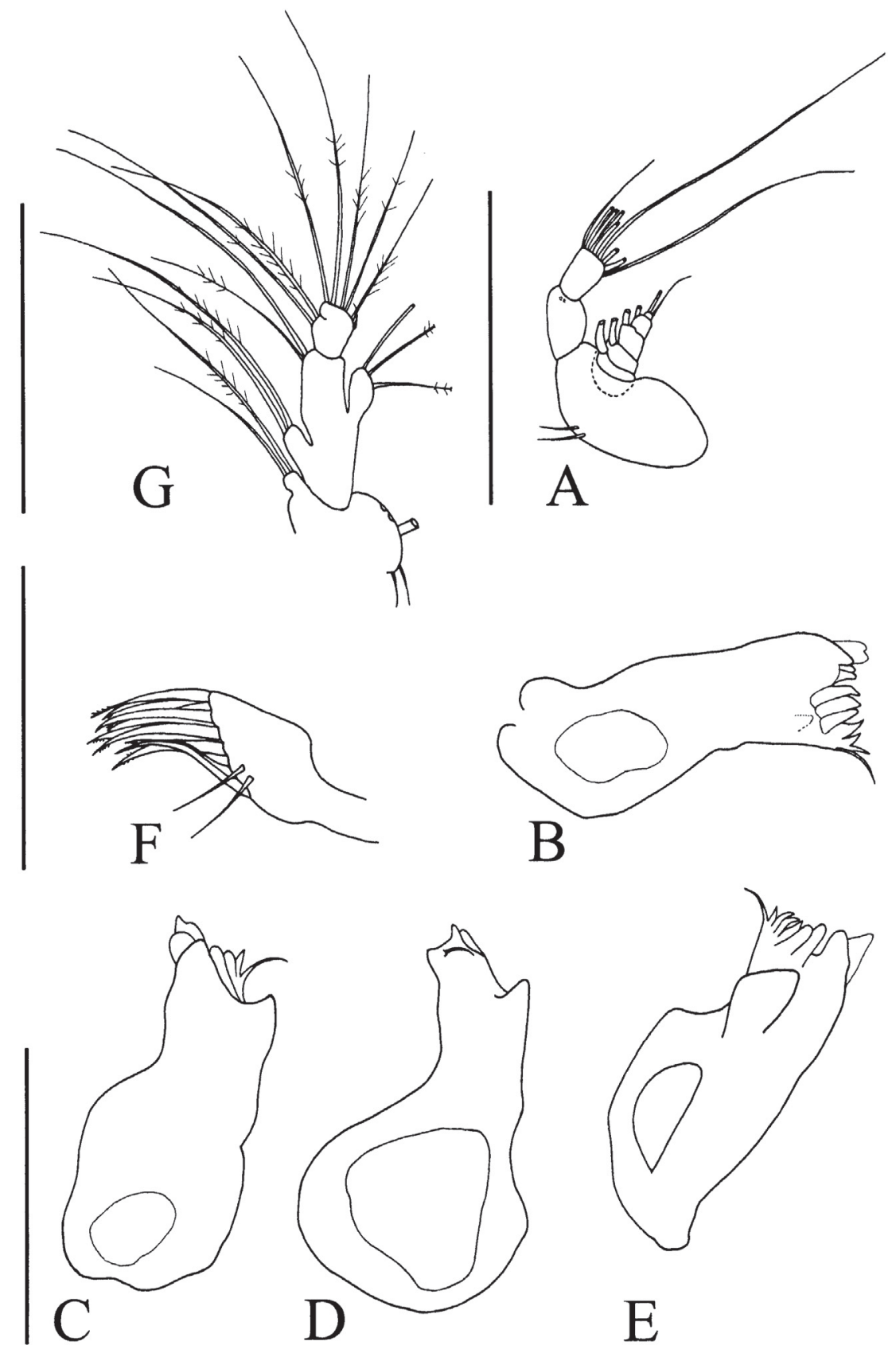

Fig. 14. Byrathis volcani gen.n., sp.n., 오

A - mandibular palp; B - vmandibular gnathobase, anterior; C - mandibular gnathobase, distal; D - mandibular gnathobase, proximal; $\mathrm{E}$ - mandibular gnathobase, posterior; $\mathrm{F}$ - praecoxal endite of maxilla $1 ; \mathrm{G}$ - coxa, basis and rami of maxilla 1 . Scale lines $0.1 \mathrm{~mm}$.

Рис. 14. Byrathis volcani gen.n., sp.n.,, :

A - щупик мандибулы; В - гнатобаза мандибулы, передняя поверхность; С - гнатобаза мандибулы, дистально; D - гнатобаза мандибулы, проксимально; Е — гнатобаза мандибулы, задняя поверхность; F прекоксальный эндит максиллы $1 ; \mathrm{G}$ - кокса, базис и ветви максиллы 1. Масштаб 0,1 


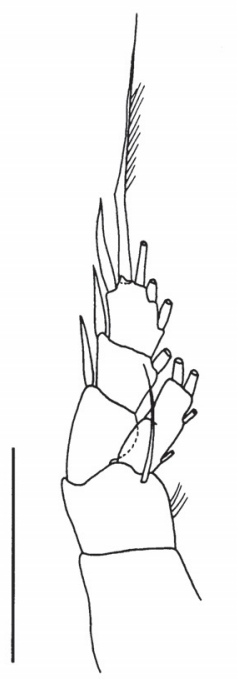

A

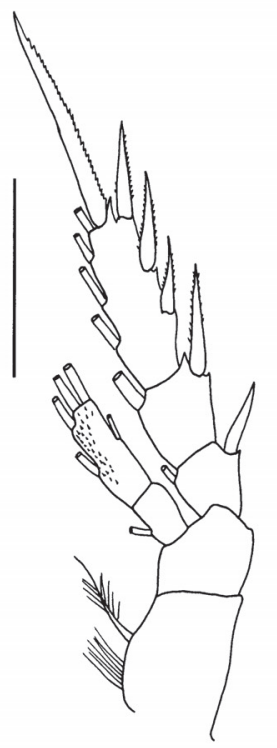

$\mathrm{D}$
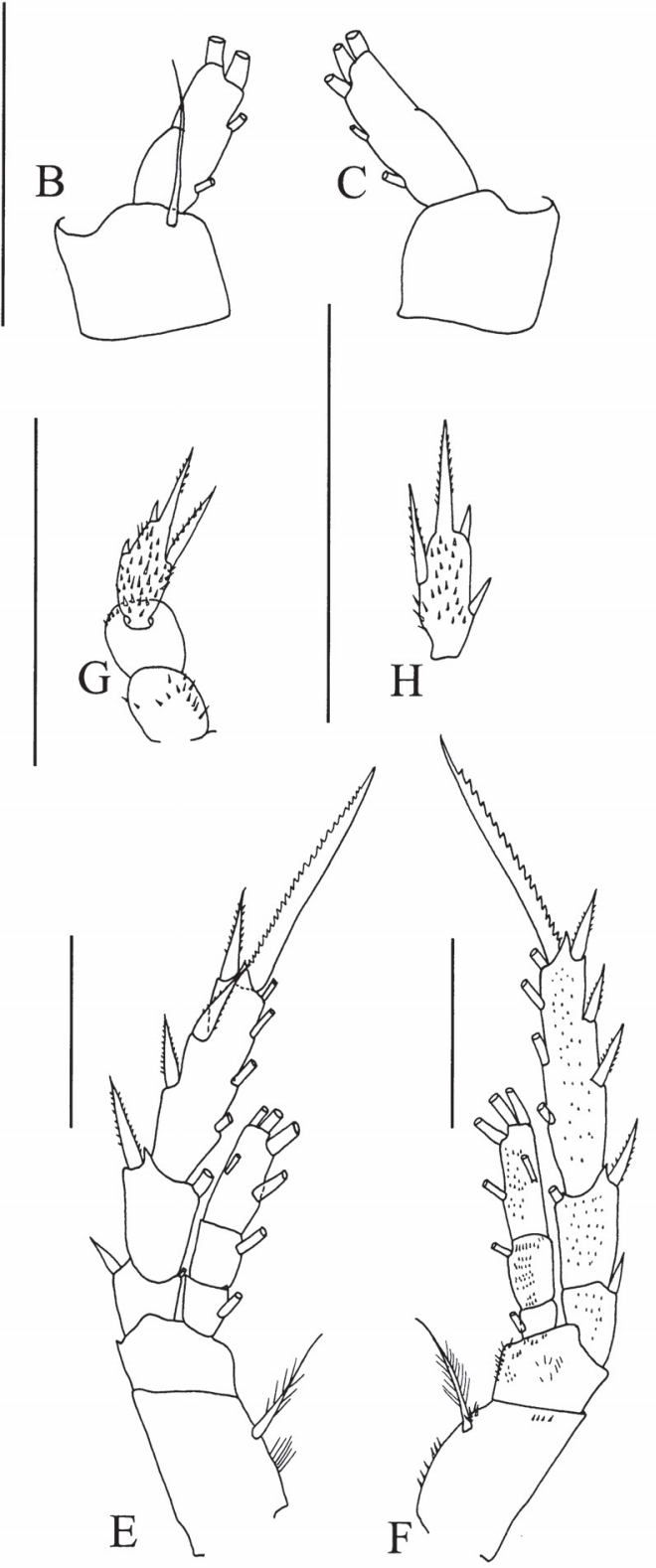

Fig. 15. Byrathis volcani gen.n., sp.n.,, :

A - swimming leg 1, anterior; B - left basis and endopod of swimming leg 1, anterior; C - right basis and endopod of swimming leg 1, anterior; D - swimming leg 2, posterior; E - swimming leg 3, posterior; $\mathrm{F}$ - swimming leg 4, posterior; $\mathrm{G}$ - right P5, posterior; $\mathrm{H}$ - left P5 exopod, posterior. Scale lines $0.1 \mathrm{~mm}$.

Рис. 15. Byrathis volcani gen.n., sp.n.,, :

A - первая пара плавательных ног, передняя поверхность; В - левый базальный членик и эндоподит первой пары плавательных ног, передняя поверхность; С - правый базальный членик и эндоподит первой пары плавательных ног, передняя поверхность; D - вторая пара плавательных ног, задняя поверхность; Е — третья пара плавательных ног, задняя поверхность; F — четвертая пара плавательных ног, задняя поверхность, $\mathrm{G}$ правая Р5, задняя поверхность; Н - левая Р5, экзоподит, задняя поверхность. Масштаб 0,1 мм. 


\begin{tabular}{|c|c|c|c|c|c|c|c|c|c|c|c|c|c|c|c|c|c|}
\hline 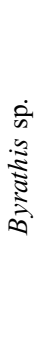 & $\begin{array}{l}m \\
\Rightarrow \\
\Rightarrow \\
\Rightarrow \\
a \\
a \\
\Rightarrow \\
\Rightarrow \\
= \\
\Rightarrow \\
\Rightarrow\end{array}$ & 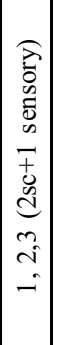 & $\stackrel{\infty}{\triangle}$ & 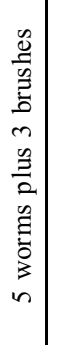 & $\stackrel{2}{=}$ & in & 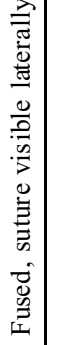 & 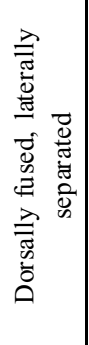 & 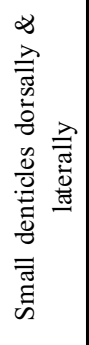 & 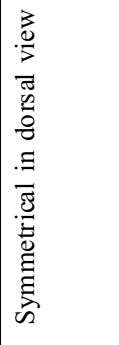 & 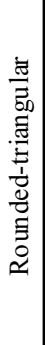 & 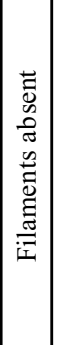 & 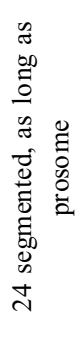 & - & $\sim$ & ફ. & ] \\
\hline 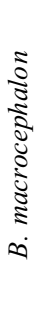 & 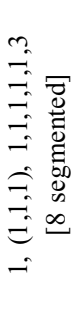 & 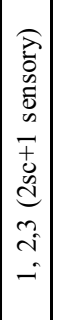 & $\stackrel{\infty}{\varnothing}$ & $\begin{array}{l}0 \\
0 \\
0 \\
0 \\
0 \\
0 \\
0 \\
0 \\
0 \\
0 \\
0 \\
0 \\
0 \\
\vdots \\
n\end{array}$ & 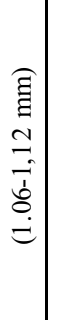 & & 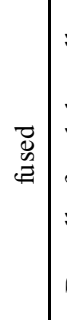 & 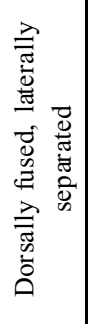 & 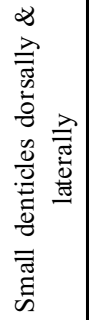 & 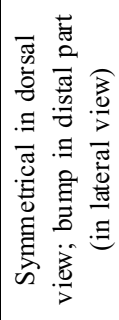 & 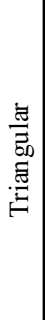 & 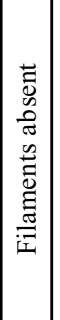 & 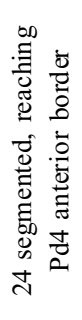 & 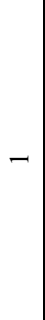 & $\sim$ & & $N$ \\
\hline 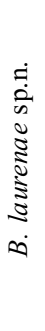 & 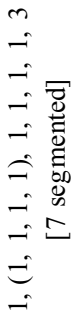 & 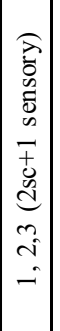 & $\stackrel{\mathscr{s}}{\stackrel{n}{2}}$ & $\begin{array}{l}0 \\
0 \\
0 \\
0 \\
0 \\
0 \\
0 \\
0 \\
0 \\
0 \\
0 \\
0 \\
0 \\
0 \\
n\end{array}$ & $\begin{array}{c}\Xi \\
\vdots \\
\vdots \\
\infty \\
0 \\
0\end{array}$ & $\mid \begin{array}{l}\infty \\
\stackrel{0}{0} \\
0 \\
0 \\
0 \\
0\end{array}$ & , & 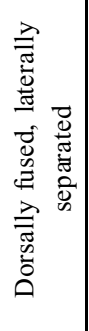 & 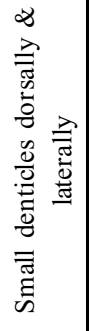 & 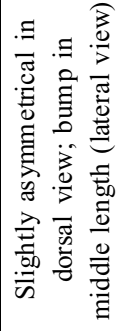 & 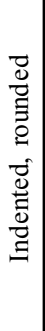 & 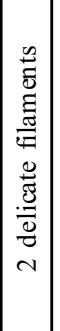 & 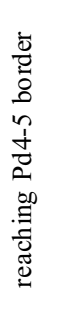 & - & $\sim$ & 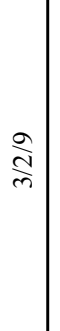 & $\sim$ \\
\hline 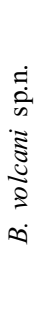 & 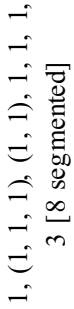 & 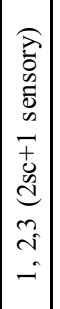 & $\stackrel{\mathscr{D}}{\check{\sim}}$ & 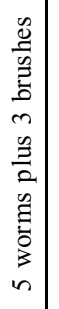 & $\begin{array}{l}\vdots \\
\vdots \\
\stackrel{0}{0} \\
\dot{0}\end{array}$ & $\begin{array}{l}7 \\
\overline{0} \\
0 \\
0 \\
0\end{array}$ & . & 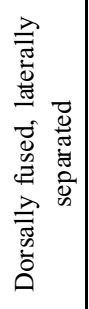 & 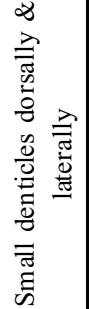 & 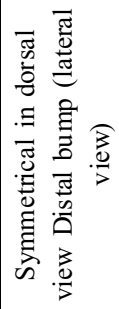 & 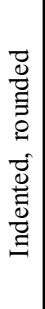 & 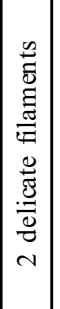 & 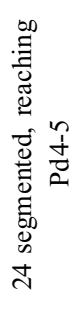 & - & $\sim$ & 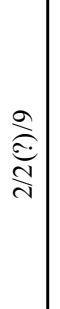 & $\sim$ \\
\hline 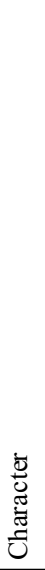 & 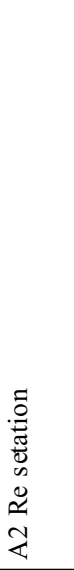 & 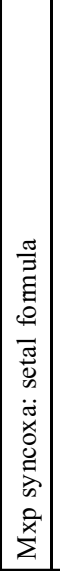 & 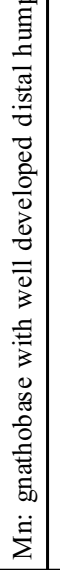 & 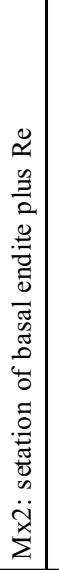 & 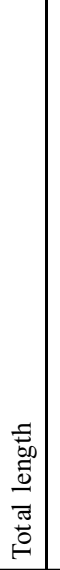 & 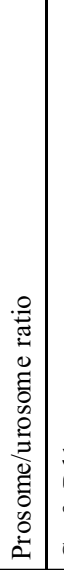 & $\begin{array}{l}z \\
z \\
0 \\
z \\
0 \\
0\end{array}$ & $\begin{array}{l}0 \\
z \\
\alpha \\
0 \\
0 \\
0\end{array}$ & 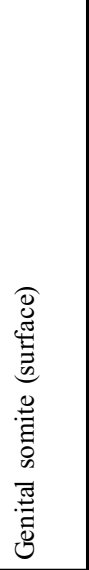 & 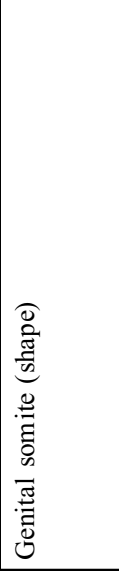 & 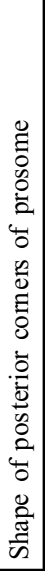 & 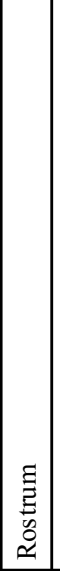 & 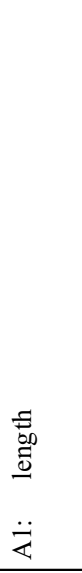 & 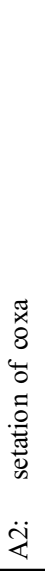 & 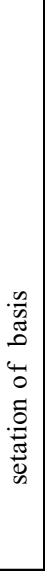 & 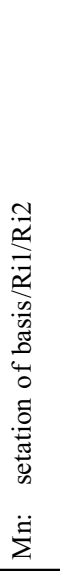 & 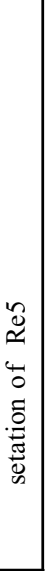 \\
\hline
\end{tabular}




\begin{tabular}{|c|c|c|c|c|c|c|c|c|c|c|c|c|}
\hline & ま & $\sim \mid$ & $\sim$ & $\tilde{i}$ & 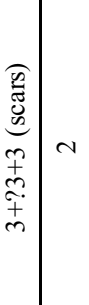 & $\checkmark \hat{r}$ & 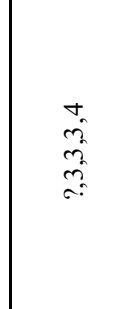 & 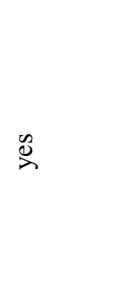 & $\begin{array}{l}+ \\
\dot{+} \\
\tilde{m} \\
\tilde{r} \\
\dot{+} \\
\dot{\theta}\end{array}$ & 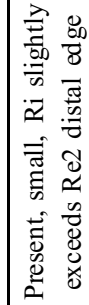 & $\begin{array}{l}\vec{z} \\
\bar{d} \\
0 \\
\overrightarrow{0}\end{array}$ & 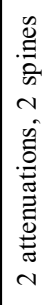 \\
\hline $\mid \begin{array}{c}5 \\
0 \\
0 \\
0 \\
0 \\
0 \\
0 \\
0 \\
0 \\
0 \\
0 \\
0\end{array}$ & $\begin{array}{l}c \\
o \\
z \\
a \\
a\end{array}$ & $\sim$ & $\sim$ & 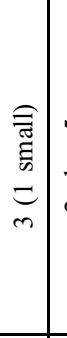 & 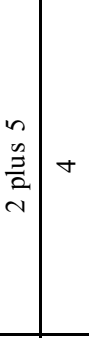 & +1 & $\begin{array}{l}\vec{r} \\
m_{2} \\
m_{2} \\
\vec{f}^{2}\end{array}$ & 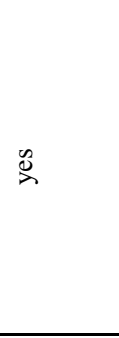 & $\begin{array}{l}\vec{\sigma} \\
\dot{+} \\
\tilde{m} \\
\dot{m} \\
\dot{\sigma} \\
\dot{\theta}\end{array}$ & 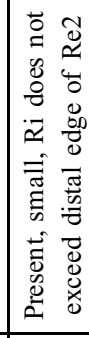 & 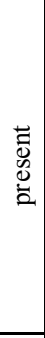 & 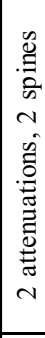 \\
\hline 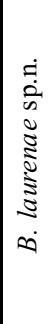 & $\begin{array}{l}n \\
o \\
z \\
\sigma \\
\sigma\end{array}$ & $\sim \mid$ & $\sim$ & $\sim$ & \begin{tabular}{l|l}
$\infty$ & +
\end{tabular} & $+\infty$ & $\begin{array}{l}\vec{r} \\
\text { mे } \\
m^{2} \\
\vec{r}\end{array}$ & $\stackrel{\mathscr{D}}{2}$ & 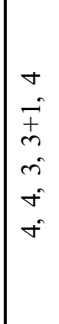 & 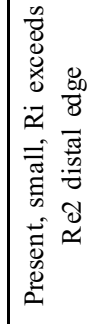 & 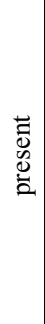 & 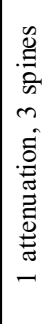 \\
\hline 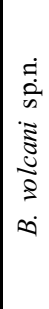 & $\begin{array}{l}N \\
o \\
z \\
\partial \\
a\end{array}$ & $\sim \mid$ & $\sim$ & $\sim$. & 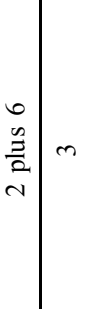 & n & $\begin{array}{l}\vec{r} \\
\vec{m} \\
m_{2} \\
\vec{f}\end{array}$ & $\stackrel{\mathscr{s}}{\grave{n}}$ & $\begin{array}{l}\vec{\sigma} \\
\vec{f} \\
\tilde{m} \\
\vec{r} \\
\dot{\sigma} \\
\dot{\sigma}\end{array}$ & 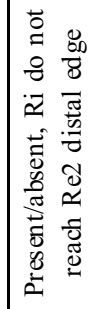 & 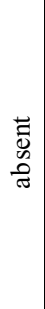 & 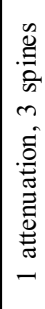 \\
\hline 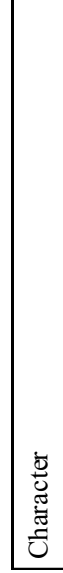 & 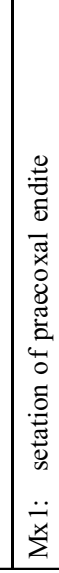 & 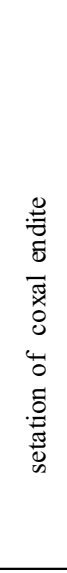 & 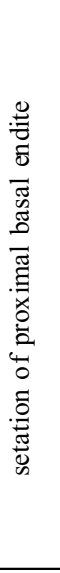 & 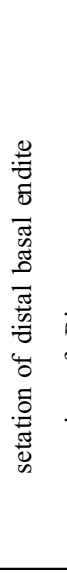 & 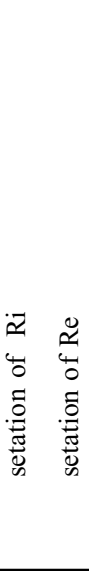 & 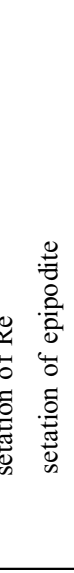 & 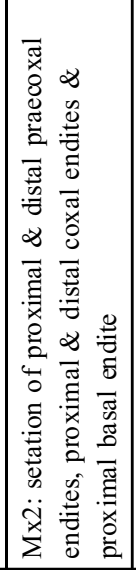 & 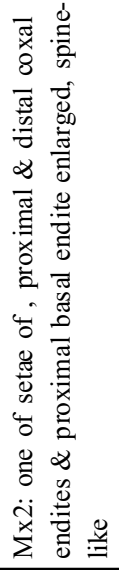 & 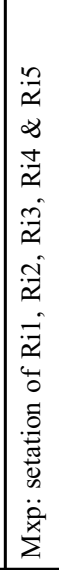 & 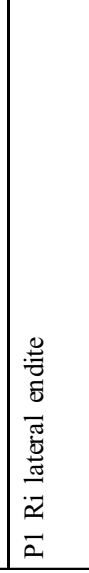 & 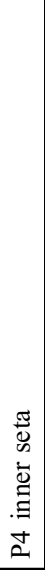 & 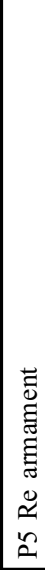 \\
\hline
\end{tabular}




\section{Byrathis laurenae sp.n.}

Figs. 16-17.

Specimens. Adult female holotype $0.87 \mathrm{~mm}$ (USNM \#1080964); prosome $0.69 \mathrm{~mm}$, urosome 0.18 $\mathrm{mm}$, from eastern tropical Pacific Ocean, ALVIN dive 3561, Biovent, 14 May 2000, depth 2,500 m, 1 m above the bottom.

Habitus. Length $0.87 \mathrm{~mm}$; prosome 3.8 times longer than urosome. Cephalosome fused to Pg1; Pg4 and Pg5 fused dorsally, separate laterally (Fig. 16A, B). Anterior cephalosome rounded dorsally (Fig. 16C, D). Posterior corners of prosome produced into short, rounded lobes in lateral view (Fig. 16A). Genital complex slightly asymmetrical in dorsal view, in lateral view with bump at midlength; with small spinules dorsally and laterally (Fig. 16A, E).

Rostrum: 2 thin short filaments.

A1: of 24 articulated segments; setation undetermined due to poor condition of antennule.

A2 (Fig. 16F): coxa with 1 seta; basis with 2 seta. Ri 2-segmented; proximal segment with 1 setae, distal with 15 setae ( 7 terminal and 8 subterminal). Re 7-segmented with 1, 4, 1, 1, 1, 1, 3 setae.

Mn (Fig. 17A): gnathobase with tooth-like knob on posterior face, cutting edge wide with 9 teeth and 1 seta. Basis with 3 setae; Ri 2-segmented; proximal segment with 2 setae, distal with 9 setae. Re with 1 , $1,1,1$ and 2 setae.

Mx1: praecoxal endite with 2 posterior and 9 terminal setae, proximal 2 terminal setae curved proximally. Coxal endite with 2 setae, coxal epipodite with 8 setae; proximal and distal basal endites with 2 setae. Ri with 8 setae in groups of $2+6$. Re with 4 setae.

Mx2 (Fig. 17 B): proximal praecoxal endite with 4 setae; distal with 3 setae, 1 thicker. Proximal coxal endite with 3 setae, 1 thicker; distal with 3 setae, 1 thicker. Proximal basal endite with 4 setae, 1 thicker, 1 worm-like; distal basal endite + ramus with 5 worm-like and 3 brush-like sensory setae, 1 brush-like seta thicker and with longer setules.

Mxp (17C): praecoxal endites of syncoxa with $1,2,3$ setae, 1 worm-like; coxal endite with 3 setae. Basis with a row of small denticles proximally, 3 medial setae, 2 setae on distal endite. Ri of 5 articulated segments with $4,4,3,3+1$ lateral and 4 setae.

P1 (Fig. 16G): coxa without seta; basis with medial seta. Re 3-segmented, proximal with 1 lateral seta, middle with 1 medial and 1 lateral seta, distal segment short with 3 medial, 1 terminal, 1 lateral seta; lateral seta on proximal segment extends to midlength of lateral setae of middle segment; lateral seta of middle segment not reaching midlength of lateral seta of terminal segment. Ri elongate, distal edge exceeding bor- der between middle and distal Re, with 3 medial and 2 terminal setae; Von Vaupel Klein's organ with basal seta uncurved, anterior knob poorly developed with denticles along lateral edge distal to anterior knob.

P2-P4: middle and distal segments of Re and Ri lost; P4 proximal segment of Re with medial seta.

P5 (Fig. 16 H): 3-segmented; proximal and middle segments (coxa and basis) with denticles; distal segment (Re) with 1 short, lateral, 1 terminal and 1 medial setae and 1 long terminal attenuation, with posterior denticles.

CR (Fig. 16A, E): only 2 long setae retained; all others broken.

Etymology. The species epithet recognizes Dr. Lauren Mullineaux's contribution to the exploration of the deep oceans.

Remarks. Byrathis laurenae can be distinguished (Table 2) from B. volcani by the former's slightly asymmetrical genital complex (symmetrical in B. volcani); 7-segmented exopod of antenna 2 (8segmented for $B$. volcani), elongate segment with 4 setae (3 setae for B. volcani); 3 setae on basis of mandible (2 setae on B. volcani); Von Vaupel Klein's organ with denticles distal to anterior knob (without distal denticles on $B$. volcani).

Byrathis macrocephalon (Grice, Hulsemann, 1970) comb.n.

Fig. 18.

Xanthocalanus macrocephalon Grice, Hulsemann 1970:191, figs. 111-127; Bradford, 1973:139, 147.

Tharybis macrocephalon: Bradford, Haakonssen, Jillet, 1983:123, 127; Schulz, Beckmann, 1995: 210; Ferrari, Markhaseva, 2005: 33, 46.

Specimens. Adult female holotype (USNM \#125141) and 3 female paratypes (USNM \#1073392).

Habitus. Adult female total length 1.06-1.12 $\mathrm{mm}$; prosome 4.6-5.4 times longer than urosome. Cephalosome fused with $\mathrm{Pg} 1 ; \mathrm{Pg} 4$ and $\mathrm{Pg} 5$ fused dorsally, separate laterally. Anterior cephalosome rounded dorsally; posterior corners of prosome produced into short, indented lobe in lateral view. Genital complex symmetrical, spermathecae elongate, dorsal part directed dorsally (Fig. 18A).

Rostrum: 2 short, thin filaments.

A1: 24 articulated segments.

A2 (Fig. 18B): coxa with 1 seta; basis with 2 setae. Ri 2-segmented, proximal segment with 1 seta; distal with 14 (6 terminal and 8 sub-terminal setae). Re 8-segmented with 1, 3, 1, 1, 1, 1, 1, 3 setae.

Mn (Fig. 18C, D): gnathobase with tooth-like knob on posterior face, cutting edge wide with 8 teeth and 1 seta; basis with 3 setae. Ri 2-segmented; proximal with 2 setae; distal with 9 setae. Re with 1 , 1, 1, 1, 2 setae. 

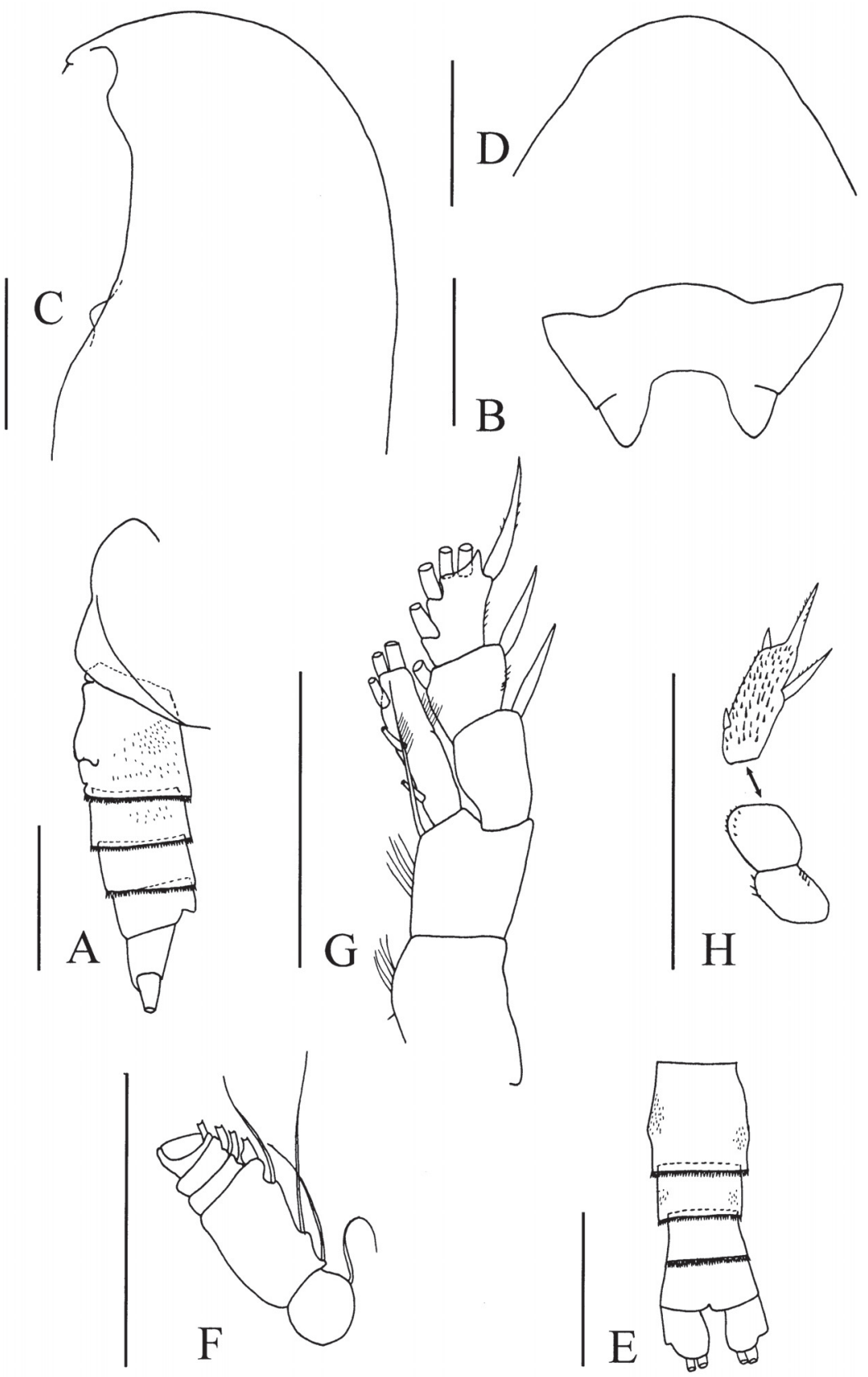

Fig. 16. Byrathis laurenae gen.n., sp.n.,, :

A - posterior prosome and urosome, left lateral; B — posterior prosome, dorsal; C — anterior cephalosome, left lateral; $\mathrm{D}$ - anterior cephalosome, dorsal; E - urosome, dorsal; F - five articulating segments of antenna 2 exopod, from basis; $\mathrm{G}$ - swimming leg 1 , anterior; $\mathrm{H}$ - right leg 5 , posterior. Scale lines $0.1 \mathrm{~mm}$.

Рис. 16. Byrathis laurenae sp.n., +

A - задняя часть просомы и уросомы слева; В - задняя часть просомы, вид со спины; С - передняя часть цефалосомы слева; D - передняя часть цефалосомы, со спины; Е - уросома, вид со спины; F — пять свободных сегментов экзоподита антенны 2, считая от базального членика; G - первая пара плавательных ног, передняя поверхность; Н - правая пятая нога, задняя поверхность. Масштаб 0,1 мм. 

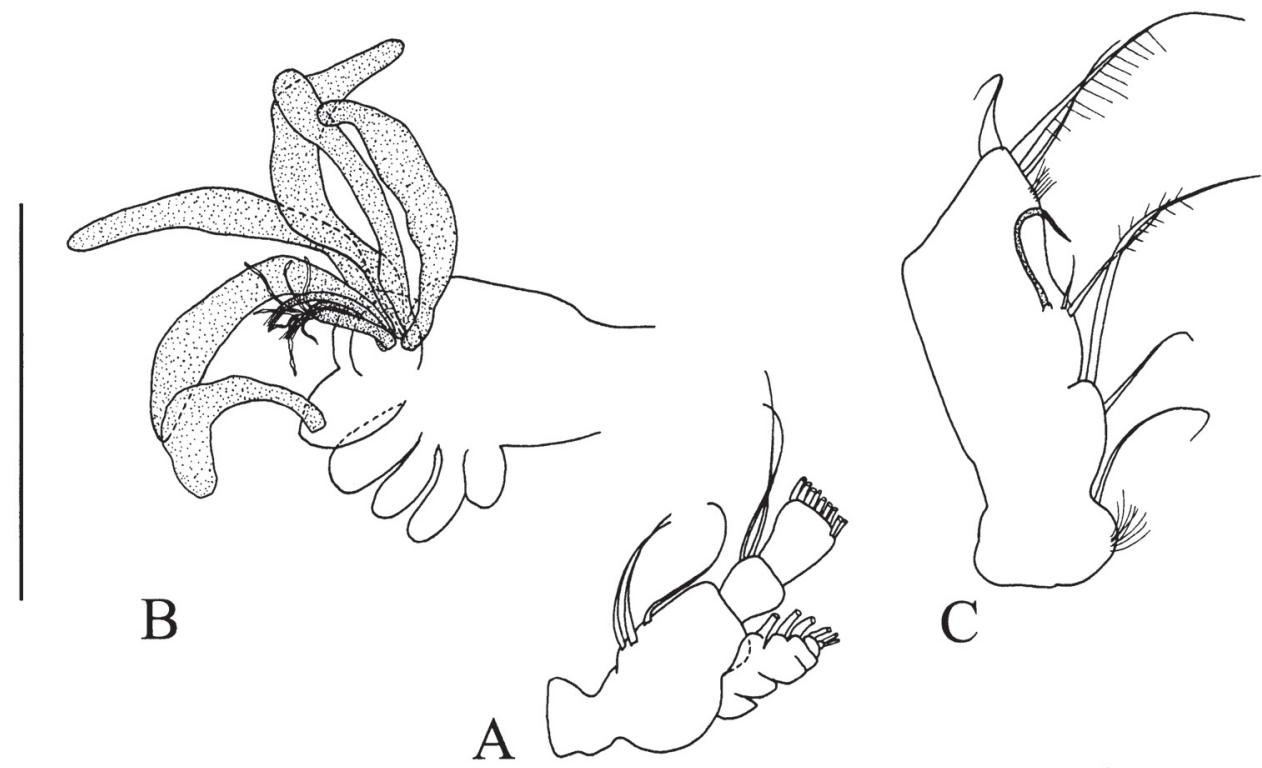

Fig. 17. Byrathis laurenae gen.n., sp.n.,, :

A - mandibular palp; B - maxilla 2, sclerotized setae of endites not drawn; $\mathrm{C}-\mathrm{v}$ syncoxa of maxilliped. Scale lines $0.1 \mathrm{~mm}$.

Рис. 17. Byrathis laurenae sp.n.,, :

A — щупик мандибулы; В - максилла 2, склеротизированные щетинки эндитов не изображены; С — синкокса максиллипеды. Масштаб 0,1 мм.

Mx1: praecoxal endite with 2 posterior and 9 terminal setae, proximal 2 terminal setae curved proximally; coxal endite with 2 setae, coxal epipodite with 7 setae; proximal basal endite with 2 setae, distal with 3 setae ( 1 of them small). Ri with 7 setae in groups of $2+5$; Re with 4 setae.

Mx2 (Fig. 18E-F): proximal praecoxal endite with 4 setae; distal with 3 setae, 1 thicker. Proximal coxal endite with 3 setae, 1 thicker; distal with 3 setae, 1 thicker. Proximal basal endite with 4 setae, 1 thicker, 1 worm-like; distal basal endite + ramus with 5 worm-like and 3 brush-like sensory setae, 1 brush-like seta thicker and with longer setules.

Mxp (Fig. 18G): praecoxal endites of syncoxa with 1, 2, 3 setae, 1 worm-like; coxal endite with 3 setae. Basis with a row of small denticles proximally, 3 medial setae, 2 setae on distal endite. Ri of 5 articulated segments with 4, 4, 3, 3+1 lateral and 4 setae.

P1 (Fig. 18H): coxa without seta; basis with medial seta. Ri with 3 medial and 2 terminal setae; Von Vaupel Klein's organ with basal seta slightly curved, anterior knob rounded and with denticles. Re 3-segmented, proximal with 1 lateral seta, mid- dle with 1 medial and 1 lateral seta, distal with 3 medial, 1 terminal, 1 lateral seta; lateral seta on proximal segment exceeds the base of lateral setae of following segment, lateral seta on middle segment exceeds half length of lateral seta of terminal segment.

P2-4 as described by Grice, Hulsemann (1970: 191-192, 210, Plate VII, Figs. 124-126).

P5: 3-segmented; Re (distal segment) with 1 long medial and 1 short lateral setae, and 1 subterminal and 1 terminal attenuation.

CR (Fig. 18A): 4 large, thick terminal setae, 1 small dorsal seta and 1 small medial ventral seta.

Remarks. Byrathis macrocephalon can be distinguished (Table 2 ) from $B$. volcani by the former's size, $1.06-1.12 \mathrm{~mm}(0.77 \mathrm{~mm}$ for $B$. volcani $) ; 3$ setae on basis of mandible (2 setae on B. volcani); distal to anterior knob of Von Vaupel Klein's organ which bears denticles (without denticles on $B$. volcani). Byrathis macrocephalon can be distinguished from $B$. laurenae by the former's symmetrical genital complex (slightly asymmetrical in B. laurenae); 8-segmented exopod of antenna 2 (7-segmented 


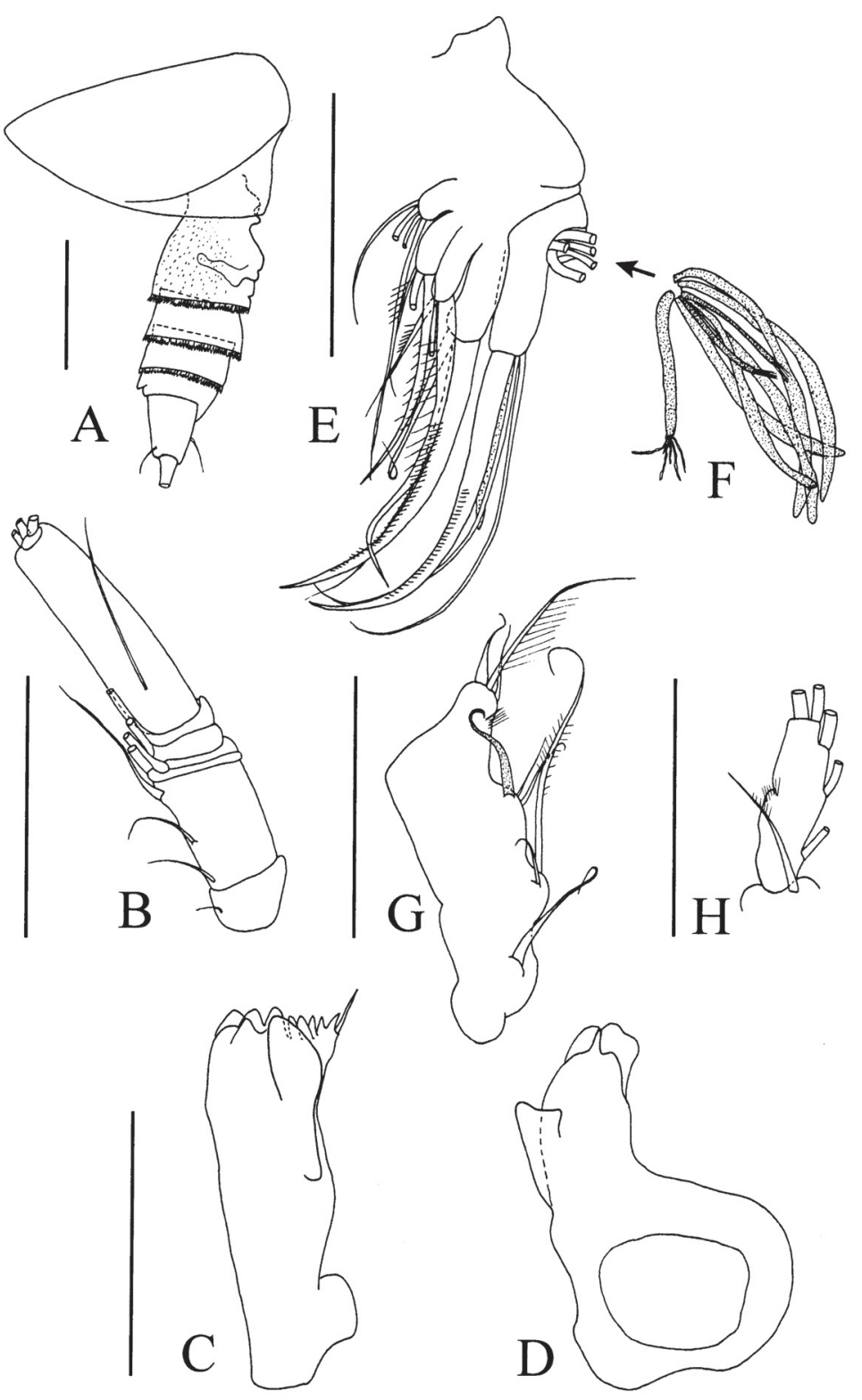

Fig. 18. Byrathis macrocephalon (Grice, Hulsemann, 1970) comb.n., $q$ (holotype):

A - posterior prosome and urosome, right lateral; B - exopod of antenna 2; C - mandibular gnathobase, posterior; $\mathrm{D}$ - mandibular gnathobase, proximal; $\mathrm{E}$ - maxilla 2, praecoxal, coxal and proximal basal endites; F - sensory setae of distal basal endite + ramus of maxilla 2; $\mathrm{G}$ - syncoxa of maxilliped; $\mathrm{H}$ - distal part of basis and endopod of swimming leg 1 , anterior. Scale lines $0.1 \mathrm{~mm}$.

Рис. 18. Byrathis macrocephalon (Grice, Hulsemann, 1970) comb.n., ф (голотип):

$\mathrm{A}$ - задняя часть просомы и уросома, справа; В - экзоподит антенны 2; C - гнатобаза мандибулы, задняя поверхность; D - гнатобаза мандибулы, проксимально; Е - максилла 2, прекоксальные, коксальные и проксимальный базальный эндиты; F - сенсорные щетинки дистального базального эндита и ветви максиллы 2; G - синкокса максиллипеды; H - дистальная часть базального членика и эндоподит первой пары плавательных ног, передняя поверхность. Масштаб 0,1 мм. 
for $B$. laurenae) and elongate segment with 3 setae (4 setae for $B$. laurenae).

Byrathis sp.

Fig. 19.

Specimens. 1 female (USNM \#1080969), 1.15 $\mathrm{mm}$; prosome $0.69 \mathrm{~mm}$, urosome $0.18 \mathrm{~mm}$ from eastern tropical Pacific Ocean, Volcano 7; submersible Alvin, dive 2147, D9, N4, depth 2973-2992 (1-5 m above the bottom).

Habitus. Adult female total length $1.15 \mathrm{~mm}$; prosome 5 times longer than urosome.

Cephalosome fused with $\mathrm{Pg} 1 ; \operatorname{Pg} 4$ and $\mathrm{Pg} 5$ fused dorsally, separate laterally. Posterior corners of prosome triangular lobes in lateral view (Fig. 19B). Genital complex symmetrical in dorsal view (Fig. 19A); small denticles dorsally and laterally on genital segment and following two abdominal segments.

Rostrum: without filaments.

A1: 24 articulated segments.

A2 (Fig. 19C): coxa with 1 seta; basis with 2 seta. Ri 2-segmented, proximal segment with 1 seta, distal with 15 ( 7 terminal and 8 sub-terminal setae). Re 8-segmented with arthrodial membrane between $3^{\text {rd }}$ and $4^{\text {th }}$ segments present ventrally and with 1,3 , $0(?), 1,1,1,1,3$ setae.

Mn: gnathobase with tooth-like knob on posterior face; palp with missing setae.

Mx1: praecoxal endite with 2 posterior and 9 terminal setae, proximal 2 terminal setae curved proximally; setae missing from coxal endite and coxal epipodite, basal endites and Ri.

Mx2 (Fig. 19D-E): proximal praecoxal endite with missing setae; distal with 3 setae, one thicker. Proximal coxal endite with 3 setae, 1 thicker; distal with 3 setae, 1 thicker. Proximal basal endite with 4 setae, 1 thicker, 1 worm-like; distal basal endite + ramus with 5 worm-like and 3 brush-like sensory setae, 1 brush-like seta thicker and with longer setules than others.

Mxp (19F): praecoxal endites of syncoxa with 1, 2, 3 setae, 1 worm-like; coxal endite with 3 setae. Basis with a row of small denticles proximally, 3 medial setae, 2 setae on distal endite. Ri of 5 articulated segments with 4, 4, 3, 3+1 lateral and 4 setae.

$\mathrm{P} 1-\mathrm{P} 4$ : segments missing from most rami; except fragments of P1-P2, with clausocalanoidean setation as described for the genus; P1 Von Vaupel Klein's organ with seta of basis slightly curved and slightly recurved, anterior knob of endopod with denticles.

P5 (Fig. 19G): 3-segmented; distal segment (Re) with 1 long medial and 1 short lateral setae, and 1 subterminal and 1 terminal attenuation.

CR: 4 large, thick terminal setae, 1 small dorsal seta and 1 small medial ventral seta; terminal setae broken.

Remarks. This specimen is not given a biological name because it has been damaged significant- ly. Terminal setae of the praecoxal endite of maxilla 1 are present, and the proximal 2 setae are curved proximally, a synapomorphy for Byrathis. The architecture of the exopod of antenna 2 is unique; the arthrodial membrane separating 2 segments distal to the long segment has formed ventrally but is absent dorsally, and the proximal to these two segments does not bear a seta.

\section{Omorius gen.n.}

Diagnosis. Adult female with cephalosome and Pg1 fused dorsally, separate laterally; Pg4-5 fused dorsally, separate laterally. Posterior corners of prosome as rounded lobes in lateral view. Rostrum without filaments. A1 of 24 articulated segments. A2 coxa with 1 seta, basis with 2 setae; Re with $1,3,1,1$, $1,1,1,3$ setae. Mn gnathobase with a tooth-like knob on posterior face; cutting edge wide proximal to distal. Mx1 praecoxal endite with 4 posterior setae and 9 terminal setae, $3^{\text {rd }}$ and $4^{\text {th }}\left(2^{\text {nd }}\right.$ and $3^{\text {rd }}$ from proximal seta) thin and slightly curved; coxal endite with 2 setae, coxal epipodite with 9 setae; proximal basal endite with 2 setae; distal basal endite with 3 setae; Ri articulating with basis with groups of 2 and 5 setae; Re with 4 setae. Mx 2 praecoxal endite with 4 setae; proximal and distal coxal endites with 3 setae, 1 thicker; and proximal basal endite with 4 setae, 1 thicker, 1 worm-like; distal basal endite + ramus with 5 long, worm-like setae and 3 short, brush-like setae. Mxp praecoxal endites of syncoxa with 1,2, 1 sclerotized setae; coxal endite with 3 setae; Ri of 5 articulated segments with $4,4,3,3+1$ and 4 setae. P1-4 clausocalanoidean segmentation and setation. P5 3segmented, distal segment with 3 setae and terminal attenuation.

Remarks. At present $3^{\text {rd }}$ and $4^{\text {th }}$ thin and slightly curved setae on the praecoxal endite of Mx1 is the only proposed synapomorphy for the monotypic Omorius. A sclerotized seta on distal praecoxal endite of Mxp syncoxa is shared with Archescolecithrix although the latter genus has 5 brush-like and 3 worm-like setae on the distal basal endite + ramus of $\mathrm{Mx} 2$, a situation reversed for Omorius. On the remaining 17 scolecitrichid-like genera, a brushlike seta replaces the sclerotized seta on the distal praecoxal endite of Mxp syncoxa. On the remaining bradfordian genera, two or three setae are found on this endite.

The following states appear to be convergent in Omorius and other bradfordian genera: 2 setae on proximal basal endite of Mxl (shared with Scolecitrichopsis, Byrathis, some species of Brodskius, and of Diaixis); 3 setae of distal basal endite of Mx1 (shared with Phaenna, some species of Byrathis, of Tharybis, and of Diaixis); 4 setae on the exopod of Mx1 (shared with some species of Byrathis, of Brodskius, of Rythabis and of Tharybis). A tooth-like knob 

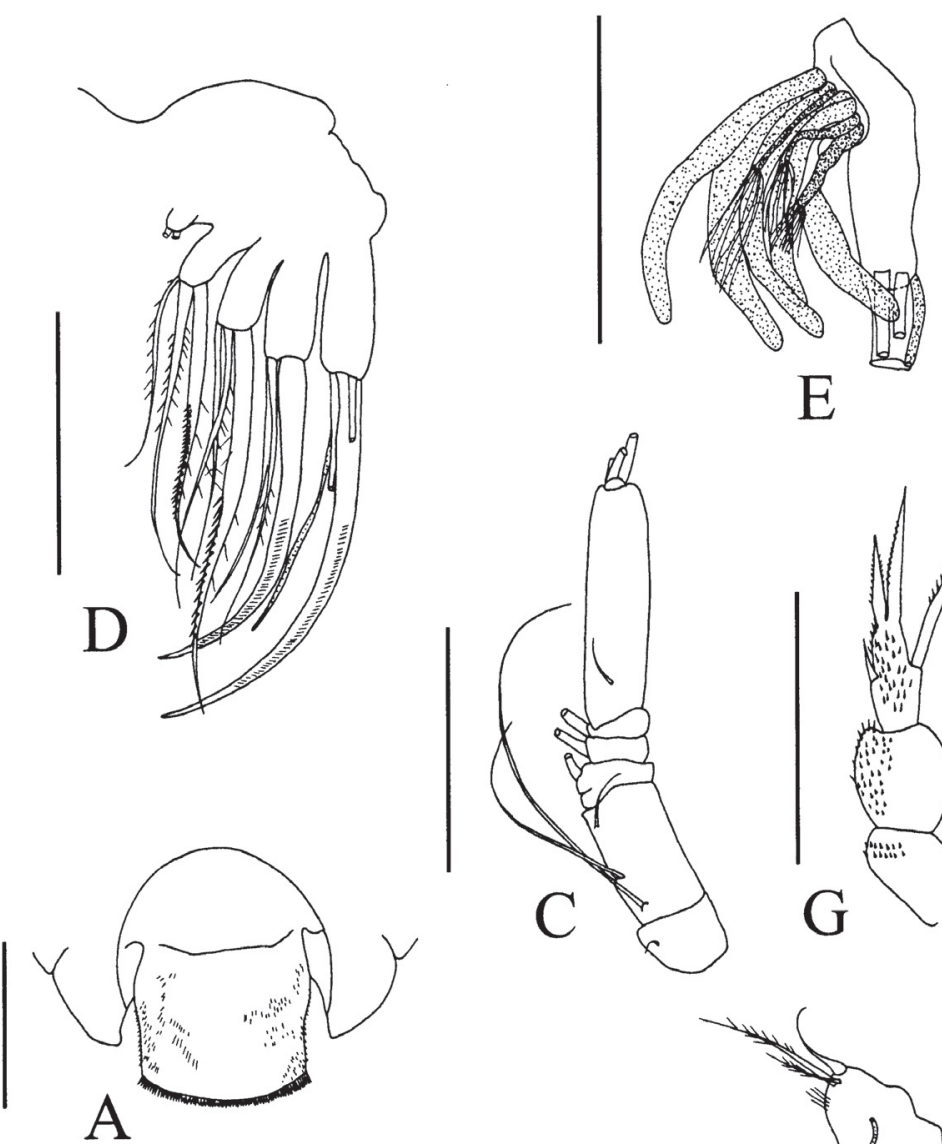

$\mathrm{E}$
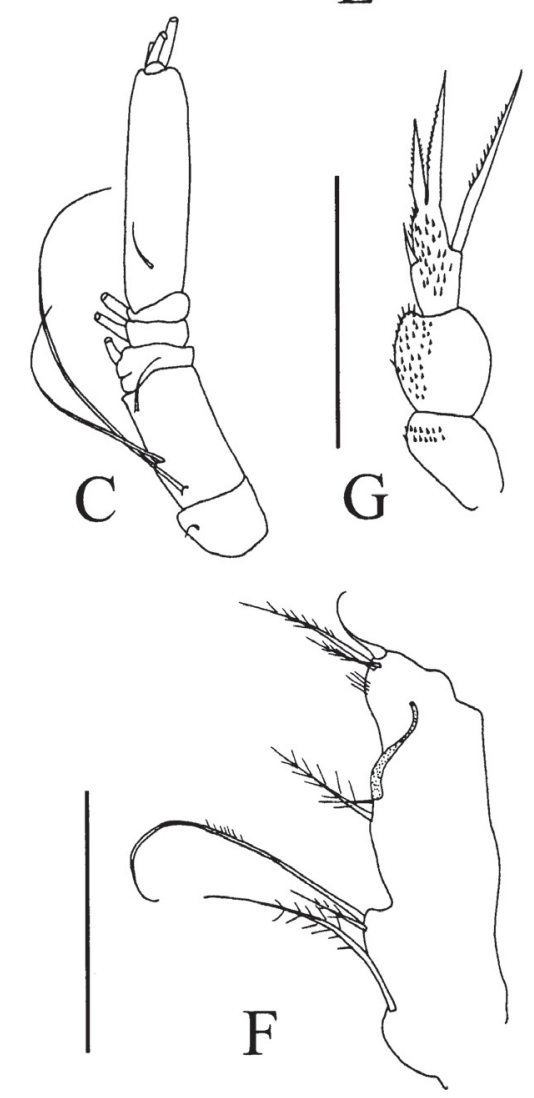

Fig. 19. Byrathis sp.,, :

A - posterior prosome and genital complex, dorsal; B - posterior prosome and genital complex, lateral; C - exopod of antenna 2; D - praecoxal, coxal and proximal basal endites of maxilla 2; E - maxilla 2, sensory setae of proximal basal endite and distal basal endite + ramus; F - syncoxa of maxilliped; $\mathrm{G}$ - leg 5. Scale lines $0.1 \mathrm{~mm}$.

Рис. 19. Byrathis sp., + :

A - задняя часть просомы и генитальный комплекс, вид со спины; В - задняя часть просомы и генитальный комплекс, справа; C - экзоподит антенны 2; D - прекоксальные, коксальные и проксимальный базальный эндиты максиллы 2; E - максилла 2, сенсорные щетинки проксимального базального эндита, дистального базального эндита и ветви; $\mathrm{F}$ - синкокса максиллипеды; $\mathrm{G}$ - пятая пара ног. Масштаб 0,1 мм. 


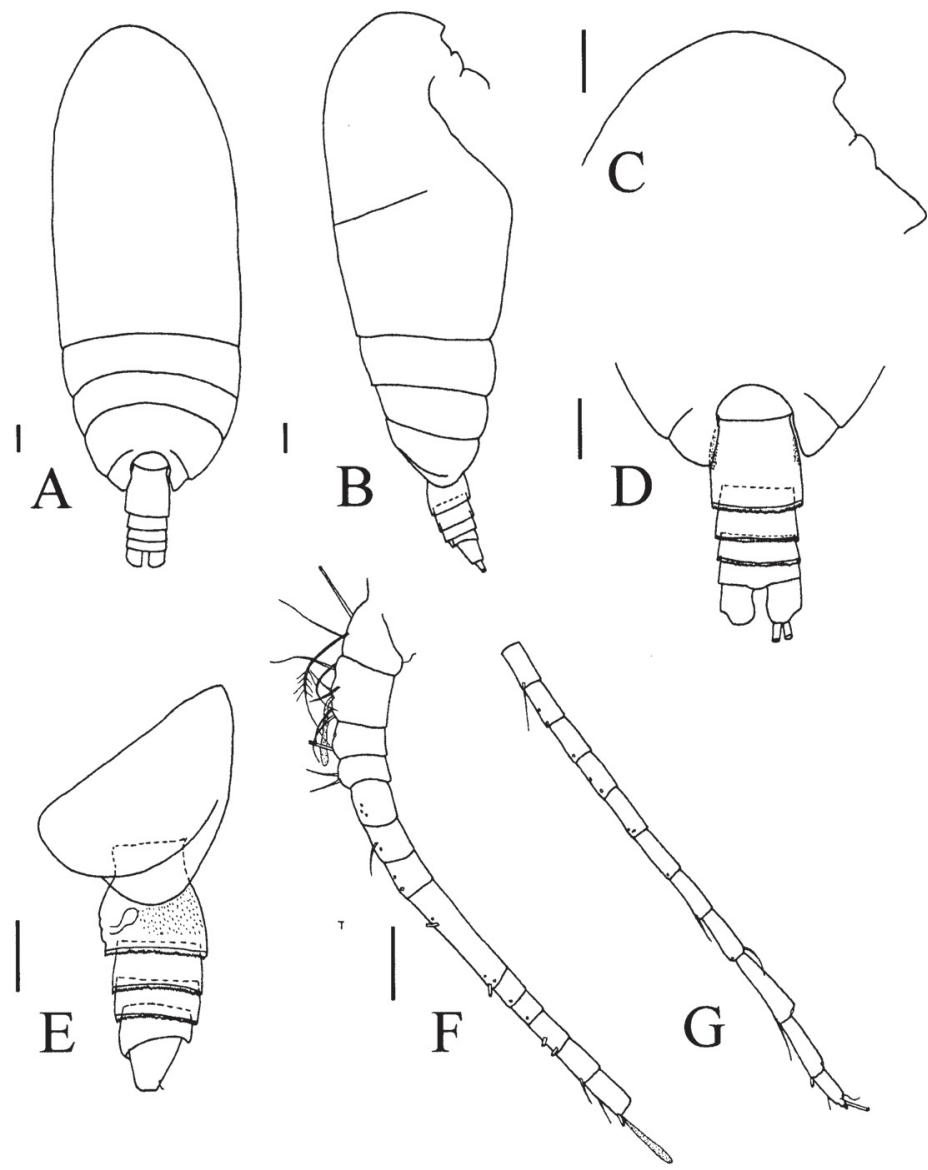

Fig. 20. Omorius atypicus gen.n., sp.n.,, :

A - habitus, dorsal; B - habitus, right lateral; C - anterior cephalosome, right lateral; D - posterior prosome and urosome, dorsal; E - posterior prosome and urosome, left lateral; F — antenna 1, articulating segments 1-13; G antenna 1, articulating segments 14-24. Scale lines $0.1 \mathrm{~mm}$.

Рис. 20. Omorius atypicus gen.n., sp.n.,

A - общий вид, вид со спины; В - общий вид, справа; C - передняя часть цефалосомы, справа; D - задняя часть просомы и уросома, со спины; $\mathrm{E}$ - задняя часть просомы и уросома, слева; $\mathrm{F}$ - антенна 1 , свободные сегменты 1-13; G - антенна 1, свободные сегменты 14-24. Масштаб 0,1 мм.

on the posterior face of the gnathobase of $\mathrm{Mn}$ is reported only for Byrathis, but it is present on Scolecithrix danae (unpublished observations of FDF), and may be much more widespread among the bradfordian genera than has been reported.

Etymology. The generic name "Omorius" honors copepodologist Makoto Omori for his contributions to the taxonomy of calanoid copepods. Gender masculine.

Type species: Omorius atypicus sp.n., by monotypy.

\section{Omorius atypicus sp.n.}

Figs. 20-23.

Specimens. Adult female holotype $1.57 \mathrm{~mm}$ (USNM \#1080965); prosome $1.28 \mathrm{~mm}$, urosome 0.29 $\mathrm{mm}$ from eastern tropical Pacific Ocean $1-5 \mathrm{~m}$ above Volcano 7, (dive 2146, D8, N8), 3022-3100m.

Habitus. Cephalosome and Pg1 fused dorsally, separate in lateral view; Pg4-5 fused dorsally, separate laterally; posterior corners of prosome as rounded lobes laterally (Fig. 20A, B, D-E); prosome 4.4 


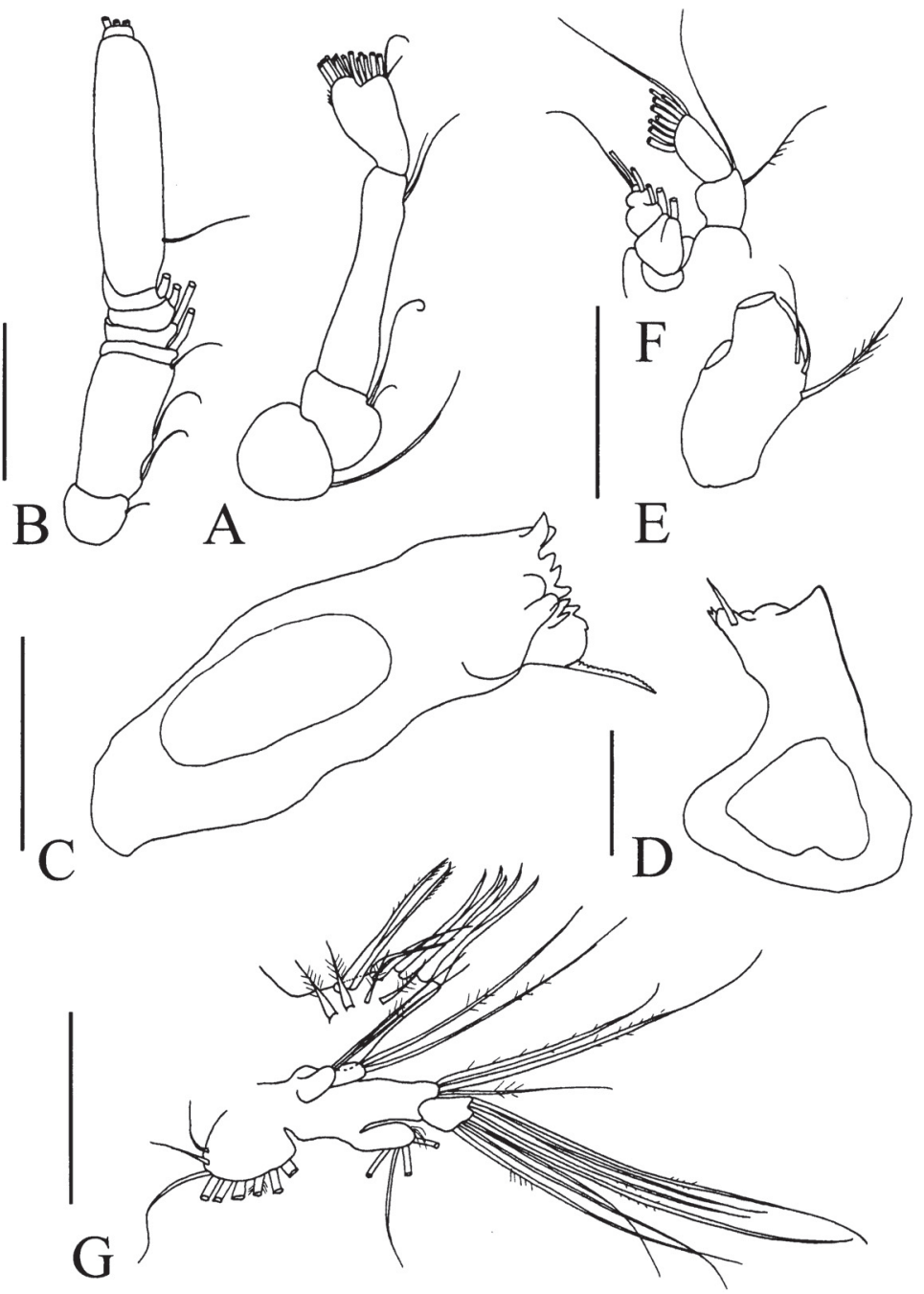

Fig. 21. Omorius atypicus gen.n., sp.n., + :

A - protopod and endopod of antenna 2; B - exopod of antenna 2; C - mandibular gnathobase, posterior; D mandibular gnathobase, proximal; E - basis of mandible; F - exopod and endopod of mandible; $\mathrm{G}$ - maxilla 1 . Scale lines $0.1 \mathrm{~mm}$.

Рис. 21. Omorius atypicus gen.n., sp.n., o+:

A - протоподит и эндоподит антенны 2; В - экзоподит антенны 2; C - гнатобаза мандибулы, задняя поверхность; D - гнатобаза мандибулы, проксимально; Е - базальный членик мандибулярного щупика; $\mathrm{F}$ экзоподит и эндоподит мандибулярного щупика; $\mathrm{G}$ - максилла 1. Масштаб 0,1 мм.

times longer than urosome. Genital complex with small spinules dorsally and laterally; distal part of spermathecae rounded (Fig. 20D-E).

Rostrum (Fig. 20C): without filaments.

A1 (Fig. 20F, G): 24 articulated segments; setation: $3,6+1,1+1$ ? , 2, 3?, 2?, 2?, 2+3?, 1?,1?, 2, 1, $2+1,1,2$ ?, 1?, 2?, 2?, 1?, 1, 1+1?, 1+1?, 1+1?, 4 .
A2 (Fig.21 A-B): coxa with 1 seta; basis with 2 setae. Ri 2-segmented; proximal segment with 2 setae, distal with 14 (6 terminal and 8 sub-terminal setae). Re 8-segmented with 1,3,1,1,1,1,1,3 setae.

Mn (Fig. 21C-F): gnathobase with tooth-like knob on posterior face and medial margin wide, proximally to distally, with 9 teeth, 1 seta; basis 


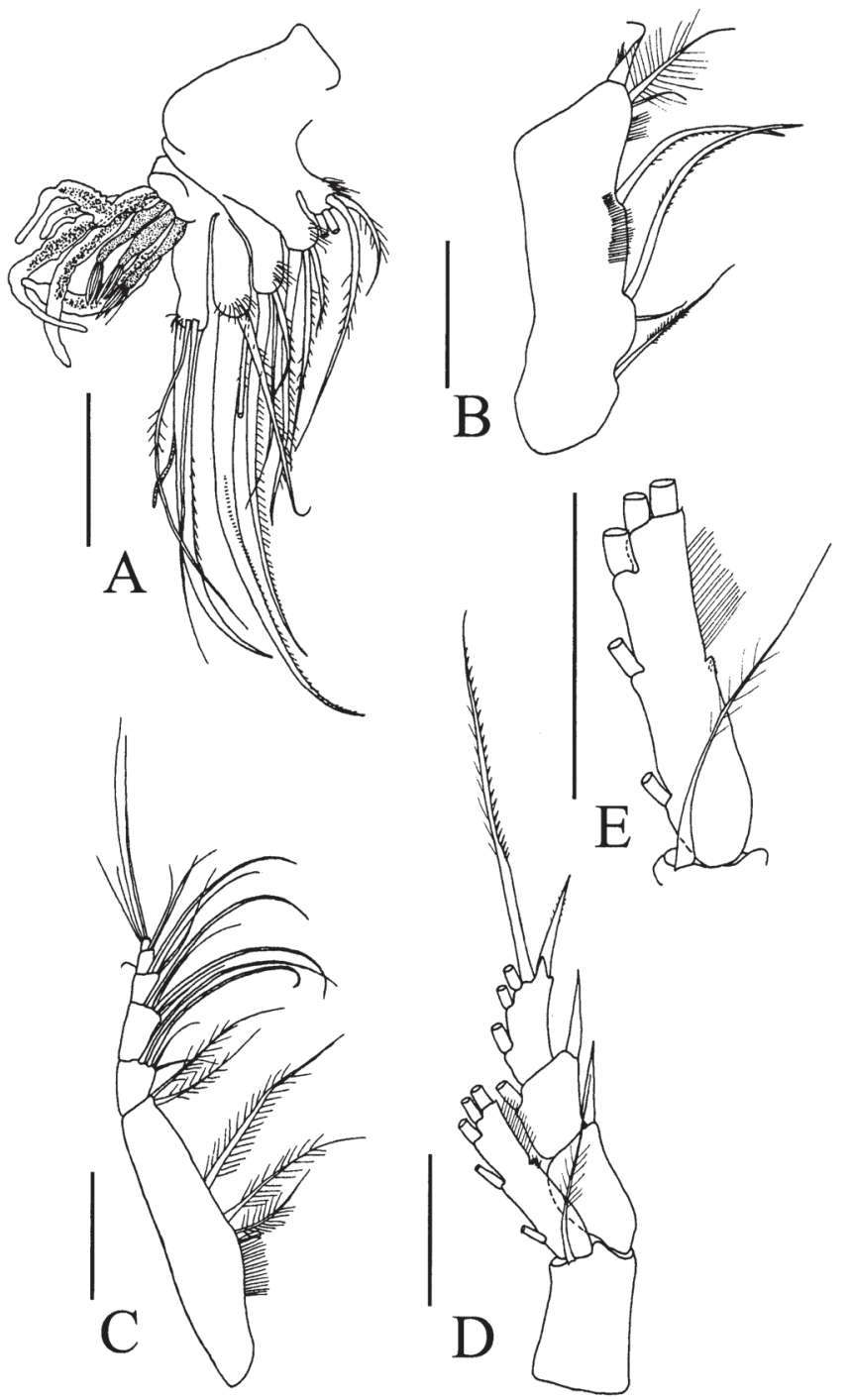

Fig. 22. Omorius atypicus gen.n., sp.n.,, :

A - maxilla 2; B - , syncoxa of maxilliped; C - basis and endopod of maxilliped; D — basis and rami of swimming leg 1, anterior; E - endopod of swimming leg 1, anterior. Scale lines $0.1 \mathrm{~mm}$.

Рис. 22. Omorius atypicus gen.n., sp.n.,

А - максилла 2; В - синкокса максиллипеды; C - базальный членик и эндоподит максиллипеды; D базальный членик и ветви первой пары плавательных ног, передняя поверхность; Е - эндоподит первой пары плавательных ног, передняя поверхность. Масштаб 0,1 мм.

with 3 setae. Ri 2-segmented, proximal segment with 2 setae, distal with 9 setae. Re with $1,1,1,1$, 2 setae.

Mx1 (Fig. 21G): praecoxal endite with 4 posterior setae and 9 terminal setae, $3^{\text {rd }}$ and $4^{\text {th }}\left(2^{\text {nd }}\right.$ and $3^{\text {rd }}$ from proximal seta) thin and slightly curved; coxal endite with 2 setae, coxal epipodite with 9 setae; proximal basal endite with 2 setae; distal basal endite with 3 setae; Ri articulating with basis, with groups of 2 and 5 setae; Re with 4 setae.

Mx2 (Fig. 22A): proximal praecoxal endite with 4 setae; distal with 3 setae, 1 thick. Proximal coxal endite with 3 setae, 1 thick, distal coxal endite with 3 setae, 1 thick. Proximal basal endite with 4 setae, 

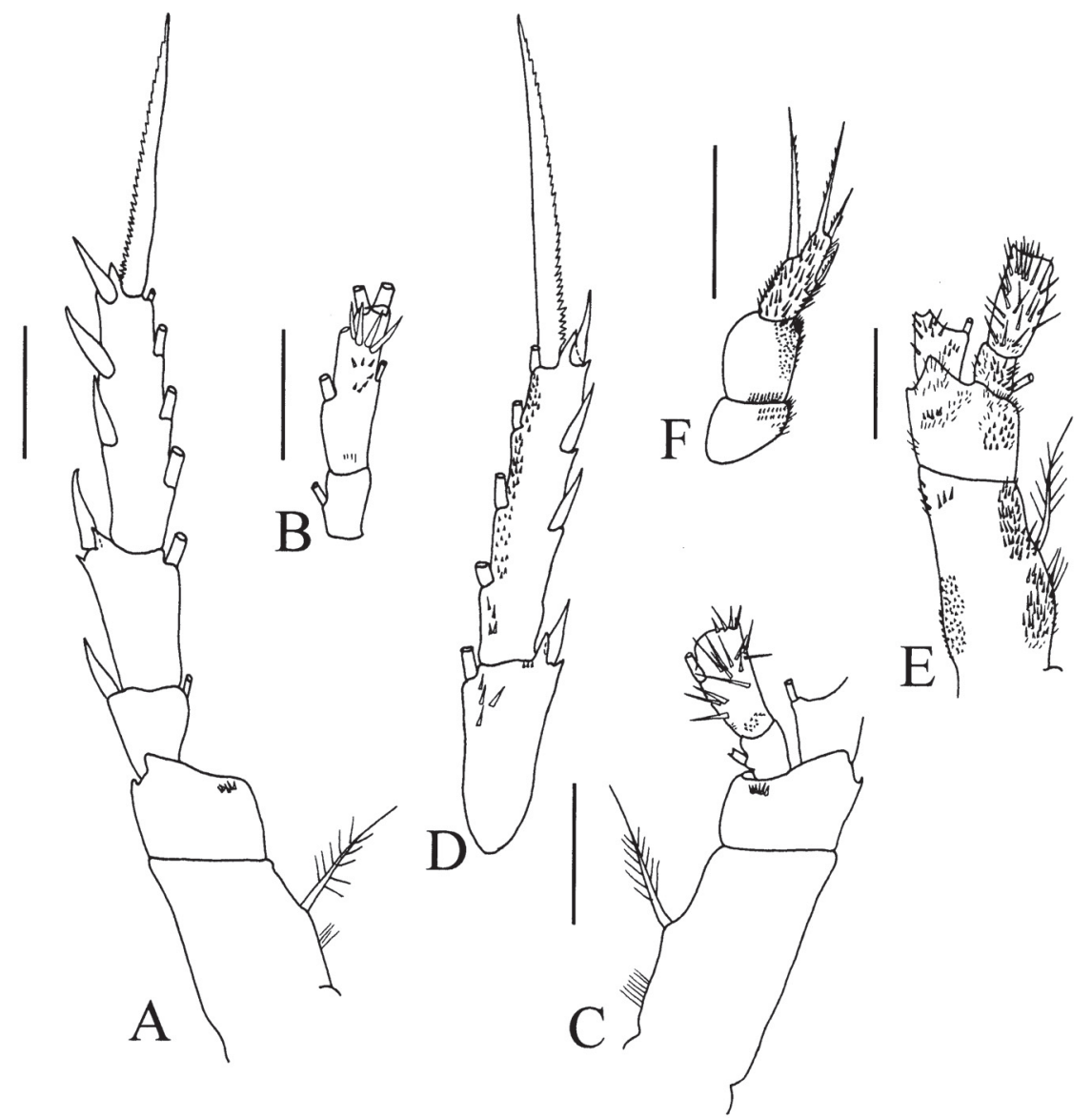

Fig. 23. Omorius atypicus gen.n., sp.n.,, :

A - coxa, basis and exopod of swimming leg 2, anterior; B - endopod of swimming leg 2, posterior; C — protopod, proximal exopodal segment, and proximal and middle endopodal segments of swimming leg 3 , posterior; D — middle and distal exopodal segments of swimming leg $3 ; \mathrm{E}$ - protopod, proximal exopodal segment, and proximal and middle endopodal segments of swimming leg 4, posterior; F, leg 5. Scale lines $0.1 \mathrm{~mm}$.

Рис. 23. Omorius atypicus gen.n., sp.n., ㅇ:

A - кокса, базальный членик и экзоподит второй пары плавательных ног, передняя поверхность; В - эндоподит второй пары плавательных ног, задняя поверхность; С - протоподит, проксимальный членик экзоподита и проксимальный и средний членики эндоподита третьей пары плавательных ног, задняя поверхность; D средний и дистальный членики экзоподита третьей пары плавательных ног; Е - протоподит, проксимальный членик экзоподита, и проксимальный и средний членики эндоподита четвертой пары плавательных ног, задняя поверхность; F - пятая пара ног. Масштаб 0,1 мм.

1 thick, 1 worm-like. Distal basal endite + Re with 5 worm-like and 3 brush-like setae.

Mxp (Fig. 22B-C): praecoxal endites of syncoxa with 1,2,1 sclerotized setae; coxal endite with 3 setae. Basis with a row of small denticles proximally, 3 medial setae, 2 setae on distal endite. Ri of 5 articulated segments with $4,4,3,3+1$ and 4 setae.

P1 (Fig. 22D-E): coxa without seta; basis with medial seta. Re 3-segmented, proximal with 1 later- al seta, middle with 1 medial and 1 lateral seta, distal with 3 medial, 1 terminal, 1 lateral seta; lateral seta of proximal segment extends beyond base of lateral seta of middle segment, lateral seta of middle segment extends beyond base of lateral seta of terminal segment. Ri 1-segmented, 3 medial and 2 terminal setae; Von Vaupel Klein's organ with seta of basis slightly curved, anterior knob of endopod with denticles and lateral denticles distally. 
P2 (Fig. 23A-B): coxa with medial seta; basis without seta, with a group of small denticles on posterior surface near distal medial edge. Re 3segmented, proximal segment with 1 medial and 1 lateral seta, middle with 1 medial and 1 lateral seta, distal with 4 medial, 1 terminal and 3 lateral setae. Ri 2-segmented, proximal segment with 1 medial seta, distal with 2 medial, 2 terminal and 1 lateral setae; distal segment with denticles on posterior surface, distal group with largest denticles.

P3 (Fig. 23C-D): coxa with medial seta; basis without seta, with a group of denticles. Re 3-segmented, proximal with 1 medial and 1 lateral seta, middle with 1 medial and 1 lateral seta, distal with 4 medial, 1 terminal and 3 lateral setae; middle and distal segments with denticles posteriorly. Ri 3segmented, proximal segment with 1 medial seta, middle segment with 1 medial seta and denticles posteriorly, distal segment missing.

P4 (Fig. 23E): coxa with medial seta; basis without seta; coxa and basis with denticles posteriorly. $\mathrm{Re}$ proximal segment with 1 medial and 1 lateral seta and denticles posteriorly, remaining part of ramus lost. Ri proximal segment with 1 medial seta, middle segment with 1 medial seta, distal segment lost; proximal and middle segments with denticles posteriorly.

P5 (Fig. 23 F): 3-segmented all with denticles posteriorly; distal segment (Re) with 1 long medial, 1 short lateral and 1 short subterminal setae and 1 terminal attenuation.

CR (Fig. 20D-E): 4 large, thick terminal setae, 1 small dorsal seta and 1 small medial ventral seta; terminal setae broken.

Etymology. The species epithet "atypicus" is given for atypical seta, which is heavily sclerotized, on the distal praecoxal endite of maxilliped.

\section{Rythabis Schulz, 1995}

Remarks. The genus Rythabis, described by Schulz in Schulz, Beckmann (1995), remains incompletely known. Indistinctly separated groups of setae on praecoxal endites of the syncoxa of the maxilliped appears to be the only synapomorphy shared by $R$. atlantica and the two new species described here. Two species have 6 worm-like and 2 brush-like setae on the distal basal endite + ramus of Mx2; 4 worm-like and 4 brush-like setae of the third species may be a secondarily derived condition. The praecoxal endites of the Mxp syncoxa bear 1, 2, 2 setae which is identical to many phaennid-like genera. One worm-like seta on the middle praecoxal endite and 1 brush-like seta on the distal praecoxal endite is a combination shared by Puchinia, Brachycalanus, Parkius and Plesioscolecithrix. The exopod of antenna 2 is 7 -segmented with only 1 seta on the elongate segment, similar to Parkius.

\section{Rythabis heptneri sp.n.}

Figs. 24-25.

Specimens. Adult female holotype (USNM \#1080966) $1.00 \mathrm{~mm}$ (excluding CR); prosome 0.78 $\mathrm{mm}$, urosome $0.22 \mathrm{~mm}$ (excluding $\mathrm{CR}$ ) from eastern tropical Pacific Ocean, near Kona, Island of Hawai; pipe sample taken at depth $600 \mathrm{~m}, 6$ July 1997.

Habitus (Fig. 24A). Adult female length 1.00 $\mathrm{mm}$ (CR lost); prosome 3.5 times longer than urosome. Cephalosome and Pg1, Pg4 and Pg5 separate; posterior corners of prosome rounded laterally (Fig. 24B); genital somite narrowing slightly at midlength (Fig. 24B, C); asymmetrical with bump on right slightly more pronounced than bump on left.

Rostrum (Figs. 24F, 25A): without filaments.

A1: broken.

A2 (Fig. 25B, C): coxa with 1 seta; basis with 2 setae. Ri 2-segmented, proximal segment with 1 seta, setae missing from distal segment. Only 4 segments retained on $\mathrm{Re}$, setae lost.

Mn (Fig. 25D, E): gnathobase with 6 teeth and 1 seta; basis with 2 setae. Ri 2-segmented, proximal segment with 2 setae, distal with 9 setae. Re with 1 , $1,1,1,2$ setae.

Mx1 (Fig. 25F): praecoxal endite with 10 terminal and 4 posterior setae; coxal endite with 4 setae, coxal epipodite with 9 setae; proximal basal endite with 4 setae; distal basal endite fused to Ri; setae of distal basal endite indistinguishable from those of Ri, 11 setae total. Re with 4 setae.

Mx2 (Fig. 25G): proximal praecoxal endite with 4 setae; distal with 3 setae, 1 recurved; proximal and distal coxal endite with 3 setae, 1 recurved on each endite; proximal basal endite with 4 setae, 1 thick, 1 worm-like. Distal basal endite + ramus with 4 wormlike and 4 brush-like ( 2 short, thick brush-like and 2 longer, thin brush-like) setae.

Mxp (Fig. 25H): setae on praecoxal endites of syncoxa not well-separated, with 1 (worm-like seta), 2 (1 worm-like seta), 2 (1 brush-like seta); coxal endite with 3 setae. Basis and Ri lost.

P1 (Fig. 25I): coxa without seta; basis with medial seta. Re 3-segmented, proximal with 1 lateral seta, middle with 1 medial and 1 lateral seta, distal with 3 medial, 1 terminal and 1 lateral setae; lateral seta on proximal segment does not extend beyond base of lateral seta of middle segment; lateral seta on middle segment extends beyond the base of lateral seta of terminal segment. Ri 1-segmented with 3 medial and 2 terminal setae; Von Vaupel Klein's organ with basal seta curved around anterior face of $\mathrm{Ri}$; Ri without anterior knob or denticles.

P2: coxa with medial seta; basis without seta, denticles on posterior surface of coxa and basis.

P3: coxa with medial seta; basis without seta; coxa and basis with denticles posteriorly. 

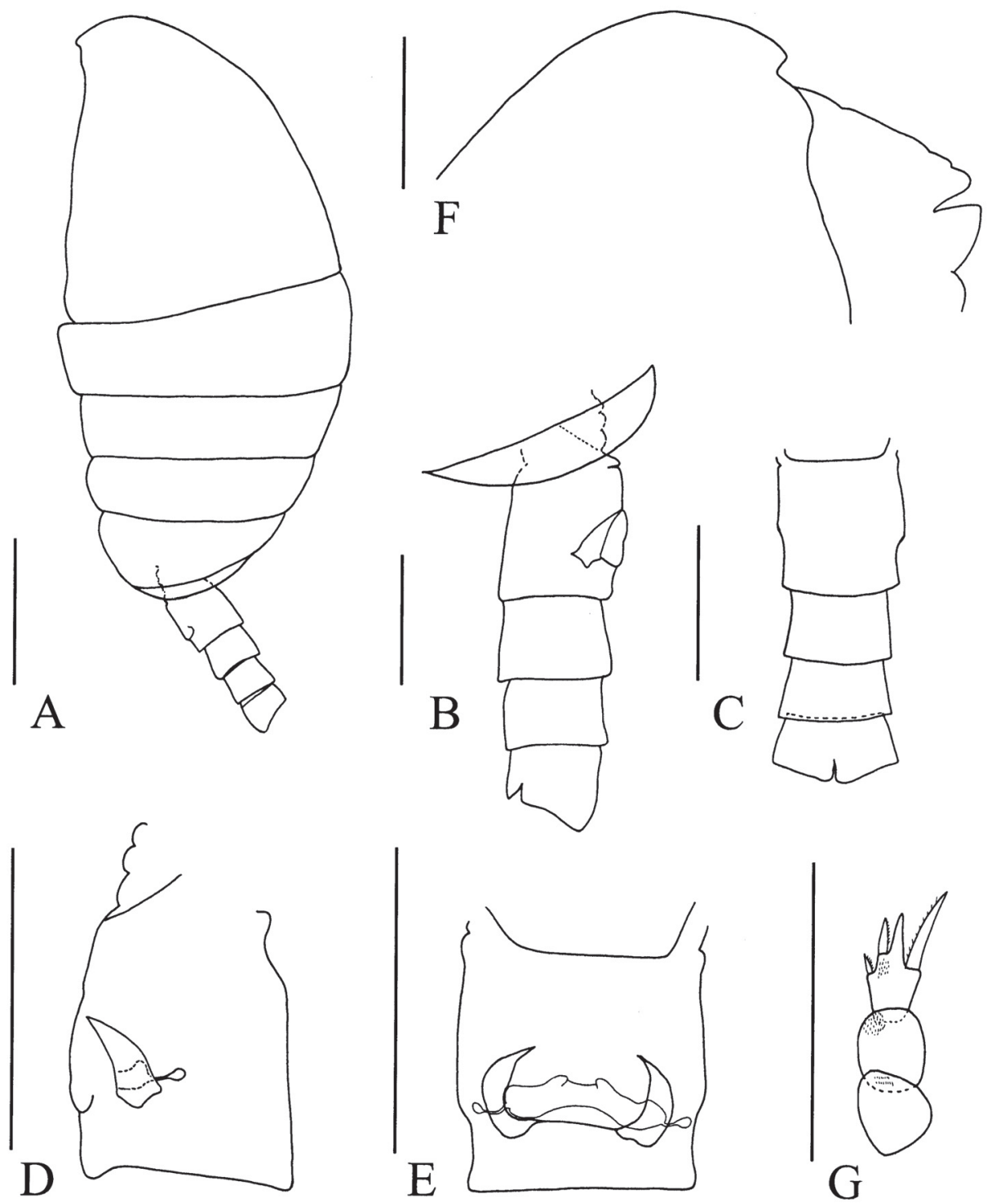

Fig. 24. Rythabis heptneri sp.n.,, :

A - habitus, left lateral; B - posterior prosome and urosome, right lateral; C - urosome, dorsal; D - genital complex, left lateral; E - genital complex, ventral; F — anterior cephalosome, left lateral; G - leg 5, posterior. Scale lines $0.1 \mathrm{~mm}$

Рис. 24. Rythabis heptneri sp.n., ㅇ:

$\mathrm{A}$ - общий вид слева; В - задняя часть просомы и уросома, справа; C - уросома, вид со спины; D генитальный комплекс слева; Е - генитальный комплекс, вид с брюшной стороны; $\mathrm{F}$ - передняя часть цефалосомы слева; $\mathrm{G}$ - пятая пара ног, задняя поверхность. Масштаб 0,1 мм. 


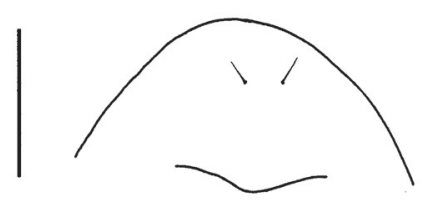

A
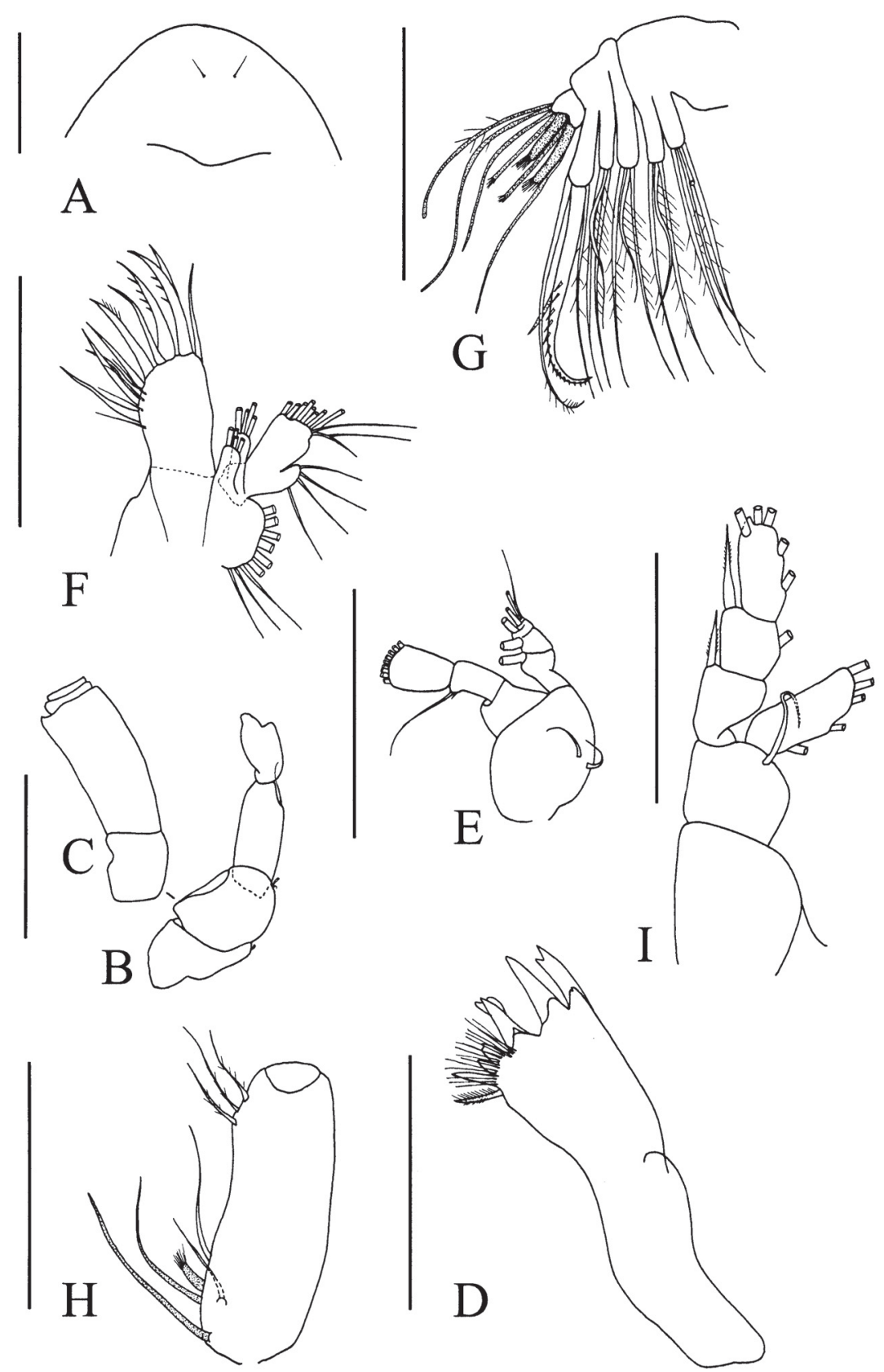

Fig. 25. Rythabis heptneri sp.n.,, :

A - anterior cephalosome, ventral; B - protopod and endopod of antenna 2; C - exopod of antenna 2, 4 proximal segments; D - mandibular gnathobase, posterior; $\mathrm{E}$ - mandibular palp; $\mathrm{F}$ - maxilla 1; $\mathrm{G}$ - maxilla 2; $\mathrm{H}$ - syncoxa of maxilliped; I - swimming leg 1, anterior. Scale lines $0.1 \mathrm{~mm}$.

Рис. 25. Rythabis heptneri sp.n.,, :

A - передняя часть цефалосомы, вид с брюшной стороны; В — протоподит и эндоподит антенны $2 ; \mathrm{C}-$ экзоподит антенны 2; D — гнатобаза мандибулы, задняя поверхность; Е - щупик мандибулы; F — максилла 1; $\mathrm{G}$ - максилла 2; H - синкокса максиллипеды; I - первая пара плавательных ног, передняя поверхность. Масштаб 0,1 мм. 
P4: coxa with medial seta; basis without seta; coxa and basis with denticles posteriorly.

P5 (Fig. 24G): 3-segmented; distal segment (Re) with 1 long medial, 1 short lateral and 1 short subterminal setae, and 1 terminal attenuation.

CR: missing.

Etymology. The species name "heptneri" honors copepodologist Mikhail Vladimirovich Heptner for his contributions to the taxonomy of calanoid copepods. Gender masculine.

Remarks. Rythabis heptneri differs from $R$. atlantica and $R$. schulzi as follows: distal basal endite + ramus of $\mathrm{Mx} 2$ with 4 worm-like and 4 brush-like setae (6 worm-like setae and 2 brush-like setae in $R$. atlantica and $R$. schulzi); Mx1 with 11 setae on basis + Ri (17 in R. atlantica, 13 in R. schulzi); basis of Mx1 fused to Ri (separate in R. atlantica); and basal seta of P1 strongly curved around anterior face of endopod (curved over the anterior knob on endopod of $R$. atlantica).

\section{Rythabis schulzi sp.n.}

Figs. 26-28.

Specimens. Adult female holotype $1.35 \mathrm{~mm}$ (USNM \#1080967); prosome $0.99 \mathrm{~mm}$, urosome 0.36 $\mathrm{mm}$, from eastern tropical Pacific Ocean 1-5 m above Volcano 7, (dive 2146, D8, N4), depth 3022-3100 m.

Habitus. Adult female length $1.35 \mathrm{~mm}$. Prosome 2.75 times longer than urosome. Cephalosome and $\mathrm{Pg} 1$ separate; $\mathrm{Pg} 4$ and $\mathrm{Pg} 5$ separate; posterior corners of prosome rounded laterally. Genital complex symmetrical in ventral view (Fig. 26C); with a ventral anterior and posterior bump in lateral view (Fig. 26A, B).

A1: 24 articulating segments.

A2: coxa with 1 seta; basis with 2 setae. Ri 2segmented, proximal segment with 1 setae, distal segment with 7 setae on subterminal lobe. Re 7 segmented with $1,1,1,1,1,1,3$ setae.

Mn: gnathobase with 6 well-incised teeth and a seta; basis with 2 setae. Ri 2-segmented, proximal segment with 2 setae, distal with 9 setae. Re with 1 , $1,1,1,2$ setae.

Mx1 (Fig. 28A): praecoxal endite with 9 terminal and 4 posterior setae; coxal endite with 5 setae, coxal epipodite with 9 setae; proximal basal endite with 4 setae; distal basal endite fused to $\mathrm{Ri}$ with groups of 4 and 9 setae. Re with 5 setae.

Mx2 (Fig. 27A-B): proximal praecoxal endite with 4 setae; distal with 3 setae. Proximal coxal endite with 3 setae, distal with 3 setae. Proximal basal endite with 4 setae, 1 thick and straight, and 1 worm-like. Distal basal endite + ramus with 6 worm-like setae (3 shorter and 3 longer) and 2 brush-like setae.

Mxp (Fig. 27C-D): syncoxa with several areas of denticles anteriorly; groups of setae on praecoxal endites of syncoxa not well-separated, with 1 (worm- like seta), 2 (1 worm-like seta), 2 (1 brush-like seta); coxal endite with 3 setae. Basis with 3 setae in the middle and 2 setae distally. Ri with 4, 4, 3, 3+1 and 4 setae.

P1 (Fig. 28B-C): coxa without seta; basis with medial seta. Re 3-segmented, proximal segment with 1 lateral seta, middle segment with 1 lateral seta and 1 medial seta; distal segment with 2 lateral, 1 terminal and 3 medial setae; lateral seta of proximal segment extends well beyond base of lateral seta of middle segment; lateral setae of middle segment extends well beyond base of lateral seta of distal segment. Ri 1-segmented with 3 medial and 2 terminal setae; organ of Von Vaupel Klein as curved basal seta and anterior knob of endopod with proximal denticles.

P2: coxa with medial seta; basis without seta, denticles on posterior surface of coxa and basis. Re 3 -segmented, proximal with 1 medial and 1 lateral seta, middle with 1 medial and 1 lateral seta, distal with 4 medial, 1 terminal and 3 lateral setae; middle and distal segments with denticles posteriorly. Ri 2segmented, proximal with 1 medial seta, distal with 2 medial, 2 terminal and 1 lateral setae; both segments with denticles on posterior surface.

P3 (Fig. 28D): coxa with medial seta; basis without seta; coxa and basis with denticles posteriorly. Re 3 -segmented, proximal segment with 1 medial and 1 lateral seta, middle with 1 medial and 1 lateral seta, distal with 4 medial, 1 terminal and 3 lateral setae; distal segment with denticles posteriorly. Ri proximal segment with 1 medial seta, middle segment with 1 medial seta, distal with 1 lateral, 2 terminal and 2 medial setae; all segments with denticles posteriorly.

P4 (Fig. 28E): coxa with medial seta; basis without seta; coxa and basis with denticles posteriorly. Re 3 -segmented, proximal segment with 1 medial and 1 lateral seta, middle with 1 medial and 1 lateral seta, distal with 4 medial, 1 terminal and 3 lateral setae; all segments with denticles posteriorly. Ri proximal segment with 1 medial seta, middle segment with 1 medial seta, distal with 1 lateral, 2 terminal and 2 medial setae; all segments with denticles posteriorly.

P5 (Fig. 28F): 3-segmented, distal segment (Re) with 1 long medial, 1 shorter lateral and 1 long subterminal seta and an unarticulated attenuation.

CR: 4 large, thick terminal setae, 1 small dorsal seta and 1 small medial ventral seta; terminal setae broken.

Etymology. The species name "schulzi" honors copepodologist Knud Schulz for his contributions to the taxonomy of calanoid copepods. Gender masculine.

Remarks. In the available specimen of Rythabis schulzi, the left A1 is missing; right nearly as long as prosome and identical to A1 of $R$. atlantica. Rythabis schulzi differs in the following characters from $R$. atlantica and $R$. heptneri: Mx1 distal basal 

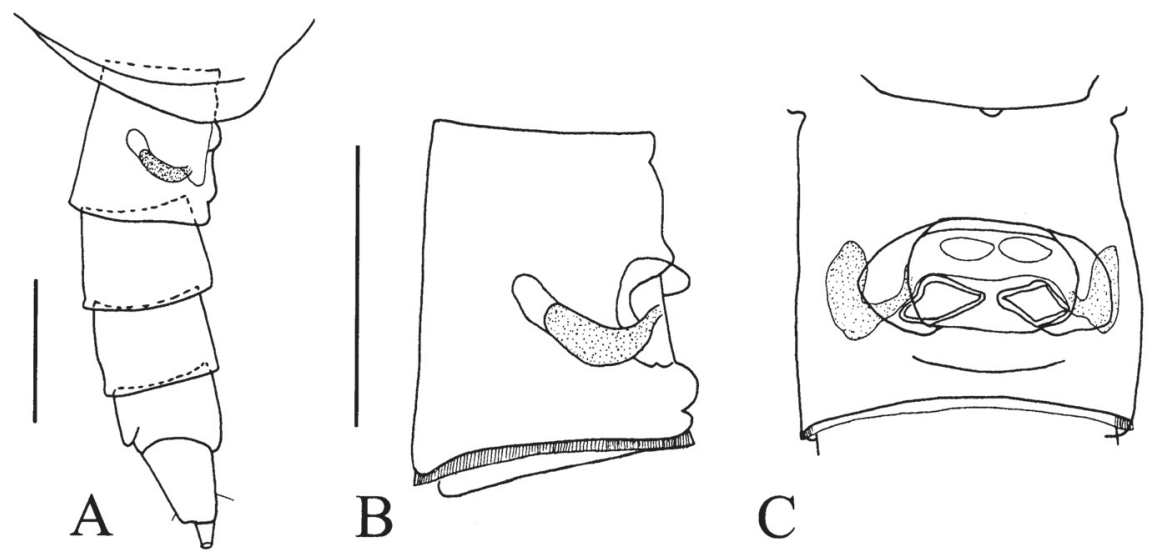

Fig. 26. Rythabis schulzi sp.n., ㅇ:

A - posterior prosome and urosome, right lateral; B — genital complex, right lateral; C - genital complex, ventral. Scale lines $0.1 \mathrm{~mm}$.

Puc. 26. Rythabis schulzi sp.n.,, :

A - задняя часть просомы и уросома справа; В — генитальный комплекс справа; C - генитальный комплекс с брюшной стороны. Масштаб 0,1 мм.

endite plus Ri with 13 setae (17 setae on $R$. atlanti$c a, 11$ on $R$. heptneri); P1 lateral setae of proximal and middle segments extending beyond base of lateral seta of middle and lateral seta of distal segment, respectively, ( $R$. atlantica not true for either seta; $R$. heptneri not true for lateral seta of proximal segment). Rythabis schulzi differs in the following characters from $R$. atlantica: Mx1 exopod with 5 setae (4 setae in $R$. atlantica); Ri fused to basis (separate in R. atlantica). Rythabis schulzi differs in the following characters from $R$. heptneri: distal basal endite + ramus of Mx 2 with 6 worm-like setae and 2 brush-like setae (4 worm-like and 4 brushlike setae on $R$. heptneri); P1 seta of basis less curved than in $R$. heptneri; endopod with denticles (R. heptneri without denticles).

\section{Discussion}

Calanoid copepods belonging to bradfordian genera possess two kinds of poorly-sclerotized, chemosensory setae on the distal endite of the basis and ramus of maxilla 2; many species also have such setae on the praecoxal endites of the maxilliped. Most bradfordian species are members of the Scolecitrichidae (about 200 nom- inal species in 25 genera) or the Phaennidae (about 110 nominal species in eight genera), and most of these species are pelagic. Species of Tharybidae (about 50 nominal species in five genera), Diaixidae (about 10 nominal species in two genera) and Parkiidae (one species in one genus) have been collected in waters immediately above the sea bed. Giesbrecht (1892) diagnosed the first of these families, Scolecitrichidae. When Diaixidae, Phaennidae and Tharybidae were established, Sars (1902) placed Scolecitrichidae and Phaennidae in a different taxonomic section than Diaixidae and Tharybidae, implying two separate monophyletic lineages for calanoids with these chemosensory setae. Fleminger (1957) proposed the four families were closely related, in part based on the chemosensory setae. However, Fleminger also noted that it was difficult to separate species of Scolecitrichidae from those of Tharybidae, and recent attempts at family placement of Cenognatha, Neoscolecithrix, Rythabis and Xantharus exemplify the problem (Table 3). More recently, Andronov (2002) questioned the validity of both 


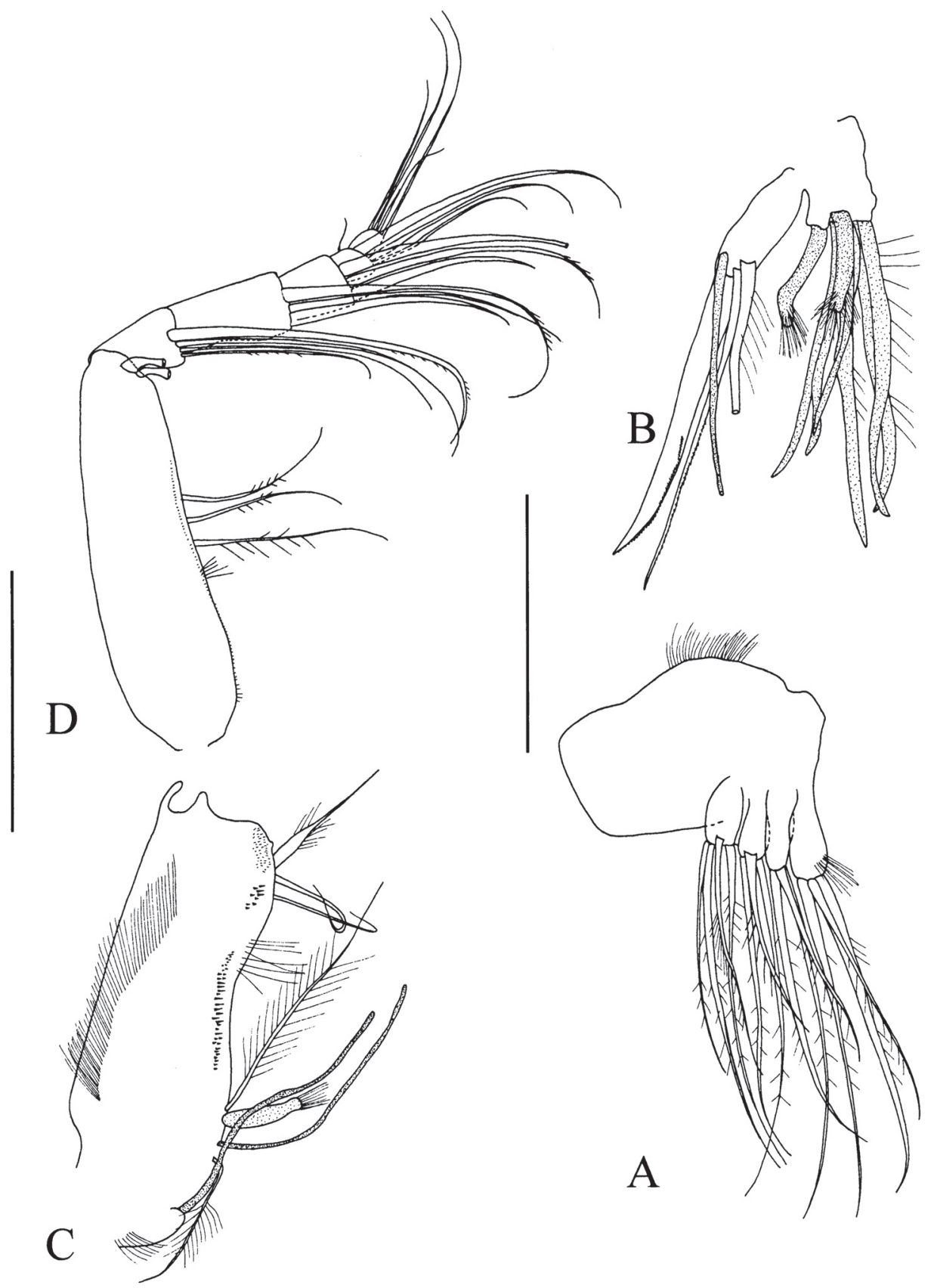

Fig. 27. Rythabis schulzi sp.n., ㅇ:

A - praecoxa and coxa of maxilla 2; B - basis and ramus of maxilla 2; C - syncoxa of maxilliped; D - basis and endopod of maxilliped. Scale lines $0.1 \mathrm{~mm}$.

Рис. 27. Rythabis schulzi sp.n.,

A - прекокса и кокса максиллы 2; В - базальный эндит и ветвь максиллы 2; C - синкокса максиллипеды; $\mathrm{D}$ - базальный членик и эндоподит максиллипеды. Масштаб 0,1 мм. 

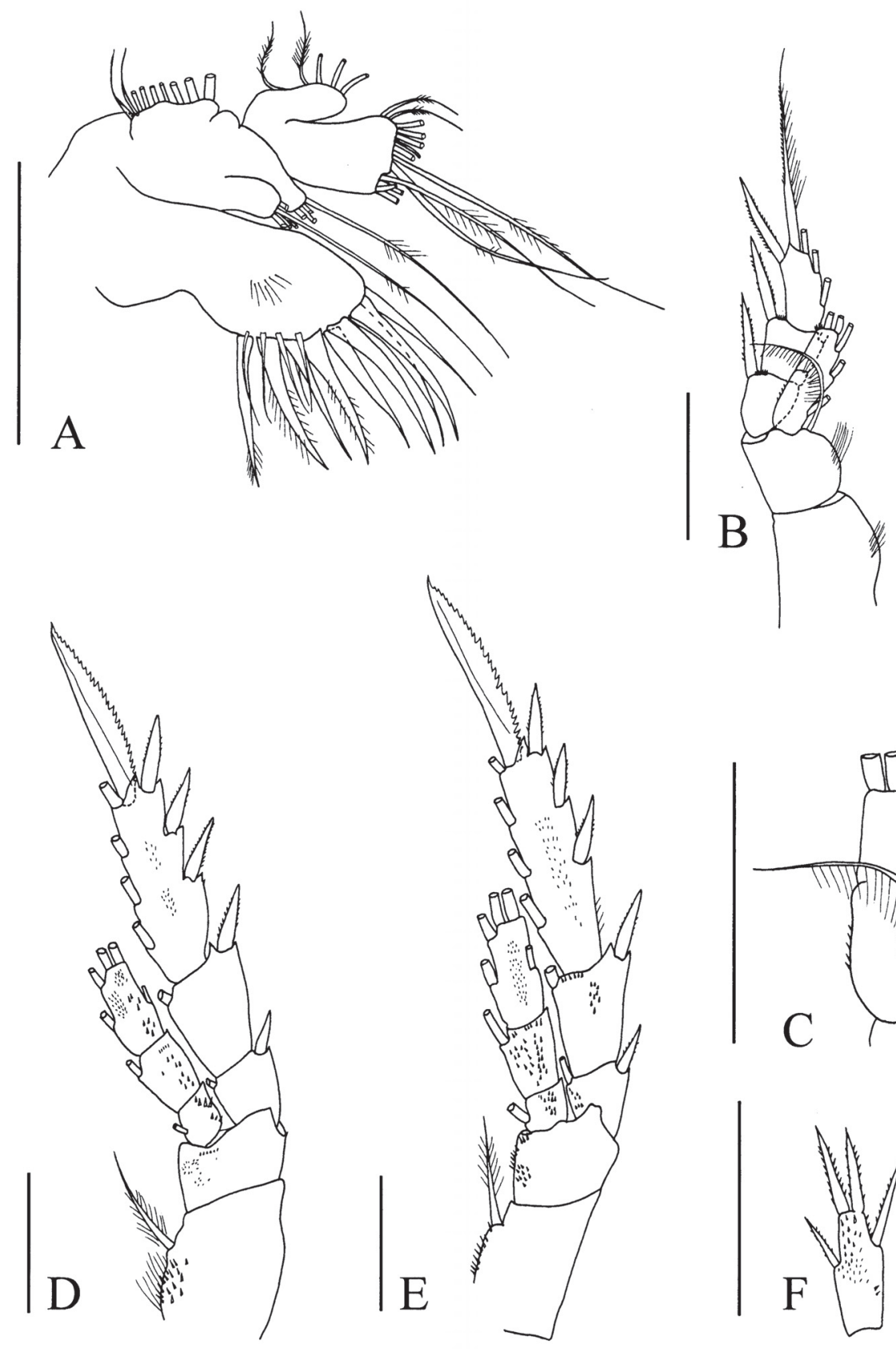

Fig. 28. Rythabis schulzi sp.n., ㅇ:

A - maxilla 1; B - swimming leg 1, anterior; C - distal section of basis and endopod of swimming leg 1, anterior; D — swimming leg 3, posterior; E — swimming leg 4; F — distal segment, exopod of leg 5. Scale lines $0.1 \mathrm{~mm}$. Рис. 28. Rythabis schulzi sp.n.,, :

A - максилла 1; В - первая пара плавательных ног, передняя поверхность; С - дистальная часть базального членика и эндоподит первой пары плавательных ног, передняя поверхность; D - третья пара плавательных ног, задняя поверхность; Е — четвертая пара плавательных ног; F — дистальный сегмент, экзоподит пятой пары ног. Масштаб 0,1 мм. 
Tharybidae and Diaixidae: "Attempts to determine unique diagnostic characters for Diaixidae and Tharybidae, that were absent in Scolecithrichide (sic), proved unsuccessful; the existing diagnostic characters of the two former families are not sufficient to separate them from Scolecithrichide (sic)" (Andronov, 2002: 2). In the same publication, he elaborated: "Recently conducted researches of Diaixidae repre-sentatives (Grice, Hulsemann, 1970; Andronov, 1979, present publication) demonstrated that nearly all their characters (i.e. of diaixids) are also found in family Scolecitrichidae (see, for example, Scolecitrichidae definition in Bradford (1973). This concerns also partial reduction of some oral parts in males of some species, and presence of typical to Scolecitrichidae composition of modified sensory setae on females Mx2 (3 worm-like, 5 brushlike). Other distinguishing characters are also found in this or that species of later family, excluding, probably, relatively large male P5, typical for Diaixis species (but this is qualitative character). Anawekia species so slightly differ from Diaixis species, especially in peculiar morphological characters of males' specialized P5, that, probably, in future these genera will be considered synonymous." (Andronov, 2002: 910 , translated from the Russian).

With an increasing number of surveys of the deep-sea and particularly of waters immediately above the deep-sea floor, number of species with morphologically diverse chemosensory setae has increased significantly, resulting in several new taxa (Andronov, 1981; Park, 1983a; Vyshkvartzeva, 1989b, 2000, 2001; Schulz, Beckmann, 1995; Ferrari, Markhaseva, 1996; Ferrari, Markhaseva, 2000b, c; Vyshkvartzeva, 2000; Bradford-Grieve, 2001; Vyshkvartzeva, 2001; Markhaseva, 2002; Markhaseva, Schnack-Schiel, 2003; Markhaseva, Dahms, 2004). The most recent bradfordian family, Parkiidae was considered monotypic at the time of the discovery of Parkius karenwishneri Ferrari and Markhaseva, 1996; the diagnosis was based on setation patterns of maxilla 2 and the maxilliped, and the epicuticular extensions of Von Vaupel Klein's organ. The four other bradfordian families continue to be diag- nosed using incomplete analyses of the number and morphology of the chemosensory setae on maxilla 2 (Bradford et al., 1983, Boxshall, Halsey, 2004). Observations of these transformed setae on maxilla 2 do not permit assignment of particular setae to the distal endite of the basis or to the presumably multi-segmented ramus, so that homologous setae cannot be identified among different species. This problem of setal homologues on maxilla 2 presents a significant obstacle to the analysis of bradfordian species. Recently, Ferrari and Markhaseva (2005) show that within the genus Tharybis, the number and kinds of sensory setae on the distal basal endite plus ramus of maxilla 2 exhibits the following: 3 worm-like setae, 5 brush-like setae and 1 sclerotized; 3 worm-like setae and 6 brush-like setae; 3 worm-like setae and 5 brush-like setae. This variability further suggests that the number and kinds of sensory setae on the distal basal endite plus ramus of maxilla 2 alone is not adequate to diagnose the bradfordian families, or to separate bradfordian genera with similar numbers and kinds of sensory setae (Ferrari and Markhaseva, 2000c: 1087).

Misplaced emphasis on the chemosensory setae of maxilla 2 in diagnoses of bradfordian families and the underexploration of waters immediately above the deep-sea floor have compromised contemporary understanding of relationships among their constituent genera. In the following analysis, two other characters are considered to have affected the evolution of bradfordian families: number and morphology of the setae on the praecoxal endites of the maxilliped; setation and arthrodial membranes on the exopod of antenna 2. The following is an analysis of these characters.

The loss and/or transformation of setae to the praecoxal endites of syncoxa of the maxilliped recently has been suggested as important to the evolutionary history of the bradfordian families (Ferrari, Markhaseva, 2000c: 1087). Earlier, Ohtsuka et al. (1998: 801) did not consider this character diagnostically useful: "Since the number and structure of sensory setae on the Mxp syncoxa vary among congeners, these are not regarded as a diagnostic character"; nor 
Table 3. Family placement of Cenognatha, Neoscolecithrix, Rythabis and Xantharus in recent publica-

Таблица 3. Систематическое положение родов Cenognatha, Neoscolecithrix, Rythabis и Xantharus в публикациях последних лет.

\begin{tabular}{|l|c|c|c|c|c|}
\hline & Original placement & $\begin{array}{c}\text { Bradford-Grieve } \\
2001,2004\end{array}$ & $\begin{array}{c}\text { Vyshkvartzeva } \\
2000,2001\end{array}$ & $\begin{array}{c}\text { Ohtsuka, Box shall } \\
\& \text { Fos shagen 2003 }\end{array}$ & $\begin{array}{c}\text { Boxshall \& } \\
\text { Halsey 2004 }\end{array}$ \\
\hline Cenognatha & $\begin{array}{c}\text { Bradford-Grieve } \\
\text { 2001: Tharybidae }\end{array}$ & Tharybidae & - & Scolecitrichidae & Scolecitrichidae \\
\hline Neoscolecithrix & $\begin{array}{c}\text { Canu 1896: not } \\
\text { assigned to family }\end{array}$ & Tharybidae & Scolecitrichidae & Scolecitrichidae & Scolecitrichidae \\
\hline Rythabis & $\begin{array}{c}\text { Schulz, Beckmann } \\
\text { 1995: Tharybidae }\end{array}$ & Tharybidae & - & Scolecitrichidae & Scolecitrichidae \\
\hline Xantharus & $\begin{array}{c}\text { Andronov 1981: } \\
\text { Phaennidae }\end{array}$ & Tharybidae & Scolecitrichidae & Scolecitrichidae & Scolecitrichidae \\
\hline
\end{tabular}

did Vyshkvartzeva (2000: 237) consider its value for diagnoses: "Hence, in contrast to the permanent composition of the sensory setae on the distal segments of Mx2 endopod, the number of sensory setae on the Mxp protopod cannot be used as a diagnostic character in Scolecitrichidae and some other Bradfordian families". However, Ohtsuka et al. (2003: 62) mentioned the setation of the third syncoxal endite (our distal praecoxal endite) in defining the Scolecitrichidae with "third syncoxal endite of Mxp represented by a single setal element, usually a brush-like sensoriform setae". Assignment of setae to each of the three praecoxal endites usually is unequivocal except for species of Rythabis in which assignment of setae to endites are problematical because all setae on these endites appear to originate close to the proximal arthrodial membrane.

The ancestral bradfordian calanoid is assumed to have had 1, 2, and 3 sclerotized, mechanosensory setae on the proximal, middle and distal praecoxal endites, respectively of the syncoxa of the maxilliped (Fig. 29C) (Vaupel Klein, Rijerkerk, 1997). The first transformation to the praecoxal endites is assumed to have been the loss of one sclerotized seta from the distal endite (Fig. 29D), and the second transformation is assumed to have been the loss of a second sclerotized seta from that endite (Fig.
29E). Here, loss of a sclerotized seta is equivalent to a single transformation. Subsequently, one sclerotized seta on each of the three endites may be transformed into to a worm-like, chemosensory seta. A brush-like seta, often present on the distal endite, is assumed to be derived from a worm-like seta (Ohtsuka et al., 1998), rather than directly from a sclerotized seta, so that presence of a brush-like seta represents two transformations.

The exopod of antenna 2 of the ancestral bradfordian calanoid (Fig. 30A) is assumed to have had a proximal segment with a medial seta, followed by a long segment with three medial setae arranged linearly. Four short segments each with one long, thick seta were followed by an elongate segment with its medial seta at mid-length. A small, distal segment with three terminal setae completes the ramus. This exopod is assumed to have been derived from a 10-segmented exopod of the ancestral calanoid; nine segments, each with a single medial seta and of similar size, was followed by a distal segment with three terminal setae (see Ferrari and Markhaseva (2000a)). Here, the long segment with three medial setae of the bradfordian ancestor is assumed to be a complex of three segments; each represented by its medial seta but two lack a distal arthrodial membrane. The exopod of antenna 2 of calanoids is patterned 
during the naupliar phase of development from an area immediately distal to the proximal segment so that the proximal seta of the long segment is the last structure formed (unpublished observations of nauplii of Calanus finmarchicus (Gunnerus, 1770)). A proximal-to-distal loss of setae on the long segment, followed by loss of the arthrodial membrane between the long segment and the proximal of the four small segments, is assumed here to represent the progessive transformation of the exopod affected simply by a progressively earlier truncation of development. From this model, an exopod for which a medial seta is absent from the proximal
1

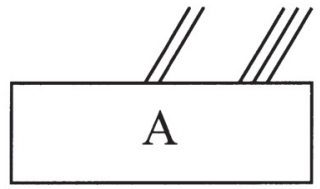

0

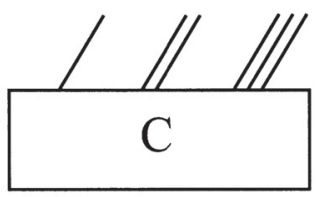

1

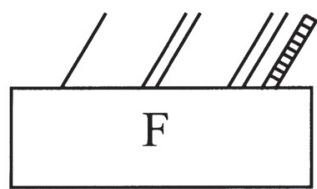

2
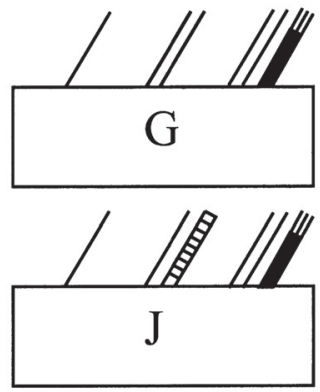

3

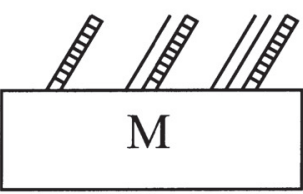

4
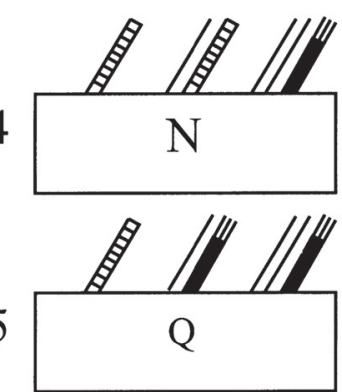

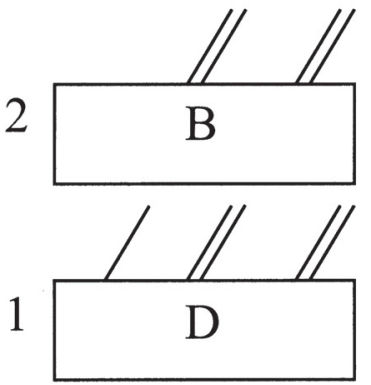

2

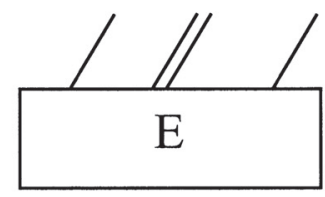

3

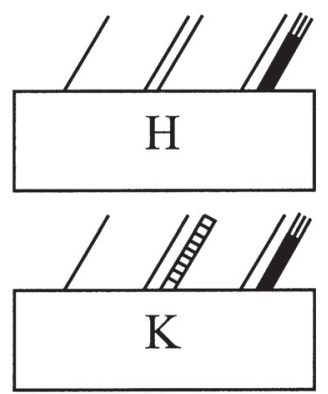

4

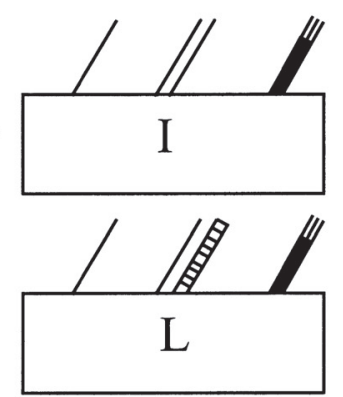

5

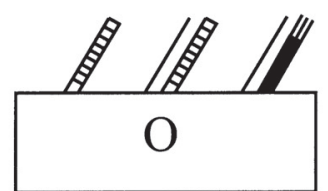

6

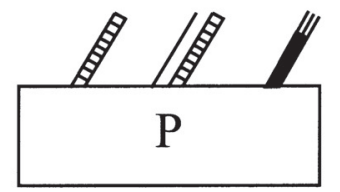


segment is the first derived state, followed by one in which the proximal seta of the long segment complex fails to form (Fig. 30B), and then a long segment complex in which the proximal and middle setae fail to form (Fig. 30C). Further transformations are a long segment complex in which no setae are present (Fig. 30E), or one in which the distal arthrodial membrane of the long segment complex fails to form (Fig. 30D), and finally a long segment on which both distal seta and distal arthrodial membrane fail to form so that the long segment is composed of four segments with one distal seta.

The ancestral bradfordian calanoid is assumed to have had nine setae on the distal endite of the basis plus ramus of maxilla 2 (Ferrari, Markhaseva, 2000, Vyshkvartzeva, 2001, Ohtsuka et al., 2003) because no more than nine sclerotized setae are present on any species in the superfamily Clausocalanoidea (Park, 1978; Vaupel Klein, Rijerkerk, 1997; Schulz, Markhaseva, 2000) (Table 4). Following the transformation series proposed for syncoxal setae of the maxilliped (above), 1 sclerotized seta plus five worm-like setae and 3 brushlike setae on the distal endite of the basis plus ramus of maxilla 2, as is present in Neoscolecithrix japonica Ohtsuka, Boxshall, Fosshagen, 2003, represents 11 transformations among the nine originally sclerotized setae, and is the least

Fig. 29. Ancestral condition of setation of praecoxal endites of the maxilliped syncoxa for various bradfordian genera (source of observations in brackets):

A-Brodskius (here); B - Undinella (von Vaupel Klein, 1970); C - Grievella (Ferrari, Markhaseva, 2000c), Tharybis (Ferrari, Markhaseva, 2005); D - Phaennocalanus (Markhaseva, 2002); E - Archescolecithrix (Vyshkvartzeva, 1989a), Omorius (here); F - Byrathis (here); G - Falsilandrumius (Vyshkvartzeva, 2001), Xantharus (Schulz 1998); H, Cephalophanes (Park, 1983b), Cornucalanus (Park, 1983b), Onchocalanus (Park, 1983b), Phaenna (Park, 1983b), Talacalanus (Park 1983b for Xanthocalanus greeni), Xanthocalanus (Markhaseva, 1998); I - Amallothrix (Park, 1970 for Scolecithricella lobophora), Lophothrix (Park, 1983a), Mixtocalanus (Vyshkvartzeva, 1989a), Racovitzanus (Park, 1983a), Scopalatum (Ferrari, Steinberg, 1993); J - Cenognatha (Hulsemann, 1985), Neoscolecithrix (BradfordGrieve, 2001); K - Plesioscolecithrix (Markhaseva, Dahms, 2004); L — Parascaphocalanus (Vyshkvartzeva, 2001), Scolecitrichopsis (Vyshkvartzeva, 2000); M - Diaixis (Ferrari, Markhaseva, 1996); N - Tharybis minor (Schulz, 1981); O - Brachycalanus (Ferrari, Markhaseva, 2000b), Parkius (Ferrari, Markhaseva, 1996), Puchinia (holotype, original observations), Rythabis (Schulz in Schulz, Beckmann, 1995); P - Macandrewella (Ohtsuka et al. , 2002), Pseudoamallothrix (Vyshkvartzeva, 2000), Scolecithricella (Park, 1980), Scottocalanus (Park, 1983a); Scaphocalanus (Park, 1982), Scolecithrix (Park, 1983a); Q — Landrumius (Park 1983a). Simple line is a sclerotized seta; stippled enclosure is a worm-like seta; dark enclosure is a brush-like seta; number to left of syncoxal block indicates the number of transformations from praecoxal endites with 1,2,3 sclerotized setae, the condition which is ancestral for bradfordian genera.

Рис. 29. Тип вооружения прекоксальных эндитов синкоксы максиллипеды для различных родов «брэдфордовских» семейств (в каждом роде выбирался наиболее примитивный тип вооружения из известных для рода, источник информации указан в скобках):

A - Brodskius (here); B - Undinella (von Vaupel Klein, 1970); C - Grievella (Ferrari, Markhaseva, 2000c), Tharybis (Ferrari, Markhaseva, 2005); D - Phaennocalanus (Markhaseva, 2002); E - Archescolecithrix (Vyshkvartzeva, 1989a), Omorius (here); F - Byrathis (here); G - Falsilandrumius (Vyshkvartzeva, 2001), Xantharus (Schulz 1998); H - Cephalophanes (Park, 1983b), Cornucalanus (Park, 1983b), Onchocalanus (Park, 1983b), Phaenna (Park, 1983b), Talacalanus (Park 1983b for Xanthocalanus greeni), Xanthocalanus (Markhaseva, 1998); I - Amallothrix (Park, 1970 for Scolecithricella lobophora), Lophothrix (Park, 1983a), Mixtocalanus (Vyshkvartzeva, 1989a), Racovitzanus (Park, 1983a),Scopalatum (Ferrari, Steinberg, 1993); J - Cenognatha (Hulsemann, 1985),Neoscolecithrix (Bradford-Grieve, 2001); K-Plesioscolecithrix(Markhaseva, Dahms, 2004); L - Parascaphocalanus(Vyshkvartzeva, 2001), Scolecitrichopsis (Vyshkvartzeva, 2000); M - Diaixis (Ferrari, Markhaseva, 1996); N - Tharybis minor (Schulz, 1981); O - Brachycalanus (Ferrari, Markhaseva, 2000b), Parkius (Ferrari, Markhaseva, 1996), Puchinia (holotype, original observations), Rythabis (Schulz in Schulz, Beckmann, 1995); P - Macandrewella (Ohtsuka et al., 2002), Pseudoamallothrix (Vyshkvartzeva, 2000), Scolecithricella (Park, 1980), Scottocalanus (Park, 1983a); Scaphocalanus (Park, 1982), Scolecithrix (Park, 1983a); Q — Landrumius (Park 1983a). Непрерывной линией обозначена склеротизированная щетинка; заштрихованной червевидная сенсорная щетинка; залитой черным кисточковидная сенсорная щетинка. Цифры слева от изображений синкоксы обозначают число преобразований щетинок прекоксальных эндитов максиллипеды от наиболее примитивного для группы родов «брэдфордовских» семейств типа (1, 2, 3 склеротизированные щетинки). 
A

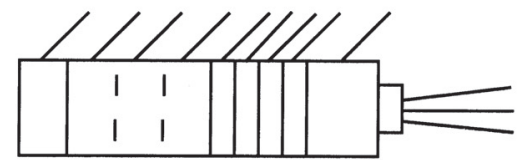

$1,1-1-1,1,1,1,1,1,3$

C

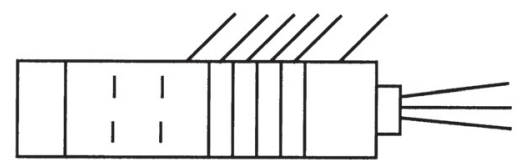

0,0 - 0 - 1, 1,1,1,1,1, 3

$\mathrm{E}$

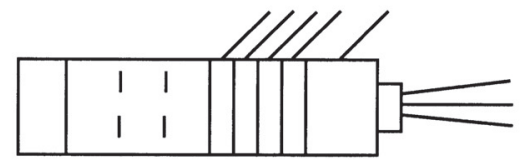

$0,0-0-0,1,1,1,1,1,3$
B

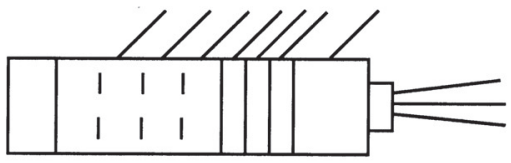

$0,0-1$ - 1 - 1,1,1,1, 1, 3

D

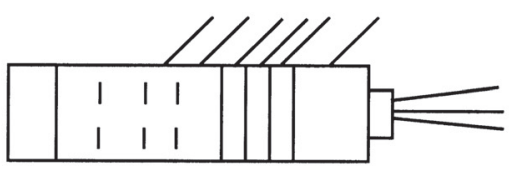

0,0 - 0 - 1 - 1,1,1,1,1,3

F

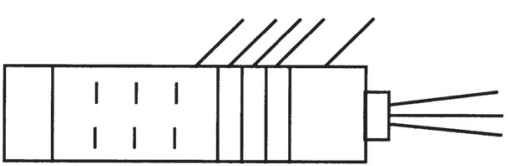

0,0 - 0 - 0 - 1,1,1,1,1, 3

Fig. 30. Ancestral condition of setation and segmentation of exopod of antenna 2 for various bradfordian genera; sources as for Fig. 29:

A - Puchinia*, Omorius, Neoscolecithrix, Byrathis, Cenognatha, Diaixis; B - Grievella; C - Amallothrix, Brachycalanus, Macandrewella, Parascaphocalanus, Pseudoamallothrix, Scaphocalanus, Scopalatum, Scolecithricella, Scottocalanus, Xantharus; D - Archescolecithrix, Falsilandrumius, Mixtocalanus, Onchocalanus, Scolecithrix*, Racovitzanus; E - Tharybis, Talacalanus, Xanthocalanus, Plesioscolecithrix, Scolecithrichopsis, Undinella; F Phaennocalanus, Landrumius, Phaenna, Cephalophanes, Cornucalanus, Rythabis, Parkius, Lophothrix*, Brodskius. (* seta may be absent on long (penultimate) segment). Proximal segment is on the left followed by the long segment, which is a complex; the elongate penultimate segment is adjacent to the distal segment which is on the right. Simple line is a sclerotized seta, two vertical dashes indicates position of an arthrodial membrane which has failed to form; number sequence below drawing indicates setae present on ancestral segments, comma represents an arthrodial membrane, dash represents absence of an arthrodial membrane.

Рис. 30. Тип вооружения экзоподита антенны 2 для различных родов «брэдфордовских» семейств (в каждом роде выбирался наиболее примитивный тип вооружения из известных для рода, источники информации те же, что и для рисунка 29):

A - Puchinia*, Omorius, Neoscolecithrix, Byrathis, Cenognatha, Diaixis; B - Grievella; C - Amallothrix, Brachycalanus, Macandrewella, Parascaphocalanus, Pseudoamallothrix, Scaphocalanus, Scopalatum, Scolecithricella, Scottocalanus, Xantharus; D - Archescolecithrix, Falsilandrumius, Mixtocalanus, Onchocalanus, Scolecithrix*, Racovitzanus; E - Tharybis, Talacalanus, Xanthocalanus, Plesioscolecithrix, Scolecithrichopsis, Undinella; F Phaennocalanus, Landrumius, Phaenna, Cephalophanes, Cornucalanus, Rythabis, Parkius, Lophothrix*, Brodskius. (* щетинка может отсутствовать на длинном (предпоследнем) членике). Проксимальный членик - крайний слева, за ним следует длинный членик, который является комплексом члеников; за длинным предпоследним члеником следует дистальный членик (справа). Непрерывной линией обозначена склеротизированная щетинка, пунктир обозначает место несформировавшейся межсегментной перегородки. Последовательность чисел под каждым изображением обозначает щетинки соответствующего анцестрального членика, запятая обозначает наличие межсегментной перегородки, тире обозначает отсутствие межсегментной перегородки. 
number of transformations among extant bradfordian species. Loss of either a sclerotized seta or a worm-like seta from the distal endite of the basis, resulting in eight setae, is assumed to have occurred early in the evolution of the group. Failure of formation of any seta is equivalent to a single transformation step; however, a sclerotized seta or a worm-like chemosensory seta is much more likely to fail to form than is a brush-like seta due to the latter's greater complexity (Nishida, Ohtsuka, 1997).

In the following analysis, the least derived condition is assigned to a genus exhibiting variable states of any character. For example, three different states for the exopod of antenna 2 of Byrathis are described above: 1, 1-1-1, 1, 1, 1, $1,1,3 ; 1,1-1-1-1,1,1,1,1,3 ; 1,1-1-1,1-1,1$, $1,1,3$. The first state in which seven arthrodial membranes are present is considered the state of the ancestral Byrathis. In addition, transformations of sclerotized setae on the praecoxal endites of the maxilliped are assumed to precede changes to the exopod of antenna 2 in all cases. Changes to individual setae of the distal basal endite and ramus of maxilla 2 are assumed to have been the last to occur during the evolutionary history of bradfordian species.

Loss of one sclerotized seta to the distal praecoxal endite of the maxilliped, followed by the loss of a second sclerotized seta to the same endite results in an ancestral group and two major derived lineages (Fig. 31). The ancestral group retains 1,2, 3 setae, respectively, on the proximal, middle and distal praecoxal endites. Byrathis, Diaixis, Xantharus, Falsilandrumius, Landrumius, Neoscolecithrix and Cenognatha share a sensory seta on the distal praecoxal endite of the maxilliped. Grievella and Tharybis are without a seta on the proximal segment and a proximal seta on the long segment complex of the exopod of antenna 2. Brodskius is derived by loss of the seta on the proximal praecoxal endite of the maxilliped.

Most genera of the first monophyletic lineage, with 1,2, 2 setae on the praecoxal endites of the syncoxa of the maxilliped, previously have been placed in the family Phaennidae. Phaennocalanus retains a sclerotized setae on all praecoxal endites; the remaining genera share a brush-like seta on the distal praecoxal endite. Plesioscolecithrix, Puchinia, Brachycalanus, Rythabis, and Parkius share a worm-like seta on the middle praecoxal endite of the maxilliped. Cornucalanus, Onchocalanus, Phaenna, Cephalophanes, Talacalanus and Xanthocalanus, share a derived antennal 2 exopod but are incompletely resolved. It should be pointed out that Xanthocalanus consists of almost 50 nominal species, of which many are poorly described. When the genus is revised, some species will be placed in known genera, including Brachycalanus, while other species undoubtedly will have new genera established for them. Undinella is derived by loss of the seta on the proximal praecoxal endite of the maxilliped.

Genera of the second monophyletic lineage, with 1,2,1 setae on the praecoxal endites of the syncoxa of the maxilliped, have been placed in the Scolecitrichidae, with the exception of the new genus Omorius. Omorius and Archescolecithrix retain sclerotized setae on the praecoxal endites of the maxilliped; all other genera share a brush-like seta on the distal praecoxal endite. A worm-like seta on the middle praecoxal endite, pre-sumably homologous to that of the first lineage, separates Parascaphocalanus, Scolecithrix, Scolecitrichopsis, Scaphocalanus, Scolecithricella, Scottocalanus, Macandrewella and Pseudoamallothrix from Amallothrix, Scopalatum, Mixtocalanus, Racovitzanus, and Lophothrix.

The ancestral group and both derived lineages have genera without transformed setae on the praecoxal endites of the maxilliped: Grievella with 1, 2, 3 sclerotized setae; Phaennocalanus with 1, 2, 2 sclerotized setae; Archescolecithrix and Omorius with 1,2,1 sclerotized setae. In the ancestral group Grievella, Xantharus, Tharybis, Landrumius, Falsilandrumius, and Neoscolecithrix retain the primitive state of nine setae on the distal basal endite plus ramus of maxilla 2 . In the first derived lineage some species of Brachycalanus retain nine setae on the distal basal endite plus ramus of maxilla 2. No genus in the second derived lineage retains nine setae on the distal basal endite plus ramus of maxilla 2 . Five 


\begin{tabular}{|c|c|c|c|c|c|c|c|c|}
\hline 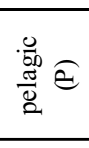 & 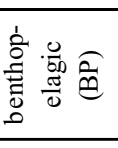 & $\ddot{m}$ & $\tilde{\bar{n}}$ & $\tilde{m}$ & a & $\begin{array}{l}\tilde{m} \\
\text { si }\end{array}$ & $a$ & \\
\hline & 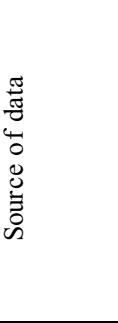 & 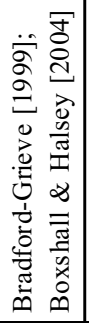 & 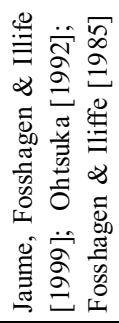 & 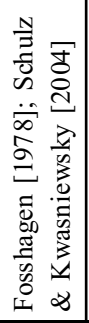 & 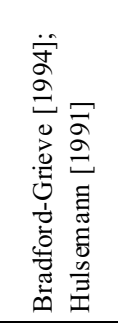 & 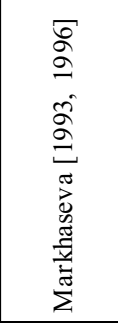 & 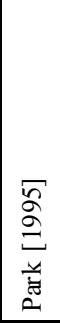 & \\
\hline & & $\sigma$ & 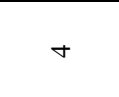 & 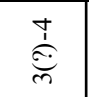 & 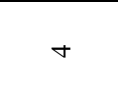 & $\nabla$ & $m$ & $\theta$ \\
\hline & 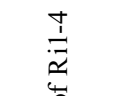 & $\tilde{i}$ & $m$ & $\stackrel{?}{\stackrel{\tilde{U}}{\tilde{d}}}$ & $m$ & $m$ & N & $m$ \\
\hline 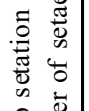 & 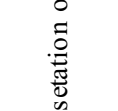 & $\nabla$ & $\stackrel{+}{\stackrel{\leftrightarrow}{\leftrightarrow}}$ & 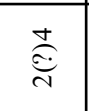 & $\checkmark$ & 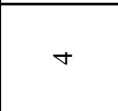 & m & $\theta$ \\
\hline 胥 & & $\nabla$ & 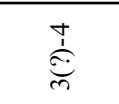 & 萨 & $\sigma$ & + & $\nabla$ & $\theta$ \\
\hline & 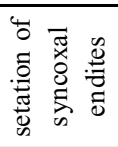 & 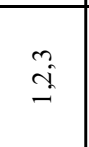 & 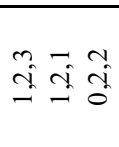 & $\begin{array}{ll}\Rightarrow & m \\
0 & 0\end{array}$ & $\stackrel{m}{\underline{i}}$ & $\stackrel{m}{i}$ & $\stackrel{m}{\stackrel{m}{-}}$ & $\stackrel{m}{\stackrel{m}{i}}$ \\
\hline 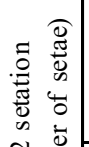 & 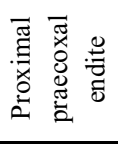 & $\stackrel{0}{m}$ & $\begin{array}{l}0 \\
+ \\
+\end{array}$ & in & $\frac{n}{m}$ & $m$ & $n$ & 0 \\
\hline 艾兽 & $\approx \underset{\tilde{d}}{\tilde{d}} \#$ & $\begin{array}{l}n \\
\mathfrak{a} \\
\pm \\
\end{array}$ & 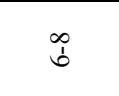 & in & \pm & in & 0 & $a$ \\
\hline & $\approx$ & $=$ & $\begin{array}{l}\infty \\
b \\
b\end{array}$ & $\infty$ & $=$ & 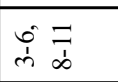 & $=$ & $=$ \\
\hline & $\ddot{\approx}$ & $\begin{array}{l}0 \\
\\
\dot{I}\end{array}$ & $\stackrel{I}{\Xi}$ & $\therefore$ & $\stackrel{0}{0}$ & $\dot{m} \sim \frac{0}{=}$ & $\frac{\circ}{9}$ & $\stackrel{0}{-}$ \\
\hline 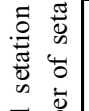 & 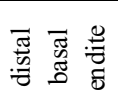 & in & in & 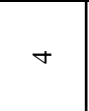 & in & $\ddot{\sim}$ & $\begin{array}{l}0 \\
\dot{m}\end{array}$ & 0 \\
\hline 齐壹 & 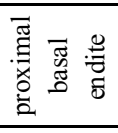 & + & $m$ & $\hat{i}$ & $\sigma$ & 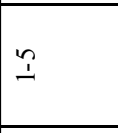 & - & in \\
\hline & 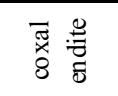 & $m$ & $\dot{\sim}$ & $\stackrel{m}{\sim}$ & in & $\stackrel{n}{i}$ & ֻ̃ & in \\
\hline & 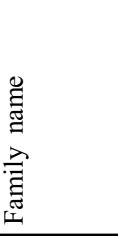 & 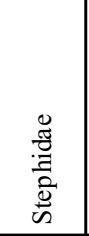 & 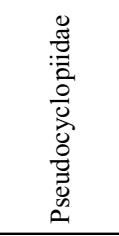 & 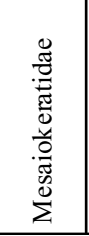 & 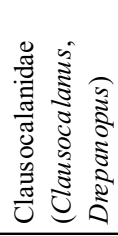 & 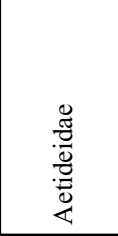 & 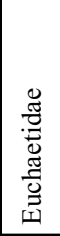 & 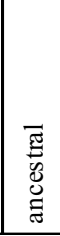 \\
\hline
\end{tabular}


worm-like setae on the distal basal endite plus ramus of maxilla 2 are retained by Brodskius, Byrathis, Neoscolecithrix in the ancestral group, six worm-like setae by Rythabis in the first derived lineage and five by Omorius in the second derived lineage. Most genera of the first derived lineage are without setae on the three segments of the long segment complex of the exopod of antenna 2, while most genera of the second derived lineage retain the seta on the distal segment of the three segments of the long segment complex. Loss of the seta on the proximal praecoxal endite of the maxilliped of Brodskius and Undinella is unique to the lineages with three or two setae, respectively, on the distal praecoxal endite. This loss is assumed to have been independently derived.

Due to the paucity of characters, the above hypothesized relationships (Fig. 31) result in undefined lineages and unresolved groups of genera. However, if our hypothesis about relationships is correct, then different pelagic or benthopelagic ancestors to the genera comprising both families Phaennidae and Scolecitrichidae suggest these pelagic families are not their own closest relatives. A less derived ben- thopelagic genus is hypothesized for each family: Omorius for genera in the Scolecitrichidae; an early species of the ancestral group for genera in the Phaennidae (Fig. 31). This inference suggests that the invasion of the pelagic realm by bradfordian copepods has occurred more than once after the colonization of benthopelagic habitats by a tharybid-like bradfordian ancestor (Bradford-Grieve, 2004).

The results of this analysis are considered preliminary because assumptions about the transformations of character states and the order of transformation of different characters have yet to be applied to many bradfordian genera. Assignment to families of the three new genera remains tentative. Byrathis belongs to lineage, with Diaixis, Xantharus, Falsilandrumius, Landrumius, Neoscolecithrix and Cenognatha, in which one of three setae on the distal praecoxal endite of the maxilliped has been transformed to a sensory seta; Diaixidae is available for this lineage. Brodskius belongs to a lineage with Grievella and Tharybis in which setae on the two proximal segments of the exopod of antenna 2 fail to form; Tharybidae is available for this lineage. Omorius

Fig. 31. Relationships among some bradfordian genera based on: number and type of setae on praecoxal endites of the maxilliped; setation of five ancestral segments of the exopod of antenna 2; number and kinds of setae on the distal basal endite plus ramus of maxilla 2. Sequence of three numbers separated by periods are number of setae on the proximal, middle and distal praecoxal endites of the maxilliped syncoxa ( $\mathrm{w}=$ worm-like seta; $b=$ brush-like seta; sclerotized seta as a simple number); sequence of five numbers separated by commas (arthrodial membrane present) and dashes (arthrodial membrane absent) are segment/seta on the proximal five ancestral segments of the exopod of antenna 2; sequence of three numbers separated by commas are the number of sclerotized, worm-like, brush-like setae on the distal basal endite plus ramus of maxilla 2.

Рис. 31. Родственные связи между некоторыми родами «брэдфордовских» семейств. Для анализа использованы следующие признаки: число и тип щетинок на прекоксальных эндитах синкоксы максиллипеды; вооружение пяти анцестральных сегментов экзоподита антенны 2; число и тип щетинок на дистальном базальном эндите и ветви максиллы 2. Последовательность из трех цифр, разделенных точкой, соответствует числу щетинок на проксимальном, среднем и дистальном эндитах синкоксы максиллипеды ( $\mathrm{w}=$ червевидная сенсорная щетинка; $\mathrm{b}=$ кисточковидная сенсорная щетинка, если щетинка склеротизированная - обозначена просто цифрой). Последовательность из пяти цифр, разделенных запятыми (межсегментная перегородка присутствует) и тире (межсегментная перегородка отсутствует), является последовательностью сегментов/щетинок пяти проксимальных анцестральных сегментов экзоподита антенны 2. Последовательность из трех цифр, разделенных запятыми, является последовательностью числа склеротизированных, червевидных и кисточковидных щетинок на дистальном базальном эндите и ветви максиллы 2. 


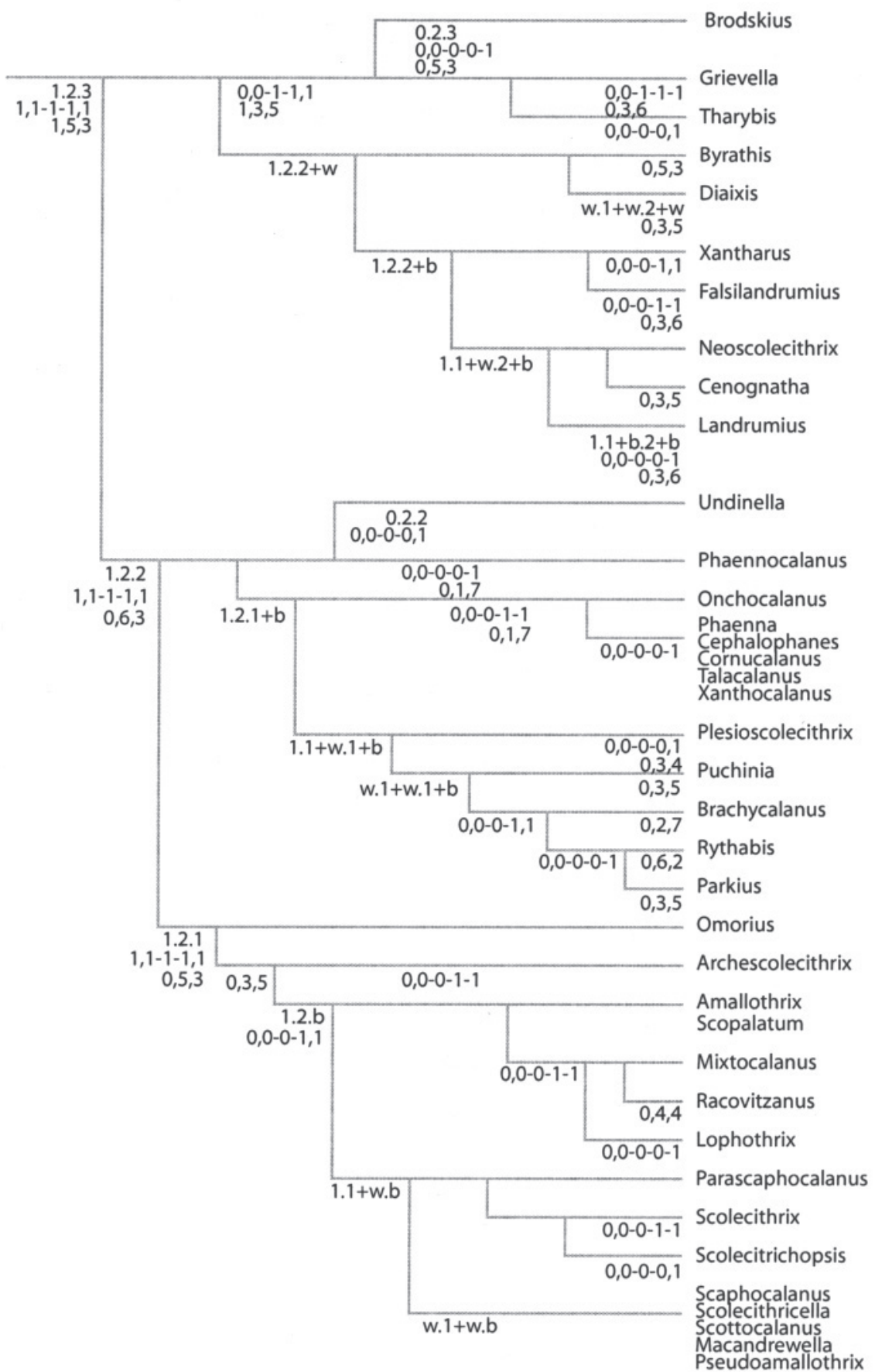


may be placed in the family Scolecitrichidae as diagnosed with 1, 2, 1 setae on the praecoxal endites of the maxilliped.

Among bradfordian species and genera, parallel transformations of apparently homologous maxilliped syncoxal sclerotized setae into poorly-sclerotized setae provide examples of Vavilov's Law (1920) that related species may express a similar variation in derived homologous structures (ref. after Vavilov, 1966). Tharybis inaequalis Bradford-Grieve, 2001 shares with Byrathis a transformed worm-like seta on the distal praecoxal endite of maxilliped (Fig. 29F); T. crenata Schulz, 1995 and T. angularis Schulz, 1995 share with Xantharus and Falsilandrumius a transformed brush-like seta on the distal praecoxal endite (Fig. 29G); T. shuheiella Ferrari, Markhaseva, 2005 shares with Diaixis (Fig. 29M) one transformed worm-like seta each on the proximal, middle and distal praecoxal endites of maxilliped; Neoscolecithrix and Cenognatha share with Plesioscolecithrix and with Parascaphocalanus and Scolecitrichopsis a worm-like seta on the middle praecoxal endite and a brush-like seta on the distal endite (Fig. 29J, K, L); T. minor Schulz, 1981 shares with Brachycalanus, Parkius, Puchinia and Rythabis, and with Macandrewella, Pseudoamallothrix, Scolecithricella, Scottocalanus, Scaphocalanus and Scolecithrix a worm-like setae on the proximal and middle praecoxal endite, and a brush-like seta on the distal endite (Fig. 29 N, O, P).

If the number of setae on each of three praecoxal endites of the maxilliped determines early branching, a modest number of convergences results for states of the exopod of antenna 2 , and a large number of convergences results for the number of worm-like plus brushlike setae on the distal basal endite plus ramus of maxilla 2. The convergences in states of the exopod of antenna 2 usually results from presence/absence of the arthrodial membrane between the long segment and the proximal of four small segments. Careful observations of segmentation and setation of the exopod may reduce the number of these convergences. The same cannot be said for the number of worm- like plus brush-like setae on the distal basal endite plus ramus of maxilla 2 because determining homologies of these individual setae seems beyond the limits of contemporary optical microscopy.

Detailed descriptions of mandible, maxilla 1 and swimming leg 1 hold promise as informative states of bradfordian genera. Knobs or bumps on the distal and posterior faces of the mandible, and differences in numbers of setae or presence/ absence of arthrodial membranes on maxilla 1 have proven useful in diagnosing genera. Von Vaupel Klein's organ on swimming leg 1 also may help resolve relationships among bradfordian genera. Von Vaupel Klein's organ, synapomorphy of gymnoplean copepods, is a transformation of the medial seta of the basis and the anterior face of the proximal endopodal segment which bears one medial seta. Calanoids with a 2or 3-segmented endopod also usually express Von Vaupel Klein's organ (e.g. see Ferrari (1995) for Ridgewayia klausruetzleri Ferrari, 1995). A copepod like Acrocalanus gibber Giesbrecht, 1888 , with a 2-segmented endopod, is missing the middle segment of a copepod with a 3segmented endopod (unpublished observations of development), so the proximal segment remains. A copepod with an apparently 1-segmented endopod, like the clausocalanoideans, actually is missing only the distal arthrodial membrane between both segments of a 2-segmented endopod. So the clausocalanoidean endopod is not truly 1-segmented, but rather a 2-segmented complex with the arthrodial membrane between the two segments missing. Here, our inability to determine how the different states of Von Vaupel Klein's organ have been transformed among the various bradfordian calanoids precluded its use in our analysis. A better understanding of the diversity of Von Vaupel Klein's organ, including optical, scanning and transmission electron microscopy, may provide better insights.

\section{Acknowledgements}

Dr. Karen F. Wishner, University of Rhode Island, Dr. Edward J. Buskey, University of Texas at Austin, and Dr. Lauren S. Mullineaux, 
Woods Hole Oceanographic Institution kindly donated specimens. Ms Lana Ong and Ms Molly Ryan prepared the computer layout of the illustrations. ELM was supported by the Smithsonian Institution's Short-Term Visitor Program and the American Philosophical Society.

\section{Literature Cited}

Andronov V. N. 1981. [Xantharus formosus gen. et sp.n (Copepoda, Calanoida) from the north-west Atlantic] // Zoologicheskii Zhurnal. Vol.60. P.1719-1722 [in Russian].

Andronov V.N. 2002. [The calanoid copepods (Crustacea) of the genera Diaixis Sars, 1902, Parundinella Fleminger, 1957, Undinella Sars 1900 and Tharybis Sars, 1902] // Arthropoda Selecta. Vol.11. No.1. P.1-80 [in Russian with extensive English summary].

Boxshall G.A., Halsey S.H. 2004. An Introduction to Copepod Diversity. Part I // London: The Ray Society. 421 p.

Bradford J.M. 1973. Revision of family and some generic definitions in the Phaennidae and Scolecithricidae (Copepoda: Calanoida) // New Zealand Journal of Marine and Freshwater Research. Vol.7. P.133-152.

Bradford J.M., Haakonssen L., Jillett J.B. 1983. The marine fauna of New Zealand: pelagic calanoid copepods: families Euchaetidae, Phaennidae, Scolecithricidae, Diaixidae, and Tharybidae // Memoirs of the New Zealand Oceanographic Institute. No.90. 150 p.

Bradford-Grieve J.M. 1994. Pelagic calanoid Copepoda: Megacalanidae, Calanidae, Paracalanidae, Mecynoceridae, Eucalanidae, Spinocalanidae, Clausocalanidae // New Zealand Oceanographic Institute Memoir. No.102. 159 p.

Bradford-Grieve J.M. 1999. New species of benthopelagic copepods of the genus Stephos (Calanoida: Stephidae) from Wellington Harbour, New Zealand//New Zealand Journal of Marine and Freshwater Research Vol.33. P.13-27.

Bradford-Grieve J.M. 2001. Two species of benthopelagic calanoid copepods of the genus Neoscolecithrix Canu, 1896 s.s. from New Zealand and the segregation of Cenognatha $\mathrm{n}$. gen. // New Zealand Journal of Marine and Freshwater Research. Vol.35. P.781-793.

Bradford-Grieve J.M. 2004. Deep-sea benthopelagic calanoid copepods and their colonization of the nearbottom environment // Zoological Studies. Vol.43. P. 276-291.

Canu, E. 1896. Resultats Scientifiques de la Campagne du «Caudan» dans le Golfe de Gascogne - Aout-Septembre 1895 - par R. Koehler. Copepodes // Annales de l’Université de Lyon. Vol.26. P.421-437. pl.18.

Dogiel V.A. 1954. [Oligomerization of homologous organs as one of the main paths in animal evolution] // St. Petersburg: Leningrad University Press. 368 p. [in Russian].

Ferrari F.D. 1995. Six copepodid stages of Ridgewayia klausruetzleri, a new species of calanoid copepod
(Ridgewayiidae) from the barrier reef in Belize, with comments on appendage development // Proceedings of the Biological Society of Washington. Vol.108. P.180-200.

Ferrari F.D., Markhaseva E.L. 1996. Parkius karenwishnerae, a new genus and species of calanoid copepod (Parkiidae, new family) from benthopelagic waters of the eastern tropical Pacific Ocean // Proceedings of the Biological Society of Washington. Vol.109. P.264-285.

Ferrari F.D., Ivanenko V.N. 2001. Interpreting segment homologies of the maxilliped of cyclopoid copepods by comparing stage-specific changes during development // Organisms, Diversity and Evolution. Vol.1. P.113-131.

Ferrari F.D., Markhaseva E.L. 2000a. Griceus buskeyi, a new genus and species of calanoid copepod (Crustacea) from benthopelagic waters off Hawaii // Proceedings of the Biological Society of Washington. Vol.113. P.78-88.

Ferrari F.D., Markhaseva E.L. 2000b.Brachycalanus flemingeri and $B$. brodskyi, two new copepods (Crustacea: Calanoida: Phaennidae) from benthopelagic waters of the tropical Pacific // Proceedings of the Biological Society of Washington. Vol.113. P.1064-1078.

Ferrari F.D., Markhaseva E.L. 2000c. Grievella shanki, a new genus and species of scolecitrichid calanoid copepod (Crustacea) from a hydrothermal vent along the southern East Pacific Rise // Proceedings of the Biological Society of Washington. Vol.113. P.1079-1088.

Ferrari F.D., Markhaseva E.L. 2005. Three new species of Tharybis (Crustacea: Copepoda: Calanoida: Tharybidae) from benthopelagic waters of the Pacific Ocean // Plankton Biology and Ecology. Vol.52. P.33-47.

Ferrari F.D., Steinberg D. 1993. Scopalatum vorax (Esterly, 1911) and Scolecithricella lobophora Park, 1970 calanoid copepods (Scolecitrichidae) associated with a pelagic tunicate in Monterey Bay // Proceedings of the Biological Society of Washington. Vol.106. P.467-489.

Fosshagen A. 1978. Mesaiokeras (Copepoda, Calanoida) from Colombia and Norway // Sarsia. Vol.63. P.117-183.

Fosshagen A., Iliffe T.M. 1985. Two new genera of Calanoida and a new order of Copepoda, Platycopioida, from Marine caves on Bermuda // Sarsia. Vol.70. P.345-358.

Fleminger A. 1957. New genus and two new species of Tharybidae (Copepoda Calanoida) from the Gulf of Mexico with remarks on the status of the family // Fishery Bulletin of the United States National Marine Fisheries Service. Vol.116. P.347-354.

Friedman M.M., Strickler J.R. 1975. Chemoreceptors and feeding in calanoid copepods (Arthropoda: Crustacea) // Proceedings of the National Academy of Sciences of the United States of America. Vol.72. P. 4185-4188.

Giesbrecht W. 1892. Systematik und Faunistik der pelagischen Copepoden des Golfes von Neapel und der angrenzenden Meeres-Abschnitte // Fauna und Flora 
des Golfes von Neapel und der Angrenzenden MeeresAbschnitte. Herausgegeben von der Zoologischen Station zu Neapel. No.19. P.1-831. pls.1-54.

Grice G.D., Hulsemann K. 1965. Abundance, vertical distribution and taxonomy of calanoid copepods at selected stations in the north-east Atlantic // Journal of Zoology. London. Vol.146. P.213-262.

Grice G.D., Hulsemann K. 1967. Bathypelagic calanoid copepods of the western Indian Ocean // Proceedings of the United States National Museum. No.1223. P.1-67.

Grice G.D., Hulsemann K. 1970. New species of bottomliving calanoid copepods collected in deep water by the DSRV "Alvin" // Bulletin of the Museum of Comparative Zoology. Vol.139. P.185-230.

Hulsemann K. 1985. New species of Neoscolecithrix Canu (Copepoda Calanoida) in Antarctic waters with remarks on the genus // Polar Biology. Vol.5. P.55-62.

Hulsemann K. 1991. The copepodid stages of Drepanopus forcipatus Giesbrecht, with notes on the genus and a comparison with other members of the family Clausocalanidae (Copepoda Calanoida) // Helgolander Meeresuntersuchungen. Vol.45. P.199-224.

Jaume D., Fosshagen A., Iliffe T.M. 1999. New cavedwelling pseudocyclopiids (Copepoda, Calanoida, Pseudocyclopiidae) from Balearic, Canary, and Philippine archipelagos // Sarsia. Vol.84. P.391-417.

Markhaseva E.L. 1993. [Evolutionary trends within Aetideidae (Copepoda, Calanoida)] // Issledovanija fauny morei. Vol.45. P.51-69 [in Russian with English summary].

Markhaseva E.L. 1996. Calanoid copepods of the family Aetideidae of the world ocean // Trudy Zoologicheskogo Instituta RAN. Vol.268. P.1-331.

Markhaseva E.L. 1998. New species of the genus Xanthocalanus (Copepoda, Calanoida, Phaennidae) from the Laptev Sea // Journal of Marine Systems. Spec. Vol.15. P.413-419.

Markhaseva E.L. 2002. Phaennocalanus unispinosus (Copepoda, Calanoida, Phaennidae): new genus and new species from the bathypelagial Arctic Basin $/ /$ Sarsia. Vol.87. P.312-318.

Markhaseva E.L., Dahms H.-U. 2004. Plesioscolecithrix (Copepoda, Calanoida, Scolecitrichidae): new genus and new species from the high Antarctic Weddell Sea (Southern Ocean) // Sarsia. Vol.89. P.326-337.

Markhaseva E.L., Schnack-Schiel S.B. 2003. New and rare calanoid copepods from the Great Meteor Seamount, northeastern Atlantic // Ophelia. Vol.57. P.107-123.

Mullineaux L.S., Mills S.W., Sweetman A.K., Beaudreau A.H., Metaxas A., Hunt H.L. 2005. Spatial structure and temporal variation in larval abundance at hydrothermal vents on the East Pacific Rise // Marine Ecology Progress Series (in press).

Nishida S., Ohtsuka S. 1997. Ultrastructure of the mouthpart sensory setae in mesopelagic copepods of the family Scolecitrichidae // Plankton Biology and Ecology. Vol.44. P.81-90.

Ohtsuka S. 1992. Calanoid copepods collected from the near bottom in Tanabe Bay on the Pacific coast of the middle Honshu, Japan. IV. Pseudocyclopiidae // Publications of the Seto Marine Biological Laboratory. Vol.35. P.295-301.

Ohtsuka S., Boxshall, G.A., Fosshagen, A. 2003. A new species of Neoscolecithrix (Crustacea; Copepoda; Calanoida) from off Okinawa, southwestern Japan, with comments on the generic position in the superfamily Clausocalanoidea // Bulletin of the National Science Museum. Ser. A. Vol.29. P.53-63.

Ohtsuka S., Nishida S., Nakaguchi K. 2002. Three new species of the genusMacandrewella (Copepoda: Calanoida: Scolecitrichidae) from the Pacific Ocean, with notes on distribution and feeding habits // Journal of Natural History. Vol.36. P.531-564.

Ohtsuka S., Takeuchi I., Tanimura A. 1998. Xanthocalanus gracilis and Tharybis magna (Copepoda: Calanoida) rediscovered from the Antarctic Ocean with baited traps // Journal of Natural History. Vol.32. P.785-804.

Paffenhofer G.A., Loyd P.A. 1999. Ultrastructure of setae of the maxilliped of the marine planktonic copepod Temora stylifera // Marine Ecology Progress Series. Vol.178. P.101-107.

Paffenhofer G.A., Loyd P.A. 2000. Ultrastructure of cephalic appendage setae of marine planktonic copepods // Marine Ecology Progress Series. Vol.203. P. 171-180

Park T.S. 1970. Calanoid copepods from the Carribbean Sea and Gulf of Mexico. 2. New species and new records from plankton samples // Bulletin of Marine Sciences. Vol.20. P.472-546.

Park T. 1978. Calanoid copepods belonging to the families Aetideidae and Euchaetidae from Antarctic and Subantarctic Waters // Antarctic Research Series. Vol.27. P.91-290.

Park, T. 1980. Calanoid copepods of the genus Scolecithricella from antarctic and subantarctic waters // Antarctic Research Series. Vol.31. P.25-79.

Park, T. 1982. Calanoid copepods of the genus Scaphocalanus from antarctic and subantarctic waters // Antarctic Research Series. Vol.34. P.75-127.

Park T. 1983a. Calanoid copepods of some scolecithricid genera from antarctic and subantarctic waters // Antarctic Research Series. Vol.38. P.165-213.

Park T. 1983b. Calanoid copepods of the family Phaennidae from antarctic and subantarctic waters // Antarctic Research Series. Vol.39. P.317-368.

Park T. 1995. Taxonomy and distribution of the marine calanoid copepod Family Euchaetidae // Bulletin of the Scripps Institution of Oceanography, University of California. No.29. 203 p.

Roe H.S.J. 1975. Some new and rare species of calanoid copepods from the northeastern Atlantic// Bulletin of the British Museum of Natural History. Zoology. Vol.28. P.295-372.

Sars G.O. 1902. Copepoda Calanoida, Parts V, VI, Scolecithricidae, Stephidae, Tharybidae, Pseudocyclopiidae // An Account of the Crustacea of Norway, with short descriptions and figures of all the species, Bergen Museum. 4. P.49-72. pls.33-48. 
Schulz K. 1981. Tharybis minor sp.n. (Copepoda: Calanoida: Tharybidae) aus dem nordwestafrikanischen Auftriebsgebiet mit Anmerkungen zur Gattung Tharybis Sars // Mitteilungen aus dem Hamburgischen Zoologischen Museum und Institut. Vol.78. P.169177.

Schulz K. 1996. Frigocalanus rauscherti, a new genus and species of hyperbenthic copepod (Calanoida: Clausocalanoidea) from the sublittoral of King George Island (Antarctica) // Mitteilungen aus dem hamburgischen zoologischen Museum und Institut. Vol.93. P.73-82.

Schulz K. 1998. A new species of Xantharus Andronov, 1981 (Copepoda: Calanoida) from the mesopelagic zone of the Antarctic Ocean // Helgolander Meeresuntersuchungen. Vol.52. P.41-49.

Schulz K., Beckmann W. 1995. New benthopelagic tharybids (Copepoda: Calanoida) from the deep North Atlantic // Sarsia. Vol.80. P.199-211.

Schulz K., Markhaseva E.L. 2000. Parabradyidius angelikae, a new genus and species of benthopelagic copepod (Calanoida: Aetideidae) from the deep Weddell Sea (Antarctica) // Mitteilungen aus dem Hamburgischen Zoologischen Museum und Institut. Vol.97. P.77-89.

Schulz K., Kwasniewsky S. 2004. New species of benthopelagic calanoid copepods from Kongsfjorden (Spitsbergen, Svalbard Archipelago)// Sarsia. Vol.89. P.143-159.

Seifried S. 2003. Phylogeny of Harpacticoida (Copepoda) Revision of "Maxillipedasphalea" and Exanechentera. Goettingen: Cuvillier Verlag. 259 p.
Vaupel Klein J.C. von. 1970. Notes on a small collection of calanoid copepods from the northeastern Pacific, including the description of a new species of Undinella (Fam. Tharybidae) // Zoologische Verhandelingen. Vol.110. P.1-43.

Vaupel Klein J.C.von, Rijerkerk C.D.M. 1997. A detailed redescription of the Pseudochirella obesa female (Copepoda, Calanoida). 2. Antennae and mouthparts // Crustaceana. Vol.70. P.394-417.

Vavilov N. I. 1966. [Law of homologous rows in inheritance] // Academician N.I. Vavilov. Selected Publications: Genetics and Selection. Moscow: Kolos. P.5797 [in Russian].

Vyshkvartzeva N.V. 1989a. [On the systematics of the family Scolecithricidae (Copepoda, Calanoida): New genus Archescolecithrix and redescription of the genus Mixtocalanus Brodsky, 1950] // Issledovaniya Fauny Morei. Vol.41. P.5-23 [in Russian].

Vyshkvartzeva N.V. 1989b. [Puchinia obtusa gen. et sp.n. (Copepoda, Calanoida) from the ultra-abyssal of the Kuril-Kamchatska Trench and the place of the genus in the family Scolecithricidae] // Zoologicheskii Zhurnal. Vol.68. P.29-38 [in Russian].

Vyshkvartzeva N.V. 2000. Two new genera of Scolecitrichidae and redefinition of Scolecithricella Sars and Amallothrix Sars (Copepoda, Calanoida) // Zoosystematica Rossica. Vol.8. P.217-241.

Vyshkvartzeva N.V. 2001. A key to the genera of Scolecitrichidae, with description of a new genus and redescription of two species (Crustacea, Calanoida) // Zoosystematica Rossica. Vol.9. P.77-98. 